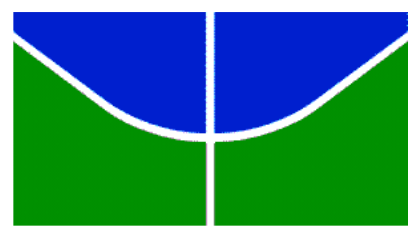

Universidade de Brasília

Instituto de Psicologia

Programa de Pós-Graduação em Processos de Desenvolvimento Humano e Saúde Área de Concentração: Desenvolvimento Humano e Cultura

ANÁLISES DOCENTES ACERCA DO PROCESSO HISTÓRICO DE INCLUSÃO DO ALUNO COM DEFICIÊNCIA INTELECTUAL NA REDE PÚBLICA DE ENSINO DO DISTRITO FEDERAL - OS ÚLTIMOS VINTE ANOS

Soraya Carvalho Pereira Rocha

Brasília-DF 


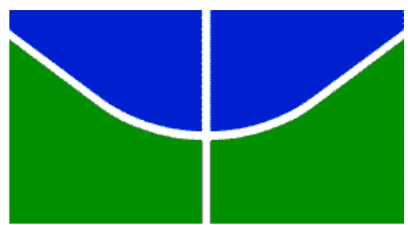

Universidade de Brasília

Instituto de Psicologia

Programa de Pós-Graduação em Processos de Desenvolvimento Humano e Saúde Área de Concentração: Desenvolvimento Humano e Cultura

\title{
ANÁLISES DOCENTES ACERCA DO PROCESSO HISTÓRICO DE INCLUSÃO DO ALUNO COM DEFICIÊNCIA INTELECTUAL NA REDE PÚBLICA DE ENSINO DO DISTRITO FEDERAL - OS ÚLTIMOS VINTE ANOS
}

\author{
Soraya Carvalho Pereira Rocha
}

Dissertação apresentada ao Instituto de Psicologia da Universidade de Brasília como requisito parcial à obtenção do título de Mestra em Processos e Desenvolvimento Humano e Saúde, na área de Desenvolvimento Humano e Cultura.

Orientadora: Profa. Dra. Daniele Nunes Henrique Silva

Brasília-DF

Março de 2017 
Ficha catalográfica elaborada automaticamente, com os dados fornecidos pelo(a) autor(a)

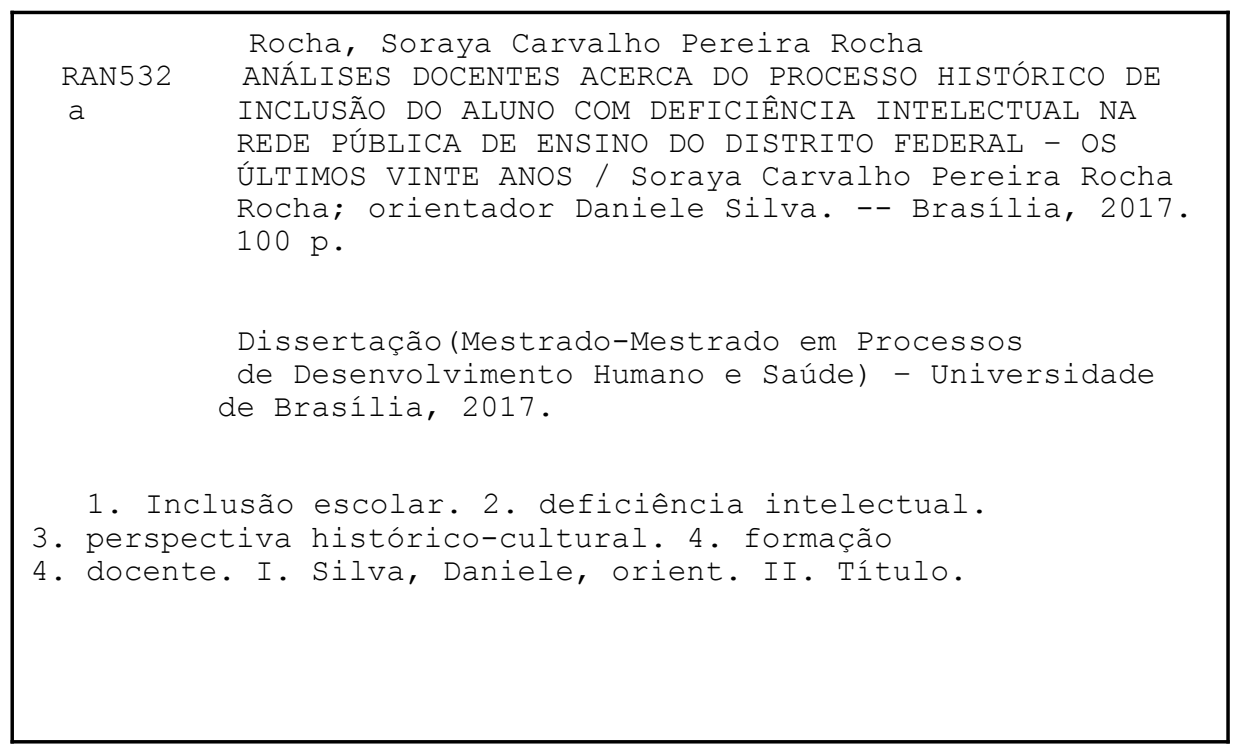


UNIVERSIDADE DE BRASÍLIA

INSTITUTO DE PSICOLOGIA

DISSERTAÇÃO DE MESTRADO APROVADA PELA SEGUINTE BANCA

EXAMINADORA:

Prof $^{\text {a }}$. Dr ${ }^{\text {a }}$. Daniele Nunes Henrique Silva - Presidente

Universidade de Brasília - UnB

Prof ${ }^{\text {a }}$. Dr ${ }^{\text {a }}$. Gabriela Sousa de Melo Mieto-Membro

Universidade de Brasília - UnB

Prof ${ }^{\text {a }}$. Dr ${ }^{\text {a }}$. Fátima Lucília Vidal Rodrigues- Membro

Universidade de Brasília - UnB

$\operatorname{Prof}^{a}{ }^{a}$ Dr ${ }^{\text {a }}$. Eva Aparecida Pereira Seabra da Cruz - Suplente

Pesquisadora GPPCULT

Brasília - DF

Março de 2017 


\section{Dedicatória}

Aos meus filhos Gabriella, Guilherme, Graziella, Giulliana e Giullia, e ao meu irmão Marcus Rodolfo pela dedicação, paciência e amor em todos os momentos desta trajetória. E à minha mãe (em memória), com muito carinho, dedico este mestrado com o qual, se ela estivesse presente, estaria muito feliz. 


\section{Agradecimentos}

Agradeço a Deus, que me deu a vida, o ânimo, a força e a saúde para oportunizar meu ingresso e minha caminhada neste mestrado.

Agradeço aos meus pais, Carmelita (em memória) e Ribamar, que me deram muito amor e proporcionaram estudos no intuito que me tornasse uma boa profissional.

Agradeço aos meus filhos Gabriella, Guilherme, Graziella, Giulliana e Giullia, que me incentivaram a querer estudar cada vez mais para poder dar condições melhores de vida a eles.

Agradeço a meu marido Silvio por ter paciência quando me ausentava para estudar.

Agradeço ao meu irmão Marcus Rodolfo por ter me incentivado a fazer a inscrição para seleção do mestrado, me ajudado tantas vezes a revisar o texto, auxiliando e orientando nos meus estudos; meu grande e amado amigo.

Agradeço aos meus queridos e amados irmãos José Ribamar Júnior, Ednaldo Júnior, Jubiraci e Ednailton, e as minhas cunhadas Marilza, Tatiane, Andrea e July pelo carinho e pela força que me deram nesta caminhada.

Agradeço à minha orientadora Daniele Nunes por ter me aceitado como sua orientanda, acreditado em mim nos momentos mais difíceis, por ter me orientado, ajudado e tornado possível realizar um sonho que há tanto tempo desejava, o qual era fazer o mestrado.

Agradeço aos professores do Programa de Pós-Graduação em Desenvolvimento Humano e Saúde que contribuíram para meu aprendizado durante a trajetória do mestrado, como Silviane Barbato, Eva Aparecida e Maria Claudia de Oliveira Lopes.

Agradeço à Secretaria de Estado de Educação do Distrito Federal, que me concedeu um período de afastamento remunerado para estudos, determinante para a conclusão desta dissertação.

Agradeço às professoras Gabriela Mieto, Fátima Vidal e Eva Aparecida, que aceitaram participar da banca examinadora desta dissertação.

Agradeço aos funcionários da secretaria da Pós-Graduação, principalmente à Cláudia e às estagiárias, pela presteza e pela gentileza no atendimento das demandas.

Agradeço aos colegas de mestrado que também colaboraram com os meus estudos, como minhas queridas amigas Nilcea Moreno, Angélica Silva e Cátia Candido. 
Agradeço aos colegas do grupo Diálogo em Psicologia por terem me ajudado em momentos de dúvidas, de escrita e de pesquisa, especialmente, Fabiana Mendonça, Carine Silva, Raquel Capucci, Angélica Silva, Eva Aparecida, Marina Costa, Patrícia Osandón, Bruna Pacheco, Candida Souza, Fabrício Abreu, Rosa Monteiro, Daniele Souza, Alexandre Mourão e Andressa Moreira.

Agradeço a todos os profissionais de educação que contribuíram para minha pesquisa.

Agradeço a todos os colegas, amigos e professores, que direta ou indiretamente me ajudaram nesse trabalho. 
"Todos os dias quando acordo.

Não tenho mais o tempo que passou.

Mas tenho muito tempo.

Temos todo o tempo do mundo.

Todos os dias antes de dormir.

Lembro e esqueço como foi o dia.

Sempre em frente.

Não temos tempo a perder.

Nosso suor sagrado.

É bem mais belo que esse sangue amargo.

E tão sério.

E selvagem.

Selvagem.

Selvagem.

Veja o sol dessa manhã tão cinza.

A tempestade que chega é da cor dos teus olhos.

Castanhos.

Então me abraça forte.

E diz mais uma vez.

Que já estamos distantes de tudo.

Temos nosso próprio tempo. 
Não tenho medo do escuro. Mas deixe as luzes acesas, agora. O que foi escondido, é o que se escondeu. E o que foi prometido, ninguém prometeu.

Nem foi tempo perdido.

Somos tão jovens.

Tão jovens.

Tão jovens. "

Tempos Perdidos

(Renato Russo - Legião Urbana) 


\section{Resumo}

A presente dissertação tem como principal objetivo analisar as narrativas de seis professores da rede pública de ensino do Distrito Federal sobre o processo de inclusão dos alunos com deficiência intelectual (implementado nos últimos vinte anos, aproximadamente) e os desafios pedagógicos dele decorrentes. Para tanto, a pesquisa teve como base teórica a perspectiva histórico-cultural empreendida por Lev S. Vigotski (1896-1934) e seus colaboradores. A metodologia utilizada foi a pesquisa qualitativa, por meio da realização de entrevistas semiestruturadas. O trabalho de construção de dados envolveu gravação de áudio e transcrição integral das entrevistas, analisadas sob os pontos que se destacaram ao longo da análise dos dados de pesquisa. No primeiro eixo, observamos a resistência e o medo do professor com relação à implementação da política pública de inclusão, assim como o debate inicial sobre a inclusão escolar, a transformação do ambiente escolar e a disparidade temporal da implementação das políticas públicas de inclusão. No segundo eixo, foram analisados o impacto do processo inclusivo nas estratégias pedagógicas do professor no ensino do aluno com deficiência intelectual e os aspectos positivos e negativos que a inclusão trouxe para o desenvolvimento do processo de ensino-aprendizagem do aluno com deficiência intelectual. Concluímos, a partir da construção dos dados, que, desde o início da implementação das políticas públicas inclusivas, o debate teórico sobre a temática ocorreu de forma desconectada da realidade dos educadores e dos educandos, levando à resistência e ao medo dos docentes, uma desigualdade dos processos formativos docentes sobre as políticas de inclusão que foram implementadas, assim como uma clara disparidade temporal entre a efetivação das políticas públicas de inclusão escolar, aplicadas pelo governo distrital. Discutiu-se também que as educadoras se utilizam de várias estratégias pedagógicas como o concretismo e a ludicidade no ensino dos alunos com deficiência intelectual e, quanto aos aspectos positivos e negativos, as educadoras salientam que há a necessidade de transformações de base que promovam e desenvolvam a inclusão em aspectos estruturais do ambiente escolar e de formação docente.

Palavras-chave: Inclusão escolar; deficiência intelectual; perspectiva histórico-cultural; formação docente. 


\begin{abstract}
The main objective of this dissertation is to analyze the narratives of six teachers of the public school system of the Federal District about the process of inclusion of students with intellectual disabilities (implemented in the last twenty years or so) and the pedagogical challenges arising therefrom. For that, the research was based on the historical-cultural perspective undertaken by Lev S. Vigotski (1896-1934) and his collaborators. The methodology used was qualitative research, through semi-structured interviews. The data construction work involved audio recording and full transcription of the interviews, analyzed under the points that stood out during the analysis of the research data. In the first axis, we observe the teacher's resistance and fear regarding the implementation of the public policy of inclusion, as well as the initial debate on school inclusion, the transformation of the school environment and the time gap between the implementation of public inclusion policies. In the second axis, the impact of the inclusive process on the pedagogical strategies of the teacher in the teaching of the student with intellectual disability was analyzed, as well the positive and negative aspects that the inclusion brought to the development of the teaching-learning process of the student with intellectual disability. We conclude from the construction of the data that, since the beginning of the implementation of inclusive public policies, the theoretical debate on the theme occurred disconnected from the reality of educators and students, leading to resistance and fear of teachers, an inequality of Educational training processes on the inclusion policies that were implemented, as well as a temporal disparity between the implementation of the public policies of school inclusion applied by the district government. We also discuss the fact that educators use various pedagogical strategies such as concretism and playfulness in the teaching of students with intellectual disabilities, and, on the positive and negative aspects, educators emphasize that there is a need for basic transformations to promote and develop inclusion in structural aspects of the school environment and teacher training.
\end{abstract}

Key-words: School inclusion; intellectual disability; Historical-cultural perspective; teacher training. 


\section{Sumário}

Apresentação

Capítulo 1 - A trajetória histórica da educação das pessoas com deficiência Intelectuais rumo à inclusão

1.1. Panorama geral - A História da Deficiência Intelectual

1.2. Panorama Brasileiro - A pessoa com deficiência intelectual no Brasil 16

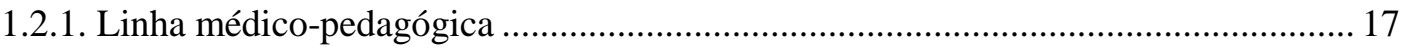

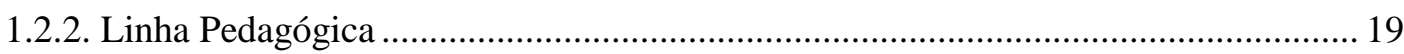

1.2.3. Processos educacionais e paradigmas sobre deficiência intelectual.......................... 21

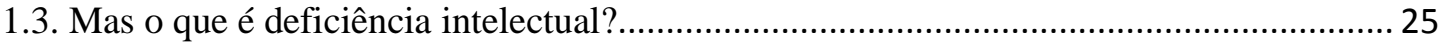

Capítulo 2 - Os modelos pedagógicos e as políticas públicas de inclusão para o atendimento à pessoa com deficiência no Brasil

2.1. As ideias contemporâneas de Vigotski no campo da educação inclusiva da pessoa com deficiência intelectual.

2.2. Educação e sala de aula: os desafios da inclusão do aluno com deficiência intelectual .. 40

2.3. Delimitação do problema: os desafios das políticas educacionais e a formação docente 40

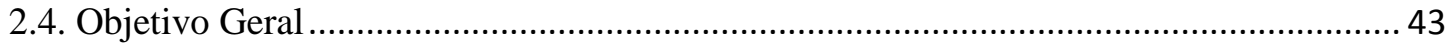

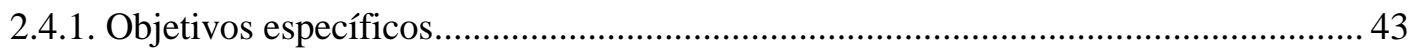

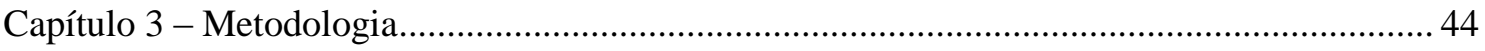

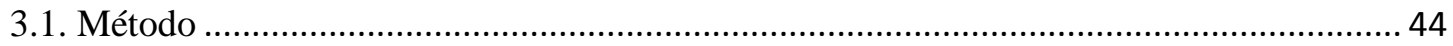

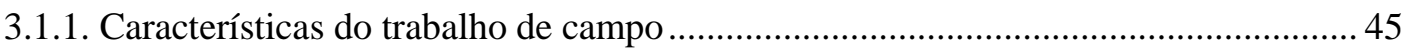

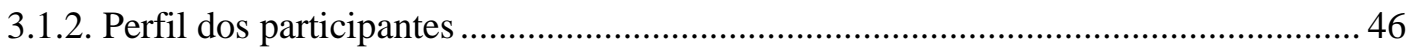

Capítulo 4 - Análise e discussão dos dados ................................................................................ 50

4.1. Eixo A: As políticas de inclusão implementadas pela SEEDF e o impacto das mesmas na escola

4.2.Eixo B: $\mathrm{O}$ aluno com deficiência intelectual e as estratégias pedagógicas utilizadas pelos professores na educação inclusiva ao longo das últimas duas décadas ......................................66

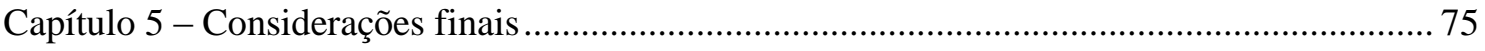

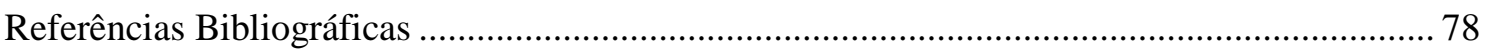

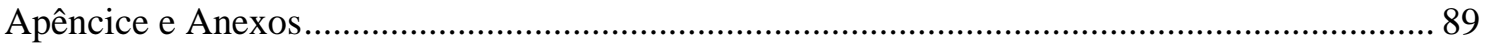


Apêndice A: Roteiro das entrevistas semiestruturada.....

Anexo A: Termo de consentimento livre e esclarecido .............................................................. 91

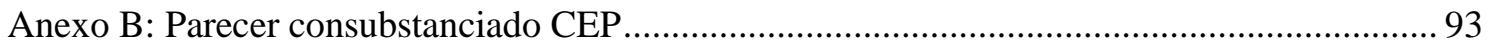




\title{
Apresentação
}

\author{
"O caminho da perfeição passa pela \\ superação dos impedimentos, a dificuldade \\ da função constitui o estímulo para sua \\ elevação" (Vigotski, 1934-2012, p. 43, \\ tradução nossa).
}

Recentemente, presenciou-se no panorama nacional a emergência de políticas públicas voltadas para a inclusão em escolas regulares dos alunos consideradas pessoas com deficiência. Esse movimento político decorreu de mudanças e transformações sociais profundas e parte da constatação de que estas pessoas são seres humanos capazes de aprender e se desenvolver (Coelho, 2010; Góes \& Laplane, 2013; Veltrone \& Mendes, 2007). Contudo, observa-se um abismo entre as políticas públicas de inclusão e o que de fato tem acontecido no cotidiano da sala de aula.

Atuei em vários âmbitos do ensino de alunos com deficiência na Secretaria de Estado de Educação do Distrito Federal, na Regional de Ensino de Ceilândia, no qual trabalhei como Coordenadora intermediária de ensino especial no Núcleo de Planejamento e Controle, matriculando os alunos com necessidades educacionais especiais nas escolas de Ceilândia, conforme suas especificidades e seu tipo de atendimento, atendendo às legislações vigentes sobre o Ensino Especial e Inclusão, em conformidade com a estratégia de matrícula da Secretaria de Estado de Educação do Distrito Federal. Esse trabalho me qualificou para atuar no Núcleo de Coordenação Pedagógica, como Coordenadora do Ensino Especial, que me fez verificar as dificuldades que os professores que atuam no ensino inclusivo têm em fazer adequação curricular para os alunos incluídos e também a dificuldade em ensinar tais sujeitos.

Todo esse panorama me permitiu identificar fases da implementação das políticas e, ao mesmo tempo, presenciar várias modalidades de inclusão: muitas distanciadas dos preceitos colocados nas diversas regulamentações. Surgiu então um interesse em estudar mais profundamente o processo de inclusão de alunos com deficiência intelectual na rede pública de ensino do Distrito Federal, articulado com a legislação que deveria ser respeitada. Por isso, realizei um trabalho investigativo sobre as narrativas docentes acerca das políticas de inclusão implementadas nos últimos vinte anos, aproximadamente, no Distrito Federal e os desafios delas decorrentes.

Nessa linha, a presente pesquisa entrevistou professores com mais de vinte anos de atuação no ensino público que trabalharam com a inclusão de alunos com deficiência 
intelectual. Pretendeu-se identificar, em forma de narrativas, o modo como estes profissionais narram a implementação e o desenvolvimento das políticas voltadas para inclusão e os desafios que foram enfrentados no cotidiano da sala de aula. Para tanto, por meio das narrativas, analisei as etapas de inserção escolar e a legislação relacionada ao processo de inclusão; sua efetiva aplicação nas instâncias pedagógicas.

Tanto as leituras teóricas quanto as análises a seguir baseiam-se no legado empreendido por Lev S. Vigotski (1896-1934), um dos precursores da perspectiva histórico-cultural, que procura compreender o psiquismo humano a partir da ação do homem sobre o mundo.

Para tanto, no primeiro capítulo, realizei um apanhado histórico da deficiência intelectual no mundo ocidental, iniciando pelo panorama mundial da trajetória da deficiência, depois passando ao contexto brasileiro da visão da deficiência intelectual, situando este trabalho na realidade nacional. O capítulo foi concluído com uma discussão sobre os conceitos de deficiência, normalidade, doença e saúde, essencial para o debate educacional e as diferentes perspectivas oriundas dele.

No capítulo seguinte, a análise volta-se para os modelos pedagógicos do ensino inclusivo para a educação da pessoa com deficiência intelectual, por meio da perspectiva histórico-cultural. O foco está nas políticas públicas de inclusão, perpassando pelas teorias de Lev Vigotski, com ênfase na defectologia, além dos desafios do ensino do aluno com deficiência intelectual, culminando nos trabalhos pedagógicos derivados dessa política pública de inclusão que impactam a formação docente.

No terceiro capítulo, descrevi a metodologia adotada - pesquisa qualitativa - e o instrumento utilizado para desenvolvimento do método - a entrevista semiestruturada com educadores da rede pública de ensino do Distrito Federal que tiveram contato com a política de inclusão nos últimos vinte anos, aproximadamente.

No quarto capítulo, voltado para a apresentação dos resultados, a análise se estruturou em dois eixos: A e B. A) a partir das narrativas dos docentes, foram avaliadas as políticas de inclusão fomentadas pela Secretaria de Estado de Educação do Distrito Federal, por meio da percepção do impacto dessa mudança na implementação das políticas educacionais inclusivas, tanto no cotidiano escolar quanto na formação docente; B) foram analisadas as estratégias pedagógicas adotadas pelos docentes a partir de suas experiências no ensino do aluno com deficiência intelectual, durante as últimas duas décadas, além da avaliação docente dos resultados, positivos ou negativos, da implementação e do desenvolvimento do processo inclusivo nas escolas de rede pública do Distrito Federal. 
No quinto e último capítulo, elaborei as considerações finais resultantes do percurso analítico empreendido neste processo investigativo, de modo a contribuir para a discussão sobre as políticas públicas inclusivas no Distrito Federal, além de procurar refletir sobre a necessidade de uma formação docente mais direcionada ao público com deficiências e suas especificidades educacionais e sociais. 


\section{Capítulo 1 - A trajetória histórica da educação das pessoas com deficiência intelectual rumo à inclusão}

"Não devemos nos conformar mais com o fato de que a escola especial se aplique simplesmente a um programa reduzido da escola comum, nem com seus métodos facilitados e simplificados. À escola especial se encontra a tarefa de criação positiva, de gerar formas de trabalho próprias que respondam para as peculiaridades de seus educandos" (Vigotski, 1934-2012, p. 33, tradução nossa).

Os aspectos históricos relacionados à conceituação da deficiência intelectual passaram por várias interposições de ideias e concepções de estudiosos que se interessavam pelo assunto (Jannuzzi,1985; Padilha, 2004; Padilha, 2007; Pessotti, 1984; Tunes \& Bartholo, 2010). Conforme os preceitos e valores predominantes em cada momento histórico, buscou-se compreender os sujeitas pessoas com deficiência intelectuais a partir de referenciais religiosos e/ou biomédicos, o que levou ao desenvolvimento de crenças e atitudes socioculturais excludentes para com eles ao longo da história (Coelho, 2010). Sem dúvida, ainda hoje, as políticas de inclusão educacional para as pessoas com deficiência intelectuais se defrontam com o tratamento dessas pessoas no passado, quando ocorriam práticas de abandono, confinamento e eliminação.

É complicada a conceituação de deficiência mental ${ }^{1}$ em épocas anteriores à Idade Média por existirem poucas bases documentais (Pessotti, 1984). Porém encontram-se estudos que revelam exemplos e conjecturas sobre o histórico dessa deficiência (Bianchetti, 1998; Carmo, 1991; Jannuzzi, 1985; Pessotti, 1984; Silva, 1986; Souza, 2007). Tunes, Souza e Rangel (1996), de acordo com a classificação de Pessotti (1984), identificam três estágios evolutivos para conceituar e entender a deficiência mental, a saber: o primeiro estágio é o teológico - que se caracteriza pela ideia de Deus, principalmente no Cristianismo na Europa, como explicação para tal deficiência, sendo, portanto, dever da religião tratar deste assunto. O segundo estágio se dá pela visão organicista e especulação médica - nas quais a pessoa com deficiência é "declarado" (p. 9) inocente por sua deficiência e o ensino passa a se responsabilizar por estes sujeitos. Por

\footnotetext{
${ }^{1}$ Há, no texto, a tensão entre os termos deficiência mental e deficiência intelectual que é proposital. Assim, referimo-nos à primeira nomenclatura para tratar de questões históricas, enquanto que a segunda refere-se à denominação atual, que atende aos preceitos da AAIDD (American Association on Intelectual and Developmental Disabilities) $\left(11^{\mathrm{a}}, 2010\right)$.
} 
último, o terceiro estágio é o científico, o qual se caracteriza pelos avanços nos estudos sobre deficiências no campo das ciências naturais e filosofia humanística, e também pelo surgimento da educação inclusiva para estas pessoas.

Veremos, portanto, neste capítulo, os aspectos históricos relacionados à conceituação das pessoas com deficiência intelectuais de modo geral e no Brasil. Para se entender como a sociedade trata a pessoa com deficiência, há a necessidade de se reportar ao passado, para identificar o retrato cultural que se fixou nas ideias acerca das diferenças e as transformações ocorridas ao longo do tempo, para que hoje se encontre um modelo de atendimento aas pessoas com deficiência, principalmente no ensino regular (Platt, 1999).

\subsection{Panorama geral - A História da Deficiência Intelectual}

Os estudos de Souza (2007) relatam que, na antiguidade, nas sociedades tribais, a sobrevivência do homem estava no que a natureza lhe proporcionava, submetido às condições de vários deslocamentos territoriais. Com isso, o homem deveria colaborar com o grupo do qual fazia parte, sendo que, nestas condições, os mais fortes prevaleciam. Desta forma, caso um membro do grupo apresentasse algum tipo de deficiência, este era abandonado pelo grupo. Atitudes como esta, muitas vezes, estavam relacionadas às crenças e aos ritos religiosos.

Para os antigos hebreus (1445-1404 a.C.), a deficiência era indicação de impureza e pecado. Moisés cita, no livro de Levítico (Bíblia, 2009, Levítico, Cap. 21, vers. 18-20), as regras que desqualificam as pessoas com deficiência para a religião, pois acreditava-se que nenhum homem que tivesse uma deformidade poderia ofertar ao Senhor (Silva, 1986).

Souza (2007), citando Platão (428-348 a.C.), indica que, enquanto ele conjecturava sobre uma república para a Grécia, dizia que as crianças da elite deveriam ser entregues aos lares comuns, já as deformadas deveriam ser levadas aos paradeiros desconhecidos e secretos. Num diálogo entre Glauco e Sócrates, pode-se depreender:

Sócrates - As crianças, à medida que forem nascendo, serão entregues a pessoas encarregadas de cuidar delas, homens, mulheres ou homens e mulheres juntos, pois as responsabilidades são comuns aos dois sexos.

Glauco - Estou de acordo.

Sócrates - Estes encarregados levarão os filhos dos indivíduos de elite a um lar comum, onde serão confiados a amas que residem à parte, num bairro da cidade. Para os 
filhos dos indivíduos inferiores e mesmo os dos outros que tenham alguma deformidade, serão levados a paradeiro desconhecido e secreto.

Glauco - É um meio seguro de preservar a pureza da raça dos guerreiros (Platão, 1997, p. 214).

Aristóteles (384-322 a.C.), por sua vez, acreditava que deveria existir leis que proibissem a criação e procriação de crianças disformes.

$\mathrm{Na}$ Grécia antiga, a economia se dava por atividades de produção, comércio agrícola e artesanato, porém o poder sociopolítico estava nas mãos de uma minoria que excluía as demais categorias da sociedade; assim, as pessoas com deficiência eram exterminadas por abandono sem representar um problema ético. Para os espartanos, as crianças com deficiências físicas e/ou mentais eram consideradas sub-humanas. Dessa forma, tais crianças eram abandonadas ou eliminadas, o que corroborava os ideais da época, que eram formar crianças atléticas para práticas de guerra (Souza, 2007).

Com o surgimento do cristianismo, na Europa, a Igreja Católica se fortalece, o que causou uma mudança no cenário político-administrativo da sociedade. O Clero assume o poder, vedando o direito daqueles que acreditavam ser pecadores a subirem aos Céus. Nesta sociedade, feudal, as pessoas com deficiência intelectual passaram, então, de coisa a pessoa. Ou seja, não poderiam ser mais exterminadas, por serem criaturas de Deus, mas eram abandonadas à própria sorte. Portanto, na Idade Média, a pessoa com deficiência intelectual era concebida como criatura de Deus, mas, apesar de cristão, era um pecador que, apesar de culpado por sua condição, ganha abrigo e alimentação em conventos e asilos. Contanto, por ser pecador é merecedor de castigo divino (Pessotti, 1984).

Admitia-se neste contexto que muitas pessoas com deficiência eram frutos de possessões demoníacas, de bruxarias de origem maligna. Por isso, comumente eram submetidos a flagelações, exorcismos ou eram jogados em fogueiras da Inquisição (Lopes, 2005). Nisto, indica Pessotti (1984) que "dada a credulidade da população rural e seu fanatismo clerical, não surpreende que, entre as cem mil pessoas queimadas por bruxaria, ... estivessem incluídos centenas de dementes e amentes ou deficientes mentais" (p. 9).

De acordo com Pessotti (1984), depois da Inquisição, as pessoas passaram a ver a deficiência como um problema médico, passível de tratamento, de modo que o fatalismo teológico dá lugar à fatalidade hereditária. Dessa forma, a primeira lei que distingue doente mental de deficiente mental data do século XIV, quando Eduardo II, rei da Inglaterra, baixa a "Prerrogativa Regis", de 1325, segundo a qual os bens da pessoa com deficiência passariam a ser zelados pelo rei. 
Contudo, durante a Reforma, as pessoas com deficiência mental, ainda eram considerados seres diabólicos. Existia uma rigidez ética em Calvino e Lutero, pois acreditavam na cólera e no castigo de Deus como uma predestinação e viam os idiotas, imbecis e loucos como marca da intolerância, explicada pela visão pessimista do homem. Para Lutero, existia uma ambiguidade curiosa, pois, ao mesmo tempo em que se matava tais pessoas para expulsar o demônio, ele orava por elas. Para ele, ambas eram práticas igualmente eficazes e morais (Pessotti, 1984).

Ainda no século XVI, a transição do feudalismo para o capitalismo repercute em grandes mudanças na sociedade, alterando, inclusive, as concepções sobre deficiência. Começaram a surgir ideias referentes à natureza orgânica das pessoas com deficiência mental, que passam a ser tratados por alquimia, magia, astrologia e medicina. Paracelso (1493-1541) e Cardano (1501-1576) acreditavam que sujeitos com peculiaridades apresentavam bizarrices em decorrência de forças cósmicas, resultando em traumatismos e doenças. Thomas Willis (16211675), médico, anatomista e fisiologista, fez uma interpretação organicista da deficiência mental, acreditando ser uma lesão ou disfunção do sistema nervoso central (Pessotti, 1984; Souza, 2007).

Neste contexto, Pessotti (1984) ressalta a contribuição de alguns autores que desenvolveram teorias importantes. Dentre eles, Condillac (1715-1780), em 1746 e 1749, transformou a teoria do conhecimento em teoria da aprendizagem, propondo uma didática especial para o as pessoas com deficiência intelectual. Em 1791, foi escrito o Tratado do Bócio e do Cretinismo, por J. Emanuel Fodéré (1764-1835), cuja tese dirigirá o pensamento médico até o século XX, que formula a lei em que o bócio é o primeiro degrau da degenerescência, acabando no cretinismo, que seria a forma mais grave da deficiência mental.

Philippe Pinel (1745-1826), em 1801, considerou a deficiência mental como orgânica e neuropatológica, no seu tratado médico-filosófico sobre alienação mental. Jean Marc Gaspard Itard (1774-1838), médico, reeducador, foi convidado, em 1801, pelo Ministro da França para educar o menino selvagem de Aveyron ${ }^{2}$, para o qual propõe a desmunização, adotando a leitura

\footnotetext{
${ }^{2} \mathrm{O}$ menino selvagem de Aveyron, que Itard chamou de Victór, que interessava-se pelo som "o", foi capturado em 1797 na floresta de La Coune. Em 1800, deixa-se prender em um jardim, é internado em um asilo e examinado pelo naturalista Bonnaterre. Ele registra minuciosas observações acerca de sua estrutura e comportamento. Quando o Ministro do Interior da França, Champagny, ordena que ele seja enviado a Paris e confiado a Itard, que o submete ao exame do psiquiatra francês Phillippe Pinel. O médico Pinel diagnostica Victór como um indivíduo que não é desprovido de recursos intelectuais, mas um idiota essencial. Itard se opõe ao diagnóstico por acreditar que o homem não nasce como homem, mas é construído como homem, percebia a idiotia do selvagem, mas não o entendia como um defeito biológico e, sim, como fato de insuficiência cultural: ele era o bom selvagem, a estátua e a tábula rasa (Pessotti, 1984).
} 
labial e expressão oral. Ao escrever a Mémoire (1787), lança fundamentos da teoria da avaliação e da didática na área da deficiência mental.

Esquirol (1772-1840), em 1818, foi o que mais influenciou o pensamento médico sobre a deficiência, estabelecendo a identidade da idiotia, distinta da loucura, e definindo-a como ausência de desenvolvimento intelectual. A partir de suas contribuições, a idiotia deixa de ser uma doença e passou a ter um critério de análise no rendimento educacional. Guggenbuhl (1816-1863), em 1840, funda uma colônia para cretinos e idiotas chamada escola de Àbendberg, empreendendo uma proposta de educação para tais pessoas, na qual a ideia de incurabilidade não repele a de educabilidade. Esta é entendida como possibilidade de ajustes socioculturais de portadores de disfunção ou lesão orgânica incurável, hereditária ou não, estimulando discussões sobre a metodologia de ensino para o as pessoas com deficiência intelectual (Pessotti, 1984).

Continuando o apanhado histórico da deficiência mental, Pessotti (1984) explicita que, em 1808, Augusto Frederico Froebel (1782-1852) sugeriu um sistema de educação especial para a primeira infância, aplicável também as pessoas com deficiência mental, no qual utilizava materiais especiais, simples e eficazes, aliados a atividades físicas, como recursos didáticos. Já Édouard Séguin (1812-1880), a partir de estudos em 1846, é o primeiro especialista em deficiência mental e no ensino de tais sujeitos na nossa história, que conciliou a ideia da incurabilidade e inevitabilidade (dos organicistas) com a de educabilidade (partilhada por pedagogos e alguns médicos).

A conceituação da deficiência intelectual defronta-se até hoje com preconceitos que têm origem na hegemonia doutrinária da medicina, durante os séculos XVIII e XIX. Esta teoria começa a ser abalada no século XX, graças aos progressos da psicologia, biologia, genética e as iniciativas pedagógicas ousadas, que a desafiaram e revolucionaram (Pessotti, 1984).

Historicamente, percebe-se que houve uma mudança gradativa sobre o olhar voltado para a pessoa com deficiência intelectual. Estes movimentos foram lentos e hesitantes, porém tem havido progresso nos resultados. Compreende-se que as práticas segregacionistas foram prejudiciais tanto a pessoa com deficiência quanto à sociedade, pois repercutiu em estigmas sociais e de rejeição (Karagiannis, Stainback \& Stainback, 1999).

Tendo em vista a necessidade de uma contextualização para o entendimento da situação da deficiência no tempo e no espaço, derivado do enfoque social no qual ela se localiza, passamos, no tópico seguinte, à análise da situação histórica da deficiência, no Brasil.

\subsection{Panorama Brasileiro - A pessoa com deficiência intelectual no Brasil}


De acordo com Jannuzzi (1985), no contexto brasileiro, na época do império, a educação de pessoas com deficiência mental foi deixada de lado, diante de uma sociedade predominantemente rural e não escolarizada, pois não se mostrava ou falava sobre tais pessoas. Mas, com o avanço da escolarização, foram sendo organizadas escolas para estes sujeitos.

Contudo, como a educação no Brasil somente foi institucionalizada entre o final do século XVIII e começo do século XIX, a Educação Especial teve início apenas em 1854, marcada por iniciativas particulares. Desse modo, as primeiras instituições para pessoas com deficiência mental surgiram no final do império, em Salvador (1874), com o Hospital Juliano Moreira e, no Rio de Janeiro (1887), com a Escola México. A criação destes institutos caracterizou-se como conquista para as possibilidades educacionais. Estas instituições eram administradas pelo Estado e surgiram para atender casos graves de deficiência mental, os quais se acreditava serem problemas médicos (Buccio, 2007; Jannuzzi, 1985; Teles, 2010).

De fato, o crescimento da preocupação em relação à educação das pessoas com deficiência acompanhava as transformações sociais do país. Surgiam instituições de ensino para tais sujeitos por meio do empenho de algumas pessoas que se sensibilizavam com o problema e também que encontravam apoio do governo.

Com a proclamação da República (1889) e a adoção da Constituição de 1891, admitiuse que cada estado tivesse uma independência governamental. Com isso, o Congresso permitiu a criação de instituições de ensino superior e secundário, porém descartou a obrigação e gratuidade da educação primária. Depois da $1^{\text {a }}$ Guerra Mundial (1918), o governo federal interferiu economicamente na educação primária, fazendo com que os estados de São Paulo, Rio Grande do Sul e Rio de Janeiro organizassem escolas primárias e escolas para pessoas com deficiência mental. Profissionais como médicos, psicólogos e professores foram se organizando e refletindo as práticas pedagógicas e tornando possível a vida dos mais prejudicados. Salientase, portanto, que o modelo médico e clínico fundamentou as bases educacionais desde o começo do século XX, norteando o atendimento a essas pessoas até hoje (Jannuzzi, 1985).

\subsubsection{Linha médico-pedagógica}

De acordo com o apanhado histórico feito por Jannuzzi (1985), os médicos preocupados com a educação das pessoas com deficiência mental criaram instituições escolares junto aos hospitais psiquiátricos. Com a criação do Pavilhão Bourneville, no Rio de Janeiro, que era anexo ao Hospício Praia Vermelha, foi criada uma comissão presidida por três médicos e um farmacêutico para o tratamento e a educação dessas crianças. Eles acreditavam que elas poderiam melhorar tendo tratamento clínico e educacional. 
Estas instituições anexas aos hospitais psiquiátricos tornaram-se possíveis devido à preocupação médico-pedagógica, no entanto tinham um intuito de segregação social. Contudo foi um passo dado na tentativa de não limitar essas crianças só aos serviços médicos inserindoas no campo educacional, "estabelecendo-se na educação do 'deficiente': segregação versus integração na prática social mais ampla" (Jannuzzi, 1985, p. 35).

Os estudos científicos, no Brasil, baseavam-se nos discursos médicos. Estes profissionais escreveram trabalhos, firmados em suas pesquisas, que colaboraram de forma significativa para a educação dos sujeitos com deficiência intelectual. Nesse ínterim, podemos citar os estudos de Carlos Fernandes Eiras, em 1900, que apresentou a monografia Da Educação e Tratamento Médico-Pedagógico dos Idiotas; Clemente Quaglio (1872-1948), que escreveu, em 1913,A educação da infância anormal da inteligência no Brasil; Basílio de Magalhães (1874-1957), em 1917, que publicou o Tratamento e educação das crianças anormais da inteligência e A educação da infância anormal e das crianças mentalmente atrasadas na América Latina;Alfredo Oliveira Vieira,que publicou o livro Testamens para a educação dos anormais, em 1917, na Bahia; Vieira de Mello, em 1917, que publicou a obra Débeis mentais na escola pública e Higiene Escolar e Pedagogia, na qual apresentou normas para a inspeção em escolas. Entre suas atribuições estavam a seleção dos anormais e qual regime especial eles necessitavam, além da criação de classes, escolas e formação profissional para estas pessoas. Em Pernambuco, o médico higienista Ulysses Pernambucano, em 1918, publicou o trabalho Classificação de crianças anormais, considerada como a primeira tese brasileira no campo da deficiência mental (Souza, 2007).

Januzzi (2004) revela que as crianças com deficiência mental eram avaliadas com o grau de inteligência em relação às crianças da mesma idade e também em relação a atenção e memória. Supondo-se que estivesse relacionada com o rendimento escolar do aluno, os estudiosos se preocupavam com uma "catalogação da anormalidade" (p. 37). Sendo assim, os médicos escolares deveriam classificar os alunos como anormais intelectuais, morais e pedagógicos.

Em 1929, organizou-se a primeira equipe para trabalhar com as crianças consideradas anormais, composta por psiquiatras, pedagogos e psicólogos. Anexa ao hospital psiquiátrico, a Escola Pacheco e Silva, nas dependências do hospital Juqueri (1929), abrigava crianças com debilidade mental, a saber: os imbecis e os idiotas. Esta escola era destinada ao tratamento médico-pedagógico, no qual o médico era o profissional principal e o pedagogo, seu auxiliar. $\mathrm{O}$ programa pedagógico se baseava em educação sensorial, ginástica, trabalhos manuais e uma 
alfabetização tímida, que se pautava no conceito dos 3 ' $\mathrm{M}$ ' - mental, manual e moral (Jannuzzi, 2004).

Os médicos Pacheco e Silva (1898-1988), Cantídio de Moura Campos (1889-1972) e José C. Macedo Soares (1883-1968) foram convidados a integrar a Comissão de Higiene Mental e Educação dos Anormais, em São Paulo. Existia, nesses parâmetros, duas classes para débeis mentais na Escola Primária José de Andrade (1933), na qual a educadora sanitária, além de auxiliar o psiquiatra e a criança na escola, auxiliava também a família dessas crianças.

No Rio de Janeiro, em 1934, Anísio Teixeira iniciou a organização dos médicos em torno da higiene mental. Tal trabalho começou em 1909, com o Comitê Nacional de Higiene Mental, mas sua influência nas escolas ocorreu a partir de 1933 com a organização da Seção de Ortofrenia $^{4}$ e Higiene Mental no Instituto de Pesquisas Educacionais, instalando clínicas de higiene mental nas escolas experimentais, articuladas às tarefas pedagógicas (Jannuzzi, 1985).

\subsubsection{Linha Pedagógica}

Além de uma perspectiva médico-pedagógica, que foi dominante em certa época, houve estudiosos que se preocuparam particularmente como uma percepção do problema cujo foco não residisse no diagnóstico médico, mas na elaboração de propostas e tratamento no âmbito educacional que promovessem uma educação satisfatória e evolutiva dos sujeitos com deficiência, além de uma consequente sociabilização diante do quadro alarmante da exclusão.

Em São Paulo, o professor Clemente Quaglio organizou em 1913 um Laboratório de Psicologia Experimental, no qual realizou pesquisas em duas escolas públicas e aplicou a escala métrica de Binet e Simon (que será explicada no próximo capítulo). Essa pesquisa foi realizada com 149 crianças nas duas escolas pesquisadas e encontrou, segundo seus parâmetros, $13 \%$ de crianças consideradas anormais de inteligência. Ele sugeriu, então, a seleção empírico-escolar, a qual seria realizada por professores e diretores, utilizando-se de questionários e observações. Após feito isso, a criança deveria ser encaminhada ao médico e, depois, selecionada para escolas especiais e asilos-escolas.

A linha pedagógica preocupava-se com aqueles que eram considerados pessoas acometidas por transtornos anormais de escola e não com pessoas acometidas com transtornos patológicos ou de hospícios, como se falava na época. Neste contexto, Norberto de Souza Pinto, em 1928 elaborou o conceito de deficiência mental a partir de normas escolares, no qual seriam

\footnotetext{
${ }^{3}$ 3'M' foi um conceito utilizado na América do Norte pelo Psiquiatra Pacheco e Silva, em 1929 (Jannuzzi, 2004).

${ }^{4}$ Arte de corrigir as tendências morais ou intelectuais (do Grego Ortho + pheren). Recuperado em 11 agosto 2016, de http://www.lexico.pt/ortofrenia/.
} 
retardatários todos os que nela não se adaptassem, como cegos, surdos-mudos, defeituosos, degenerados e os retardados intelectualmente.

Jannuzzi (1985) descreve a classificação de Souza Pinto (1928) em três categorias:

Os retardados de inteligência (arrières), que seriam "todas as crianças que, embora saibam se comunicar com seres semelhantes, oralmente ou por escrito, mostram, contudo, um atraso de 2 a 3 anos no seu percurso de estudos, sem que este atraso seja motivado pela falta de assiduidade escolar. Tais educandos aproveitam uma parte assaz diminuta dos métodos e processos didáticos" (Souza Pinto, 1928:11). ... Os instáveis ou contumazes, crianças que "os nossos atuais educadores crismam, durante a vida escolar, de indisciplinados, porque espalham cotidianamente a tagarelice, a turbulência, não raras vezes a hipocrisia e a delação. Representam na órbita escolar muitas vezes o papel de Silvério Reis em miniatura" (Souza Pinto, 1928:11). ... Os mistos, mescla dos dois grupos anteriores. Os dois últimos grupos necessitam de classes especiais. (Souza Pinto, 1929, apud Jannuzzi, 2004, pp. 66-67)

Dessa forma, Souza Pinto oscilava muito sobre suas percepções em relação à anormalidade e impunha ao professor sua detecção, além de ser, também, contra os testes psicológicos de inteligência. Porém o autor persistiu com os critérios da norma escolar como parâmetro de enquadramento desses alunos. Além disso, afirmava que a finalidade de educar tais alunos era em função deles mesmos, pois a maioria era susceptível de receber educação para se autossustentar e conviver em sociedade. Logo, precisavam de conhecimentos mais adequados para prevenir os efeitos da anormalidade. Para ele, o estudo da psicologia e da pedagogia ajudaria a conhecer os anormais e normais, aproveitando tais pessoas para trabalhos simplórios, de modo a evitar a criminalização, sob a perspectiva de que a educação preveniria futuros atos delituosos de crianças anormais, assegurando a ordem e o progresso da sociedade (Jannuzzi, 1985).

Souza Pinto ainda achava que, para educar as crianças anormais, era necessário passálas da segregação em escolas separadas para a admissão de classes especiais nos mesmos estabelecimentos de ensino. Ele dizia que quem deveria educá-las seria o Estado e a iniciativa particular. Também, atestou a responsabilidade do professor na eficiência do ensino e da aprendizagem. Souza Pinto também, na sua Escola para Retardatários (1917), procurou facilitar a vida dessas crianças, tornando possível a aprendizagem de atos simples para o convívio social.

O pensamento de Souza Pinto, assim, já indica uma contribuição inicial para os estudos pedagógicos e psicológicos, ainda que eivados de preconceitos históricos, em direção a uma noção primária da inclusão escolar. Ao indicar a necessidade da educação dos alunos com 
deficiência e sua integração ao cotidiano escolar de alunos ditos normais, esse educador deu subsídios para o fim da segregação e fundou bases para modelos educacionais ainda hoje presentes no contexto educacional. Mesmo com a criação de uma escola específica para o atendimento de estudantes ditos anormais, sua iniciativa foi importante para trazer perspectivas e esperanças para o ensino pessoas com deficiência intelectual, desde a possibilidade de escolarização até premissas para o processo de inclusão.

Outro nome que se destacou no campo da educação de pessoas com deficiência intelectual foi Helena Antipoff (1892-1974), que aprofundou os modelos educacionais na execução do processo de inclusão, sob a ideia de que os ditos anormais deveriam seguir a mesma organização escolar para alunos comuns. Aplicou a integração de alunos com deficiência em turmas regulares, além de ressaltar a importância da medicina e da psicologia no processo escolar. A educadora foi também a criadora do Instituto Pestalozzi, em 1935, possibilitando o acesso dos considerados anormais à educação pública, com metodologia própria (Jannuzzi, 1985).

Em 1954, é criada a Associação de Pais e Amigos dos Excepcionais (APAE), no Rio de Janeiro, constituindo-se como apoio aos responsáveis pelas pessoas com deficiência. Em 1958, o Ministério da Educação cria uma assistência técnico-financeira às instituições especializadas em pessoas com deficiência, além do lançamento de campanhas para a educação de pessoas com deficiência.

A primeira Lei de Diretrizes e Bases da Educação Nacional (Lei no 4.024/1961) foi um marco nas ações estatais na área da educação especial, incluindo o termo educação de excepcionais. Por meio dela, recomendava-se que a educação para a pessoa com deficiência devia se dar, dentro das possibilidades, no sistema geral de educação, além de direcionar recursos públicos para instituições privadas voltadas para a educação dessas pessoas.

\subsubsection{Processos educacionais e paradigmas sobre deficiência intelectual}

É inevitável compreender que a transição para o que existe hoje em termos de inclusão deriva de uma revisão dos conceitos e discursos acerca da deficiência, dando "um novo entendimento do que venha a ser tal condição existencial e, por consequência, novas formas de tratar tal condição. O cenário do mundo atual denota um movimento em direção a um sentido de inclusão social" (Rozek, 2009, p. 169). Tais esforços indicam que, ainda que não totalmente compreendida ou integrada ao espaço educacional, a antiga política de segregação acabou sendo substituída por uma visão de integração e inclusão ao espaço escolar e mesmo à sociedade.

Na década de 70, foi promulgada a segunda Lei de Diretrizes e Bases da Educação Nacional, Lei ${ }^{\circ} 5.692$ de 1971, feita num contexto de ditadura militar, que alterou a estrutura 
de ensino, criando novos níveis: o $1^{\circ}$ grau e o $2^{\circ}$ grau com o ensino técnico obrigatório. Esta lei define a necessidade de tratamento especial para alunos que apresentassem deficiência, cuja normatização seria definida por comissão específica. É criado, em 1973, o Centro Nacional de Educação Especial (Cenesp) ${ }^{5}$, responsável pela definição e política de Educação Especial. Em 1977, com a criação do Ministério da Previdência e Assistência Social, instauraram-se diretrizes para o atendimento do excepcional, integrando a assistência médico-psicossocial e de educação especial, definindo e delimitando as pessoas com deficiência, dispondo sobre encaminhamento, supervisão, controle e diagnóstico com um cunho assistencialista (Jannuzzi, 1985).

Também na década de 1970, com a crescente discussão em torno da pessoa com deficiência, inicia-se o discurso de integração, com um entendimento que representava uma inserção parcial das pessoas com deficiência na sociedade, numa prática menos segregacionista e preconceituosa, de forma que as pessoas com deficiência e não deficiência deveriam interagir. Para Pletsch (2014), “a integração pregava a preparação prévia dos alunos com necessidades educacionais especiais para que demonstrassem ter condições de acompanhar a turma no ensino regular, mediante apoio especializado" (p. 6). Isso não se distanciava de um modelo pedagógico calcado na medicina, ao entender a questão da deficiência como um problema próprio do aluno.

Ao longo dos anos, como foi aqui explanado, a educação da pessoa com deficiência ocorreu em escolas e classes especiais, para que estes indivíduos fossem identificados e preparados para o convívio social. Incidia a ideia de um corpo improdutivo, remetendo-lhes a uma condição de inferioridade em relação às pessoas economicamente produtivas, em que o trabalho é visto como uma terapia ocupacional. Contudo, para que ocorresse a integração era preciso haver mudanças no âmbito social, político e cultural (Marques, 1997).

Portanto, depreende-se que a criação de políticas públicas e uma tentativa de revisão educacional para o tratamento da deficiência foram marcos dos anos 70 para a educação especial. A definição da clientela para o ensino especial, a possibilidade de um currículo específico para esse público e a criação de instituições públicas e privadas voltadas para educação das pessoas com deficiência foram ações significativas desta época para uma intenção de integrar estes educandos.

Na segunda metade da década de 80, em alguns países da Europa e nos EUA, houve um consenso entre pesquisadores por uma necessidade de mudanças no processo de integração

\footnotetext{
${ }^{5}$ Final da década de 70, implantam-se cursos de formação de professores na área da educação especial. Com o fim da ditadura, ocorrem várias iniciativas no panorama de educação especial. O Cenesp, em 1985, torna-se Secretaria de Educação Especial. Percebe-se, portanto, que, na década de 70, se institucionalizou a educação especial devido ao aumento de textos legislativos, associações, estabelecimentos e financiamentos do poder público (Mendes, 2010).
} 
educacional. Duas propostas surgiram, sendo que a primeira seria a melhoria e o aprofundamento do conceito de integração, sugerindo a substituição do termo "normalização" pela expressão valorização dos papéis sociais. A segunda proposta de mudança trazia a discussão de um novo conceito que seria a Inclusão Escolar, que representava outra opção de inserção escolar que questionava as políticas e organizações da educação especial. Os críticos da integração e defensores da inclusão afirmavam que a escola ocultava o fracasso dos alunos com deficiência, isolando-os em serviços educacionais especiais, mas segregados. Assim, no final dos anos 80 e início da década de 90, começam a tomar dimensões as discussões em torno de um novo paradigma de atendimento escolar, a inclusão escolar (Dechichi, 2011).

Dessa forma, os princípios da Integração constituíram-se em movimento que antecedeu e foi de grande importância para a progressiva implementação do paradigma da inclusão. A proposta de uma educação inclusiva, além de proporcionar uma mudança de perspectiva educacional, propõe o apoio a todos os envolvidos no contexto do processo de inclusão escolar, para que se tenha uma sociedade livre de preconceitos e limitações (Sassaki, 1997).

A década de 90 representou um avanço considerável para o processo de inclusão não só de pessoas com deficiência, mas de outros sujeitos que fugissem ao dito padrão imaginário de aluno "normal" (Glat \& Nogueira, 2003, p.135). A definição de políticas supranacionais, como as conferências a seguir, é demonstrativa de um esforço coletivo e generalizado para estabelecer uma reorganização no ensino de alunos com deficiência.

A Conferência Mundial sobre Educação para Todos (1990), realizada na Tailândia, assim como a Declaração de Salamanca (1994), realizada na Espanha, determinaram linhas de ação para a inclusão de pessoas com necessidades especiais. Essa declaração foi resultado do encontro de mais de trezentos representantes de governos e Organizações Internacionais que objetivavam a educação para todos, visando uma escola integradora e capacitada. Este encontro reafirmou a Declaração Universal dos Direitos Humanos (1948), culminando na Declaração de Igualdade de Oportunidades para Pessoas com Deficiência, garantindo a educação do sujeito com necessidades educacionais especiais.

Na década de 90, o discurso de inclusão inicia-se no Brasil (Mendonça \& Silva, 2015). Entende-se, portanto, a inclusão como um fenômeno sociocultural, no qual se objetivava implementar políticas e propostas que implicam em uma perspectiva de transformação social. Em tais políticas, reivindica-se uma sociedade justa e igualitária, em que seja garantida equidade de oportunidades para todos os que nela vivem (Coelho, 2010). Nesse contexto, a sociedade inclusiva passa a ser considerada fundamental para o desenvolvimento do estado democrático, pois ela configura-se como parte integrante desse processo (Mendes, 2010). 
No entanto, os entraves associados à inclusão ainda são muitos e variados, podendo ser evidenciados, por exemplo, no desrespeito à pessoa com deficiência por parte da população em geral. O preconceito e a discriminação, a falta de formação específica e adequada dos docentes, bem como a falta de acessibilidade, de estrutura e materiais didáticos apropriados são fatores que ainda impedem que tenhamos uma efetiva educação inclusiva que possibilite o aprendizado das pessoas com necessidades educacionais (Glat, Mascaro, Antunes, \& Marin, 2011; Veltrone $\&$ Mendes, 2007).

Para Mendonça e Silva (2015), contudo, são evidentes os ganhos educacionais e sociais alcançados pelas políticas e propostas de inclusão, pois estas representam um avanço nos modelos de atendimento até então propostos. Visando oferecer educação de qualidade para o atendimento de todos os alunos, independentemente de "suas condições físicas, culturais, sociais, econômicas, emocionais e culturais" (p. 39). No entanto, ainda existem muitos desafios e muitas barreiras a serem transpassadas.

Atualmente, no Brasil, as leis que regem a educação e, por conseguinte, a inclusão escolar são: a Constituição Federal (1988), a Lei de Diretrizes e Bases da Educação Nacional (Lei no 9.394/1996), o Estatuto da Criança e do Adolescente, o Plano Nacional de Educação, a Lei no 7.853/1989, a Lei Brasileira de Inclusão da Pessoa com Deficiência (Lei no 13.146/2015) e os Parâmetros Curriculares Nacionais, nos quais se estabelece que a educação é direito de todos, e que as pessoas com necessidades educacionais especiais terão atendimento educacional, preferencialmente, na rede regular de ensino, com direito a atendimento especializado. Esse compêndio legal, além de institucionalizar a educação inclusiva como um todo, indica formações específicas docentes para lidar com esse público e minimizar a exclusão não só escolar, mas também social, desses sujeitos.

Segundo Bezerra e Araújo (2011), "a inserção obrigatória de crianças com deficiência intelectual em escolas regulares só tomou proporções relevantes na primeira década do século XXI” (p. 278), reflexo da implantação e aplicação de leis específicas para a clientela de educação especial, além de uma progressiva ampliação de obrigações estatais em direção a esse público, desde a primeira infância até o processo de terminalidade.

Acerca da legislação do Distrito Federal, o processo de inclusão escolar é direcionado pela Resolução $n^{\circ}$ 01/2012 (alterada em seus dispositivos pela Resolução no 1/2014-CEDF, publicada no DODF $\mathrm{n}^{\circ}$ 43, de 26 de fevereiro de 2014), do Conselho de Educação do Distrito Federal, que define o que caracteriza os alunos com necessidades educacionais especiais no seu artigo 40. Nessa resolução, em seu artigo 42, definem-se, ainda, as possibilidades de atendimento da rede pública de ensino, no que se refere à educação especial. 
As legislações do Distrito Federal que regulamentou a educação inclusiva nas escolas públicas e/ou privadas são:

Lei Orgânica do Distrito Federal, de 08 de junho de 1993. - Lei n 2.352, de 26 de abril de 1999. Dispõe sobre o atendimento aos estudantes portadores de altas habilidades. • Decreto $\mathrm{n}^{\mathrm{o}}$ 22.912, de 25 de abril de 2002. Regulamenta a Lei $\mathrm{n}^{\mathrm{o}}$ 2.698/2001. Dispõe sobre atendimentos especializados aos estudantes portadores de deficiência na Educação Básica em estabelecimentos públicos e particulares do DF. - Lei $\mathrm{n}^{\circ} 3.218$, de 05 de novembro de 2003. Dispõe sobre a universalização da educação inclusiva nas escolas da rede pública de ensino do Distrito Federal. - Lei no 4.317, de 09 de abril de 2009. Institui a Política Distrital para Integração da Pessoa com Deficiência, consolida as normas de proteção e dá outras providências (Orientação Pedagógica, 2010, p. 21).

Desta forma a Secretaria de Estado de Educação do Distrito Federal instituiu estas leis para a implementação das políticas públicas de inclusão nas escolas públicas do Distrito Federal.

Nos últimos vinte anos, com leis que garantiram a educação para todos, tornou possível incluir os alunos com deficiências intelectuais em escolas regulares. Entretanto, as mediações pedagógicas nem sempre são eficientes: muitas vezes, a criança com deficiência intelectual está na sala de aula, mas segregada (Mendonça \& Silva, 2015). Por isso, atualmente cabe às escolas dispor de recursos e procedimentos não uniformes para que estes alunos caminhem além de seus limites.

\subsection{Mas o que é deficiência intelectual?}

Atualmente, o conceito de deficiência intelectual é baseado no sistema de classificação da AAIDD ${ }^{6}$, American Association on Intelectual and Developmental Disabilities (2011), que traz a denominação de deficiência intelectual (2010) em lugar de deficiência mental (19081958) ou retardo mental (1959-2009). A definição de deficiência intelectual, segundo a

\footnotetext{
${ }^{6}$ A AAIDD era denominada AAMR (American Association on Mental Retardation). Essa associação foi criada em 1876, na cidade de Washington, e define conceitos, classifica, apresenta modelos teóricos e orienta intervenções em diferentes áreas sobre a deficiência intelectual. Também influencia os sistemas de classificação, como o DSM (Manual Diagnóstico e Estatístico de Transtornos Mentais) e o CID (Classificação Internacional de Doenças). O modelo proposto pela AAMR direcionou para uma concepção multidimensional, funcional e bioecológica da deficiência intelectual, associada a inovações e reflexões teóricas e empíricas em relação aos modelos anteriores (Carvalho \& Maciel, 2003). Porém, a AAMR, reconhecido organismo internacional e o mais antigo do mundo no campo da deficiência intelectual, a partir de $1^{\circ}$ de janeiro de 2007, aceita uma nova nomenclatura, passando a designar-se American Association on Intelectual and Developmental Disabilities (AAIDD) (Souza, 2013).
} 
associação, é caracterizada por limitações significativas tanto em funcionamento intelectual ${ }^{7}$ como no comportamento adaptativo ${ }^{8}$, que abrange habilidades sociais e práticas cotidianas, devendo aparecer antes dos 18 anos.

As definições propostas pela AAIDD têm surtido um impacto nas mudanças de definições, concepções e práticas profissionais relacionadas com a deficiência intelectual em todo mundo. Sua influência sobre outros sistemas classificatórios é relevante. Esta associação rejeita uma concepção reducionista baseada somente em características patológicas da pessoa para propor uma concepção interacionista na qual o ambiente desempenha um papel substancial. A AAIDD abriu portas para um enfoque multidimencional, introduzindo a dimensão de participação, aprofundando-se no modelo de apoio que passou a ser considerável em relação ao modelo teórico, materializando e modificando aspectos essenciais do entendimento da classificação e dos critérios a se utilizar segundo sua finalidade. Historicamente, distinguem-se entre causas orgânicas e ambientais as condições nas quais se fazia referência como deficiência mental, retardo mental ou, mais recentemente, deficiência intelectual. Fatores pré-natais, perinatais e pós-natais distinguem conceitos das causas da deficiência (Alonso \& Schalock, 2010).

Souza (2013) acredita que não há uma análise uniforme para definir deficiência intelectual, pois esta se identifica por apresentar alterações psicológicas, sociais e emocionais, não correspondendo a uma doença, mas a um conjunto de síndromes que têm em comum a insuficiência intelectual. Para determinar se a pessoa tem deficiência intelectual, é necessário um diagnóstico realizado por uma equipe multidisciplinar. Esse diagnóstico tem a finalidade de identificar o tipo de atendimento que essas pessoas devem ter, assim como direcioná-las a usufruírem de direitos quanto aos benefícios e assistência previdenciária, proteção legal, acesso às cotas, entre outros. Dessa forma, o diagnóstico está ligado a práticas sociais. Para se realizar o diagnóstico é necessária a utilização de manuais de psiquiatria, dos sistemas internacionais de classificação, de entrevistas de anamnese e testes psicológicos, associados ao julgamento médico. O diagnóstico do aluno com deficiência intelectual é complexo e necessita de associações com fatores etiológicos como: biomédicos, comportamentais, sociais e educacionais (Carvalho \& Maciel, 2003).

Atualmente, esses diagnósticos são realizados com base na DSM-V (Manual Diagnóstico e Estatístico de Transtornos Mentais), na APA (American Psychiatric Association), no CID-10 (Classificação Internacional de Doenças), pela OMS (Organização Mundial de

\footnotetext{
${ }^{7}$ Funcionamento intelectual (também chamada inteligência) refere-se à capacidade mental geral, tais como a aprendizagem, raciocínio, resolução de problemas, e assim por diante (AAIDD, 2011).

${ }^{8}$ Comportamento adaptativo é o conjunto de habilidades conceituais, sociais e práticas que são aprendidas e executadas por pessoas em suas vidas cotidianas (AAIDD, 2011).
} 
Saúde), e pela CIF (Classificação Internacional de Funcionalidade e Saúde), organizada pela OMS (2001) e pela AAIDD (2010). A CIF é complementar à CID-10, a qual é utilizada no diagnóstico para conhecer a funcionalidade do sujeito, incluindo dimensões individuais e sociais. A CIF referencia dois modelos de deficiência intelectual, a biomédica e a social (Bridi \& Baptista, 2014). O Manual Diagnóstico e Estatístico de Transtornos Mentais (DSM), da American Psychiatric Association(APA), uma classificação de transtornos mentais e critérios associados, foi elaborado para facilitar o estabelecimento de diagnósticos mais confiáveis desses transtornos. Com sucessivas edições ao longo dos últimos anos, tornou-se uma referência para a prática clínica da área da saúde mental. Neste manual, a deficiência intelectual está dentro da classificação de Transtornos de Neurodesenvolvimento, que é definido como sendo um grupo de condições com início no período do desenvolvimento. Os transtornos tipicamente se manifestam cedo no desenvolvimento, em geral antes de a criança ingressar na escola, sendo caracterizados por déficits no desenvolvimento que acarretam prejuízos no funcionamento pessoal, social, acadêmico ou profissional. Os déficits de desenvolvimento variam desde limitações muito específicas na aprendizagem ou no controle de funções executivas até prejuízos globais em habilidades sociais ou inteligência. É frequente a ocorrência de mais de um transtorno do neurodesenvolvimento; ... A deficiência intelectual (transtorno do desenvolvimento intelectual) caracteriza-se por déficits em capacidades mentais genéricas, como raciocínio, solução de problemas, planejamento, pensamento abstrato, juízo, aprendizagem acadêmica e aprendizagem pela experiência. Os déficits resultam em prejuízos no funcionamento adaptativo, de modo que o indivíduo não consegue atingir padrões de independência pessoal e responsabilidade social em um ou mais aspectos da vida diária, incluindo comunicação, participação social, funcionamento acadêmico ou profissional e independência pessoal em casa ou na comunidade (American Psychiatric Association, 2014, p. 72).

A classificação dos transtornos está articulada com a Classificação Internacional de Doenças (CID), da Organização Mundial da Saúde (OMS), o sistema oficial de codificação. Os critérios da DSM definem transtornos identificados pela denominação diagnóstica e pela classificação alfanumérica da CID. No DSM-V, as codificações da CID-9-MC (Classificação Internacional de Doenças, 9a Revisão, Modificação Clínica) e da CID-10-MC (Classificação Internacional de Doenças, $10^{a}$ Revisão, Modificação Clínica) estão vinculadas aos transtornos relevantes na classificação e, agora, têm na DSM uma estrutura linear proposta pela CID-11 (APA, 2014). E, de acordo com o DSM-V, sobre o diagnóstico da Deficiência Intelectual, ou Transtorno do Desenvolvimento Intelectual, diz que: 
O uso de especificadores para diagnósticos de transtornos do neurodesenvolvimento enriquece a descrição do curso clínico e da sintomatologia atual do indivíduo. Além de especificadores descritores da apresentação clínica, como idade de início ou classificações da gravidade, os transtornos do neurodesenvolvimento podem incluir o especificador "associado a alguma condição médica ou genética conhecida ou a fator ambiental". Esse especificador oportuniza aos clínicos a documentação de fatores que podem ter desempenhado um papel na etiologia do transtorno, bem como daqueles capazes de afetar o curso clínico (APA, 2014, p.74).

E, de acordo com o CID-10, a deficiência intelectual é:

um transtorno com início no período do desenvolvimento que inclui déficits funcionais, tanto intelectuais quanto adaptativos, nos domínios conceitual, social e prático. Os três critérios a seguir devem ser preenchidos: A. Déficits em funções intelectuais como raciocínio, solução de problemas, planejamento, pensamento abstrato, juízo, aprendizagem acadêmica e aprendizagem pela experiência confirmados tanto pela avaliação clínica quanto por testes de inteligência padronizados e individualizados. B. Déficits em funções adaptativas que resultam em fracasso para atingir padrões de desenvolvimento e socioculturais em relação a independência pessoal e responsabilidade social. Sem apoio continuado, os déficits de adaptação limitam o funcionamento em uma ou mais atividades diárias, como comunicação, participação social e vida independente, e em múltiplos ambientes, como em casa, na escola, no local de trabalho e na comunidade. C. Início dos déficits intelectuais e adaptativos durante o período do desenvolvimento. Nota: O termo diagnóstico deficiência intelectual equivale ao diagnóstico da CID-11 de transtornos do desenvolvimento intelectual. Embora o termo deficiência intelectual seja utilizado em todo este Manual, ambos os termos são empregados no título para esclarecer as relações com outros sistemas de classificação. Além disso, uma Lei Federal dos Estados Unidos (Public Law 111-256, Rosa's Law) substitui o termo retardo mental por deficiência mental, e periódicos de pesquisa usam deficiência intelectual. Assim, deficiência intelectual é o termo de uso comum por médicos, educadores e outros, além do público leigo e dos grupos de defesa dos direitos. Especificar a gravidade atual: 317 (F70) Leve 318.0 (F71) Moderada 318.1 (F72) Grave 318.2 (F73) Profunda (APA, 2014, p.74).

São características essenciais da deficiência intelectual (transtorno do desenvolvimento intelectual) as que

incluem déficits em capacidades mentais genéricas e prejuízo na função adaptativa diária na comparação com indivíduos pareados para idade, gênero e aspectos 
socioculturais. O início ocorre durante o período do desenvolvimento. O diagnóstico de deficiência intelectual baseia-se tanto em avaliação clínica quanto em testes padronizados das funções adaptativa e intelectual (APA, 2014, p.74).

Existe um esforço, por parte dos manuais de diagnósticos, de construir um conceito mais amplo da deficiência intelectual e, nas suas sucessivas edições, tem-se buscado ir contra uma classificação no plano individual, numa concentração em inseri-los num plano sociocultural. Atualmente, há uma discussão sobre a necessidade ou não do diagnóstico clínico para o atendimento do aluno com deficiência intelectual, pois, a partir de 2011, mesmo os alunos sem diagnóstico clínico podem ser incluídos no Censo Escolar, precisando apenas do parecer do professor do Atendimento Educacional Especializado (Bridi \& Baptista, 2014).

Em termos educacionais, o diagnóstico, entre outros fatores, pode ser um elemento a ser considerado no trabalho docente, ajudandoo professor no seu planejamento. No entanto, de acordo com Anache (2001), isso não tem acontecido por existirem divergências em relação aos procedimentos e modelos educacionais na educação desses alunos.

No próximo capítulo, será feita uma explanação sobre educação inclusiva das pessoas com deficiência intelectual com um olhar sob a perspectiva histórico cultural, os desafios da inclusão e a formação dos professores que trabalham com estes sujeitos. 


\title{
Capítulo 2 - Os modelos pedagógicos e as políticas públicas de inclusão para o atendimento a pessoa com deficiência no Brasil
}

\author{
"Todo defeito cria estímulo para elaborar uma \\ compensação. Por isso o estudo dinâmico da \\ criança com deficiência não pode limitar-se a \\ determinar o nível e a gravidade da sua \\ insuficiência, mas deve incluir obrigatoriamente a \\ consideração dos processos compensatórios."
} (Vigotski, 1934-2012, p. 14, tradução nossa).

Como já abordado no Capítulo 1, a educação especial se pautava no modelo médico, pois a deficiência era abordada como doença e este ensino se configurava como uma educação paralela (Glat \& Fernandes, 2005). Na perspectiva de um ensino inclusivo, o paradigma médico constitui uma mudança e foi de grande importância, pois aproximou as pessoas com deficiência do restante da sociedade, o que representou o início de uma possibilidade de educação para todos. Dessa forma, podemos ver nessa iniciativa um dos primórdios do processo da educação inclusiva, ao enxergar possibilidades educacionais que o afastavam, reduzindo a exclusão.

De acordo com Platt (1999), ao longo da história da deficiência, observa-se que instituições e entidades estabeleceram políticas educacionais voltadas ao atendimento das pessoas com deficiência numa interação médico/terapêutica, assistencialismo/protecionismo. Augusto Comte, citado por Platt (1999), acreditava que o normal e o patológico são afirmados em relação ao conhecimento do normal e que as doenças nada mais são do que mudanças na ação dos estimulantes indispensáveis à saúde. Essa perspectiva, que só será absorvida posteriormente pelos modelos educacionais, relativizava as noções de normal versus anormal, indicando caminhos para pensar na educação especial como apenas mais uma das facetas do ensino, além de abrir possibilidades para pensar na inclusão como um dos aspectos da diversidade pedagógica.

Ainda nesse tema, Canguilhem (1982) atrela a noção de doença à incapacidade de produzir, dentro da ótica capitalista da normalidade, identificando a saúde naquilo que é útil. Essa discussão exemplifica a forma como a sociedade tratou as pessoas com deficiência durante muitos séculos, atribuindo anormalidade à doença e, dessa forma, a exclusão dos ditos anormais da sociedade, em termos produtivos. Assim, ele explica que:

Doente é um conceito geral de não-valor que compreende todos os valores negativos possíveis. Estar doente significa ser nocivo, ou indesejável, ou socialmente desvalorizado, etc. Inversamente, o que é desejado na saúde é evidente do ponto de vista 
fisiológico, e isso dá ao conceito de doença física um sentido relativamente estável. Os valores desejados são 'a vida, uma vida longa, a capacidade de reprodução, a capacidade de trabalho físico, a força, a resistência à fadiga, a ausência de dor, um estado no qual sente-se o corpo o menos possível, além da agradável sensação de existir. (p. 93)

Sobre isso, Câmara et al. (2012) argumentam que os conceitos estabelecidos sobre saúde e doença, ao longo do tempo, têm sido compreendidos de acordo com as diversas formas de existir das sociedades, em suas diferentes culturas e formas organizacionais. Seus significados são entendidos de acordo com a compreensão do ser em relação ao meio, variando com a cultura e o momento histórico; por isso se torna muito difícil formalizar um conceito sobre saúde e doença.

Nessa visão, Scliar (2007) também afirma que o conceito de saúde se insere em relação ao momento social, econômico, político e cultural, não representando o mesmo sentido para todas as pessoas, pois sua definição depende do local e da classe social. Juntamente com esse autor, que compartilha da definição elaborada por Canguilhem (1982), unem-se as autoras Silva (2008) e Coelho e Almeida Filho (2002), bem como Platt (1999), que asseveram que o conceito de normalidade/anormalidade é construído socialmente, tanto nos aspectos qualitativos quanto nos quantitativos. Tais conceitos estão imbricados à sociedade e à história - tanto em questões sociais, quanto políticas e econômicas - reproduzidos na forma de tratamento das pessoas com deficiência. Em resposta a isso, há uma luta constante dos sujeitos com deficiência para a revisão dessas noções, em prol de conquistas, em busca de uma posição que lhes foi usurpada pela sociedade, ao longo do tempo.

Em complemento aos conceitos já abordados, de acordo com a Organização Mundial da Saúde (OMS), saúde é definida como "um estado de completo bem-estar físico, mental e social e não somente ausência de afecções e enfermidades" (OMS, 1948). Porém, esse conceito vem sofrendo alterações, pois a OMS reconhece alguns fatores não médicos que alteram o estado de saúde, como a renda, o status social e educacional, o ambiente físico, as redes de apoio social, a genética, as questões de gênero, o comportamento social e as habilidades de enfrentar dificuldades (Souza, 2013).

Outro conceito ligado às questões de saúde e doença são as definições de normal e anormal, conforme sinalizamos anteriormente. No relato histórico sobre a deficiência intelectual, tais pessoas eram denominadas anormais, pois tal condição refletia-se no sentido médico de doença. Os anormais eram diferenciados dos normais, os quais eram entendidos como pessoas que não tinham nenhum tipo de defeito orgânico, mental, físico ou sensorial. Nesse sentido, Canguilhem (1982) aponta a ideia de normal, quando diz que 
O Dictionnaire de médecine de Littré e Robin define o normal do seguinte modo: normal (normalis, de norma, regra) que é conforme a regra, regular. ... É normal, etimologicamente - já que norma significa esquadro - aquilo que não se inclina nem para a esquerda nem para a direita. ... É normal aquilo que é como deve ser; e é normal, no sentido mais usual da palavra, o que se encontra na maior parte dos casos de uma espécie determinada ou o que constitui a média ou o módulo de uma característica mensurável. ... O equívoco foi facilitado pela tradição filosófica realista, segundo a qual toda generalidade é indício de uma essência, toda perfeição, a realização de uma essência e, portanto, uma generalidade observável de fato adquire o valor de perfeição realizada, um caráter comum adquire um valor de tipo ideal. Assinalamos, enfim, uma confusão análoga em medicina, em que o estado normal designa, ao mesmo tempo, o estado habitual dos órgãos e seu estado ideal, já que o restabelecimento desse estado habitual é o objeto usual da terapêutica.... Achamos que a medicina existe como arte da vida porque o vivente humano considera ele próprio como patológicos - e devendo, portanto, serem evitados ou corrigidos - certos estados ou comportamentos que, em relação à polaridade dinâmica da vida, são apreendidos sob forma de valores negativos. Achamos que, desta forma, o vivente humano prolonga, de modo mais ou menos lúcido, um efeito espontâneo, próprio da vida, para lutar contra aquilo que constitui um obstáculo à manutenção e ao seu desenvolvimento tomados como normas. (pp. 95-96)

Canguilhem (1982) aponta a ideia de anomalia, em contraponto à ideia de anormal, quando cita que

Anomalia vem do grego anomalia que significa desigualdade, aspereza; omalos designa, em grego, o que é uniforme, regular, liso; de modo que anomalia é, etimologicamente, anomalos, o que é desigual, rugoso, irregular. Anormal tornou-se um conceito descritivo e anomalia tornou-se um conceito normativo. ... Ser anormal consiste em se afastar, por sua própria organização, da grande maioria dos seres com os quais se deve ser comparado. ... As anomalias são classificadas segundo sua complexidade crescente e segundo sua gravidade crescente. ... O anormal não é o patológico. ... Patológico implica em pathos, sentimento direto e concreto de sofrimento e de impotência, sentimento de vida contrariada. Mas o patológico é realmente o anormal. ... Quando se diz que a saúde continuamente perfeita é anormal, expressa-se o fato da experiência do ser vivo incluir, de fato, a doença. Anormal quer dizer precisamente inexistente, inobservável. Portanto, isto não passa de outra maneira de dizer que a saúde contínua é uma norma e que uma norma não existe. Nesse sentido abusivo, é evidente que o patológico não é anormal. (pp. 101-103, 105-107) 
Sabe-se que a concepção de normal e anormal foi a base para se configurarem os processos e modelos educacionais. A educação de alunos com deficiência se baseava tradicionalmente num modelo segregado. Antes, a educação especial era vista como desnecessária e impossível, na qual os profissionais da educação não viam perspectivas de desenvolvimento e ingresso desses alunos na cultura. A partir dos anos 70, houve a institucionalização da educação especial, trazendo com isso novos métodos e técnicas de ensino que permitiam o aprendizado e o desenvolvimento destes alunos com deficiência. Com base nestas mudanças, houve uma transição do modelo médico para o modelo educacional. Contudo, os modelos e as técnicas adotados neste período dos anos 70, voltados para o comportamento, não foram suficientes para garantir o ingresso destes alunos no sistema educacional regular. Assim, as classes especiais continuaram servindo como modelos de ensino segregado (Glat \& Fernandes, 2005).

Esta situação muda a partir da segunda metade dos anos 90, quando o modelo de educação inclusiva ganha força com o advento da Declaração de Salamanca (1994), na qual se fundamenta uma proposta para que alunos com deficiência tenham acesso às escolas regulares e essas devem se adequar, garantindo o direito de educação para todos. A educação inclusiva é uma política voltada também para questões educacionais no atendimento de todos os alunos em suas especificidades.

A educação inclusiva, conforme sinalizamos no capítulo 1, é garantida por leis e documentos oficiais que orientam a criação de políticas públicas voltadas à formação de professores para este público, defendendo a premissa de educar a todos sem distinção. A inclusão é um processo ao qual a sociedade tem que se adaptar para que possa realmente incluir, possibilitando às pessoas com deficiência assumir seu lugar na sociedade. Incluir é conviver com as diferenças, transformando o sistema de ensino para respeitar as individualidades, buscando incluir todos os alunos nas atividades escolares (Resende, Ferreira, \& Rosa, 2010).

A discussão sobre a educação inclusiva promove discussões acerca da avaliação pedagógica, auxiliando o professor na implementação de ações que contribuam para sua prática. Também se faz necessário "melhorar os recursos materiais humanos das escolas e gerir eficientemente o sistema educacional" (Laplane, 2013, p. 9), organizando adequadamente o ensino para a nova realidade de um sistema inclusivo. Nesse sentido, enriquecer as ferramentas pedagógicas com materiais voltados à educação de pessoas com necessidades educacionais especiais, além de promover os mais diversos tipos de acessibilidade no ambiente escolar, desde o acesso aos banheiros até os itens da biblioteca escolar, são algumas das maneiras de transformar o espaço educacional em um ambiente realmente inclusivo e definitivamente preparado para receber o estudante. O planejamento da própria estrutura educacional do Estado 
(e do município, em certos casos) deve conter a previsão de recursos próprios para a promoção da inclusão, tanto em termos de formação docente quanto de recursos materiais e físicos.

Todas as questões apontadas acima tangenciam aspectos que envolvem o desenvolvimento da pessoa com necessidades especiais. Em razão disso, os estudos no campo da psicologia merecem destaque, como veremos a seguir.

\subsection{As ideias contemporâneas de Vigotski no campo da educação inclusiva da pessoa com deficiência intelectual}

A partir de 1900, o psicólogo francês Alfred Binet (1857-1911), com a colaboração de Théodore Simon (1872-1961), idealizou a primeira escala para a medida da inteligência geral, conhecida como escala Binet-Simon. O teste psicométrico de QI é uma classificação que pretende quantificar"o desempenho do indivíduo face a uma série de problemas e em referência aos resultados da distribuição amostral obtida junto de uma quantidade significativa de respondentes que refletem as características da população à qual o indivíduo pertence" (Sanches-Ferreira, Lopes-dos-Santos \& Santos, 2012, p. 555).

Esse teste é confundido com a própria inteligência, mas ele é basicamente a comparação entre idade mental e real da criança. A idade mental é determinada pelo número de tarefas do teste que a criança resolve corretamente. O QI é obtido quando se divide a idade mental pela cronológica (real) por cem. Dessa forma, quando a idade mental e a cronológica forem as mesmas, o QI será 100, estando na média; quando a idade mental for inferior à cronológica, o resultado será inferior a cem, indicando um QI abaixo da média, e se a idade mental for superior à idade cronológica, o QI será superior a cem, ou acima da média (Fontana \& Cruz, 1997).

Anache (2001) comenta que certos autores, como Vigotski (1934-2012) e Leontiev (1903-1979) (1991) criticavam os testes psicométricos para o diagnóstico da deficiência intelectual, pois tais testes pouco informavam sobre a criança, por desconsiderarem aspectos culturais. Para estes autores (Leontiev 1991; Vigotski, 1934-2012), o diagnóstico apenas quantitativo dos alunos produz encaminhamentos inadequados. A prática puramente quantitativa ignora aspectos sociais e históricos sobre a conceituação a respeito da deficiência e às capacidades de cada sujeito.

A teoria histórico-cultural impactou fortemente o estudo da educação especial. Nessa linha, admite-se o caráter sócio-histórico e cultural do ser humano, opondo-se radicalmente a uma visão biologizante da deficiência. Por isso, Vigotski concentrou seus estudos para 
explicações que vão além das características físicas e biológicas (Secretaria Municipal de Educação de São Paulo, 2008).

Para esta teoria, a educação escolar vem em primeiro plano e se faz necessária para o desenvolvimento humano de qualquer pessoa, pois ela possibilita transformações subjetivas que permitem à criança conquistar processos mais complexos de interação, comportamento e funcionamento intelectual. Afinal, o aprendizado adequado resulta em desenvolvimento (Vigotski, 1998). Por isso, a escola deve oferecer condições necessárias para a superação dos limites individuais.

As ideias de Vigotski foram difundidas no Brasil no final dos anos 80, representando uma alternativa teórica quando se destacava a importância da linguagem e do outro no desenvolvimento e na aprendizagem. Vigotski considera que o ser humano é resultado da transformação da cultura no aparato biológico - herdado da espécie. Para ele, era impossível considerar o desenvolvimento humano fora da sua historicidade, (Rigon, Asbahr, \& Moretti, 2010). Luria (1902-1977) (1991), outro autor desta abordagem teórica, afirma que o homem é diferente dos animais por três aspectos:

a) Primeiro: o homem não está obrigatoriamente preso às necessidades biológicas, pois ele se relaciona com o mundo e consigo mesmo a partir de necessidades intelectuais;

b) Segundo: a atividade consciente do homem não é determinada por impressões recebidas do meio, ou por experiência imediata, mas sim mediadas: indiretas;

c) Terceiro: a consciência forma-se pela assimilação da experiência acumulada no processo da história social da humanidade transmitida pela aprendizagem.

Importante salientar que, nos estudos da perspectiva histórico-cultural, entende-se que o homem difere dos animais, primeiramente, pelo preparo e emprego do instrumento de trabalho, exigindo conhecimento da operação a ser executada e da função do instrumento (Luria, 1991).

É por meio do trabalho que o ser humano se humaniza, possibilitando o desenvolvimento da cultura, sendo que a ruptura entre homens e animais não pode ser explicada apenas pela evolução biológica. Para que uma atividade se configure como humana, ela tem que ter uma intencionalidade, que é a capacidade de planejar as ações. O trabalho não modifica apenas aspectos biológicos, mas principalmente transforma o psiquismo. Por meio dele o homem controla seu comportamento e domina a natureza. (Moretti, Asbahr, \& Rigon, 2011).

A linguagem é um outro aspecto explicativo para a especificidade humana, pois ela é a estruturação da atividade consciente: formação das funções psicológicas superiores. Os signos, além de se constituírem como meio de comunicação - no qual o homem conserva e transmite 
informações e assimila experiências de gerações - envolvem também processos de abstração e generalização. Ou seja, a linguagem trouxe significativas transformações na reorganização da vivência emocional, de percepção e atenção, de memória, de imaginação, portanto, do pensamento (Luria, 1991). A linguagem é uma necessidade e condição para o desenvolvimento social e individual do homem, pois é por meio dela que o homem compartilha representações, conceitos, técnicas e os transmite às próximas gerações (Asbahr, 2005).

Influenciado pelos princípios do materialismo dialético, Vigotski buscou compreender os fenômenos como processos em movimento, sendo que todo fenômeno tem sua história, e essa história é caracterizada por mudanças qualitativas e quantitativas de desenvolvimento; transformações dos processos psicológicos elementares em processos complexos (Vigotski, 1984-2007).

De acordo com os pressupostos vigotskianos, "o sujeito humano é social desde o momento em que nasce e, por isso, está imerso, desde seus primeiros dias de vida, em um contexto social" (Kelman, 2010, p. 18). De tal forma, o psicólogo russo argumenta que o desenvolvimento humano "pressupõe uma natureza social específica e um processo através do qual as crianças penetram na vida intelectual daqueles que a cercam” (Vigotski, 2008, p. 101).

No desenvolvimento da criança, portanto, é possível observar um princípio norteador: a lei genética geral do desenvolvimento cultural, na qual aparecem dois planos: a) o plano social, entre pessoas, que é interpsicológico e; b) o plano individual, que ocorre no interior da criança: nível intrapsicológico (Pino, 2005). A transformação de algo cultural para o campo individual se dá por meio do processo de internalização conforme será descrito a seguir:

Todas as funções no desenvolvimento da criança aparecem duas vezes: primeiro, no nível social, e, depois, no nível individual; primeiro, entre pessoas (interpsicológica), e, depois, no interior da criança (intrapsicológica). Isso se aplica igualmente para a atenção voluntária, para memória lógica e para formação de conceitos. Todas as funções superiores originam-se das relações reais entre indivíduos humanos.... A internalização das atividades socialmente enraizadas e historicamente desenvolvidas constitui o aspecto característico da psicologia humana; é a base do salto quantitativo da psicologia animal para a psicologia humana. (Vigotski, 1984-2007, p. 57-58)

Assim sendo, todo desenvolvimento cultural se organiza em torno de três eixos principais: em si, para os outros e para si. "É através do outro que nos constituímos" (Vigotski, 1929-2000, p. 24). Tudo o que foi internalizado antes foi externo, social: uma relação entre pessoas. Vigotski (1929-2000) afirma, sobre a personalidade do homem, que "a personalidade se torna, para si, aquilo que ela é em si, através daquilo que ela antes manifesta como seu em si 
para os outros" (p. 24). Assim sendo, "a personalidade é o conjunto de relações sociais" (p. 35). Deste modo, tudo que é interno foi externo, pois "as funções psíquicas superiores criam-se no coletivo" (p. 35).

O papel do outro, das relações sociais, o desenvolvimento cultural da criança e a internalização das atividades sócio-históricas etc. são conceitos fundamentais que Vigotski abordou na perspectiva histórico-cultural e importantes para adentramos nos estudos de defectologia. Em tais estudos, Vigotski aponta caminhos de natureza prática e teórica, orientando propostas para a educação da criança com deficiência (Padilha, 2004).

Nesse contexto, os estudos sobre defectologia ${ }^{9}$ realizados por Vigotski têm como objetivo principal compreender o desenvolvimento psicológico de crianças com peculiaridades no desenvolvimento. Tais estudos buscaram entender os aspectos da gênese do funcionamento psicológico superior e atender a uma demanda social de crianças com deficiências em condições vulneráveis na União Soviética pós-revolução. Vigotski, então, criou o Instituto Experimental de Defectologia, em 1929, para estudar as necessidades educacionais destas crianças (Nuernberg, 2008).

Vigotski criticava a defectologia tradicional, por ter uma perspectiva quantitativa da deficiência, na qual mensurava a incapacidade da criança considerada deficiente em uma conceituação aritmética das somas dos defeitos; já discutimos isso anteriormente. Esta defectologia tradicional era considerada, por ele, como uma pedagogia menor, pois se restringia a uma concepção puramente quantitativa do desenvolvimento infantil, com ênfase nas pesquisas de caráter anatômico e fisiológico. Para ele, tal maneira de abordar a deficiência também se desdobrava na pedagogia prática: a ideia de um ensino reduzido e mais lento para estas pessoas (Cunha, Cunha,\& Ayres, 2013).

\footnotetext{
${ }^{9} \mathrm{~A}$ defectologia foi uma área de estudo iniciada no fim do século XIX e início do século XX, no contexto da Rússia/ União Soviética (Barroco, 2007).

O termo defektologiia surgiu em 1912, elaborado pelo psiquiatra russo Vsevolod Petrovich Kashchenko (1870-1943). Esse termo é de origem ocidental e tinha como meta diferenciar crianças especiais, com as quais o referido psiquiatra trabalhava, de outras crianças especiais ou superdotadas. O termo "defeituoso" não ia na direção de possível entendimento de preconceito, sendo que alguns autores utilizavam o termo defektivnii. Por volta de 1920, Vigotski e seus colaboradores desenvolveram uma psicologia fundamentada no Materialismo Histórico Dialético que trouxe contribuições para o estudo da criança com deficiência. Contudo a defectologia antiga era marcada exclusivamente para o estudo das limitações das pessoas com deficiência e Vigotski introduz uma nova prática que ele denomina de defectologia moderna, com o intuito de introduzir instrumentos culturais especiais e adaptados, como também procedimentos pedagógicos especiais no trabalho com as crianças com deficiência (Neto \& Leal, 2013). As investigações de Vigotski sobre a educação e o desenvolvimento da pessoa com deficiência foram consideradas referências para a constituição da defectologia na União Soviética (Barroco, 2007).

A defectologia é um campo de estudo que pesquisa as pessoas que apresentam algum tipo de "defeito" aqueles que não se enquadram nos parâmetros da normalidade. Seja sob uma condição física, seja sob uma condição psicológica (Cunha, Cunha, \& Silva, 2013).
} 
Diante disso, Vigotski abre um novo olhar para a defectologia, pautando-se em aspectos qualitativos do desenvolvimento. Para o autor, as crianças com deficiência apresentam um processo qualitativamente distinto e peculiar se comparadas às demais, mas elas não são menos competentes (Cunha, Cunha,\& Ayres, 2013; Vigotski, 1934-2012). A defectologia, termo utilizado à época, deveria focar nas capacidades das crianças, não nas suas limitações. Para ele, todo o defeito cria os estímulos para uma compensação e a intervenção pedagógica ou clínica não pode se limitar a determinar o nível e a gravidade da insuficiência, deve se voltar para os processos compensatórios do desenvolvimento e a conduta da criança, os quais estão em andamento em razão das demandas culturais que as circundam (Vigotski, 1934-2012).

Vigotski (1934-2012) afirma que, diante do impedimento de um órgão ou uma função, o sistema nervoso central e o psíquico assumem a tarefa de compensar o funcionamento dificultado desse órgão. Se o ser humano tem uma determinada deficiência, o desenvolvimento psíquico, de origem social, orienta-se na direção oposta àquela deficiência. Para realizar esses estudos, Vigotski se baseou na teoria da compensação a partir de W. Stern e A. Adler, além, também, das suas próprias considerações e contribuições sobre o tema. (Cunha, Ayres, \& Moraes, 2010).

Nesse sentido, o limite biológico não é determinante para o não desenvolvimento da criança com deficiência, mas a sociedade pode criar estes limites. Para Vigotski e pesquisadores da perspectiva histórico-cultural, não é o defeito orgânico que determina o grau de deficiência ou não deficiência, mas as consequências sociais e sua relação sociopsicológica. A criança não se vê como uma pessoa com deficiência, mas a sociedade a coloca em uma posição social inferior. A criança também não sente diretamente sua deficiência, mas percebe suas dificuldades nos encontros sociais: o defeito só se torna deficiência quando a criança é impedida de participar da vida social (Cunha, Ayres, \& Moraes, 2013; Vigotski, 1934-2012).

No processo de compensação, não se trata de substituição de órgãos ou funções por outros, mas a busca de meios de desenvolvimento culturais para transformação psíquica. Contudo, para o autor, o ser Sistema Nervoso Central é plástico por funcionar simbolicamente e segundo condições histórico-culturais. Por meio delas é que se dá a compensação do defeito orgânico (Barroco, 2007; Cunha, Cunha, \& Ayres, 2013; Padilha, 2004; Vigotski, 1934-2012).

Vigotski (1934-2012) afirma que a compensação pode ter dois resultados: a vitória e a derrota. Mas, independentemente disso, em todas as circunstâncias, o desenvolvimento agravado pelo defeito constitui um processo orgânico e psicológico de criação e recriação da personalidade da criança. Nesse processo, estão apresentados: a reorganização (ou não) das funções adaptativas, a formação (ou não) de novos processos gerados pelo defeito e a abertura (ou não) de novos caminhos. 
Nessa direção, Vigotski (1934-2012) assegura que a criança com deficiência segue as mesmas leis gerais do desenvolvimento da criança sem deficiência, considerada normal. Mas esse desenvolvimento se dá de forma distinta, por outro caminho, com outros meios. Para o pedagogo, é importante conhecer esses caminhos distintos pelo qual deve-se conduzir a criança, e a chave para isso está na "lei de transformação de menos defeito em mais compensação" (Vigotski, 1934-2012, p. 17, tradução nossa).

Portanto, a educação da criança com deficiência deve se basear na potencialidade. Dessa forma, o professor deve ter a compreensão não somente do defeito da criança, mas do seu desenvolvimento, direcionando-se para uma formação cultural do homem e suas funções psíquicas superiores (Cunha, Ayres, \& Moraes, 2010; Vigotski, 1934-2012).

Vigotski era crítico às escolas especiais, pois elas apresentavam um programa curricular reduzido ou métodos facilitados em comparação às escolas comuns. Para ele, a escola deveria ter uma tarefa de criação positiva que respondesse às peculiaridades de seus educandos, afrontando os defeitos e não se adaptando a eles (Lima, Araújo, \& Moraes, 2010; Vigotski, 1934-2012). Nesse sentido, Vigotski (1934-2012) afirma

Não devemos nos conformar mais com o fato de que na escola especial se aplique simplesmente o programa reduzido da escola comum, nem com seus métodos facilitados e simplificados. A escola especial se encontra em oposição à tarefa de uma criação positiva, de gerar formas de trabalho próprias que respondam à peculiaridade de seus educandos. (p. 33; tradução nossa)

Para Beyer (2005), Vigotski talvez tenha sido o primeiro pensador que abordou conceitos centrais da ideia de inclusão, pois ele partiu de uma premissa básica da teoria sóciohistórica, como condição fundamental, na qual a criança passa por transformações que a tornam capaz de desenvolver estruturas humanas de pensamento e de linguagem, que estão apoiadas em interações sociais e, porque não dizer, mediações pedagógicas qualificadas (Medeiros \& Cabral, 2006). De fato, o grande problema da criança com deficiência está no isolamento, em vários âmbitos da vida em sociedade. Para Vigotski, a dinâmica sociogênica da personalidade, para um desenvolvimento pleno, é imprescindível.

Dessa forma, os estudos sobre o desenvolvimento humano na perspectiva históricocultural elaboram meios teóricos e conceituais para se problematizar a importância da inclusão. Daí advém a relevância de um estudo articulado com as políticas públicas e os processos de inclusão escolar como decisórios para o desenvolvimento dessas pessoas. Aqui, pelos motivos explicados anteriormente, será enfatizada a situação das pessoas com deficiência intelectual. 


\subsection{Educação e sala de aula: os desafios da inclusão do aluno com deficiência intelectual}

Conforme explicado anteriormente, limitar-se a uma prática de atividades curriculares menos complexas não favorece o desenvolvimento da pessoa com deficiência intelectual. Muitas crianças desenvolvem baixas expectativas de aprendizagem e se sentem excluídas do convívio social e escolar (Kassar, 2013). Suas vidas, portanto, giram em torno da limitação ou incapacidade, não sendo consideradas suas potencialidades e aptidões (Reis \& Ross, 2008).

Portanto, o grande desafio para que ocorra a educação inclusiva do aluno com deficiência intelectual está em uma reestruturação do trabalho pedagógico e de suas mediações (Silva, Ribeiro, \& Mieto, 2010), de forma que essa mediação possibilite a promoção de novas interações na produção do conhecimento e um devido planejamento da adequação curricular. Diante destes fatos, Padilha (2004) afirma que:

O professor [deve] interagir com os alunos, de modo que torne a sala de aula um espaço onde o conhecimento pode ser efetivamente partilhado (p. 68) ... Não se está negando que algumas crianças tenham necessidades especiais e, portanto, exijam mediações especiais para sua constituição enquanto aprendizes. À escola cabe, porém, dispor de recursos e procedimentos não uniformes para que os alunos tenham possibilidades de caminhar além de seus limites. (p. 77)

Dessa forma, o professor precisa ter ferramentas adequadas para trabalhar com o aluno com deficiência, a fim de possibilitar a essas crianças transformar conceitos cotidianos em científicos, desenvolvendo os pensamentos categóricos/conceituais. Conforme discutimos anteriormente, isso só é possível por meio de mediações pedagógicas específicas, baseadas em estratégias pedagógicas que valorizem os processos interativos, incluindo a criança no contexto da produção de conhecimento na sala de aula inclusiva (Silva, Ribeiro,\& Mieto, 2010).

Nesse sentido, o paradigma inclusivo, ao valorizar as experiências sociais coletivas tem o potencial de propiciar à pessoa com deficiência a construção de novos significados sobre si e sobre o mundo. Nesse ínterim, a escola ocupa uma importante função mediadora, pois é uma das instâncias responsáveis pela construção da autonomia do sujeito, que está associada aos fatores interligados com a estrutura da deficiência, à constituição orgânica e subjetiva da pessoa, sua vivência e suas condições socioambientais (Dias, 2014).

\subsection{Delimitação do problema: os desafios das políticas educacionais e a formação docente}


De acordo com várias pesquisas existentes no âmbito da inclusão escolar de alunos com deficiência intelectual, é possível identificar que as políticas inclusivas têm sido implementadas de forma gradual e contraditória, ancoradas pelas legislações vigentes em dissonância com as condições objetivas das escolas (Dainêz, 2009; Oliveira \& Leite, 2007; Teles, 2010).

Nesse contexto, há pesquisas que se voltam para a formação do professor e seu papel diante das políticas de inclusão implementadas nas escolas (Dainêz, 2009; Fonseca, 2011; Lopes, 2005; Mendonça, 2013; Nicolau, 2011; Oliveira \& Leite, 2007; Tedde, 2012; Teles, 2010; Veltrone, 2011). Tais pesquisas têm mostrado que o profissional da educação não se sente capaz para o trabalho de inclusão, e isso se dá, na maioria das vezes, pela falta de conhecimentos necessários para os fundamentos que permeiam o sistema inclusivo e aspectos relacionados ao desenvolvimento do aluno.

Teles (2010) afirma, em sua pesquisa, que os professores se encontram num embate entre os significados da deficiência (como impedimento para o desenvolvimento) e os processos de escolarização destes alunos. Ou seja, ela demonstra que existem nas escolas regulares educadores despreparados para receber a criança com deficiência intelectual, não reconhecendo suas potencialidades e tampouco entendendo suas especificidades.

A postura do educador é importante para efetiva inclusão da criança com deficiência intelectual. De acordo com Dainêz (2009), embora ocorram esforços dos professores para promoção da aprendizagem do sujeito com deficiência intelectual, há uma ênfase no ensino individualizado. Muitas vezes, as crianças com alguma deficiência não participam efetivamente das interações pedagógicas em sala de aula. Elas também se deparam com momentos que desfavorecem a superação de suas dificuldades, acentuando e agravando sua deficiência.

O ensino diferenciado centra-se em função da individualização do atendimento educacional, na medida em que reflete a distinção existente no repertório comportamental de cada aluno. A professora não privilegia atividades em grupo, cada aluno é incentivado a se preocupar somente com a sua atividade. Podemos dizer que o educador centra sua atenção em sujeitos particulares, dando uma conotação de ensino individualizado. (Dainêz, 2009, p. 135-136).

Isso ocorre, na opinião da pesquisadora, por causa do despreparo do profissional. Por isso, há necessidade de que os esforços do educador venham acompanhados de uma formação adequada para que a prática da educação inclusiva possa promover a aprendizagem mais efetiva e a promoção do desenvolvimento das crianças incluídas.

No atual momento, o processo inclusivo está alicerçado em bases teóricas fundamentadas na igualdade e diversidade, bem como nos estudos das legislações e dos 
decretos. Porém, o questionamento deve se voltar também para o modo como está acontecendo a prática inclusiva nas escolas.

Oliveira e Leite (2007) afirmam em seus estudos que, muitas vezes, a prática inclusiva tem se distanciado das proposições legais. Há um questionamento nas esferas administrativas e pedagógicas acerca da eficácia das políticas públicas de inclusão oferecidas às crianças com deficiência intelectual, com o objetivo de promover o desenvolvimento humano.

Pletsch (2009), por sua vez, realizou uma pesquisa com foco na formação de professores para a educação inclusiva no Brasil, na qual tomou como base as diretrizes políticas sobre educação inclusiva e a legislação nacional. A autora conclui que os professores possuem um sentimento de incapacidade diante do ingresso de um aluno com necessidades educativas especiais na sua sala de aula, seja por falta de preparo ou de informação, o que dificulta o desenvolvimento de uma experiência pedagógica que realmente propicie uma educação adequada ao aluno. Portanto, é necessário que a formação de docentes contribua para um ensino focado na diversidade, por meio de um currículo amplo, voltado para atitudes inclusivas.

Ainda Pletsch (2014), em uma outra pesquisa, discutiu a implementação das políticas de inclusão escolar no Rio de Janeiro, após as mudanças associadas à Política Nacional de Educação Especial na Perspectiva da Educação Inclusiva e às Diretrizes Operacionais do Atendimento Educacional Especializado na Educação Básica, modalidade Educação Especial. Como conclusão dessa investigação, a autora indica que as diretrizes educacionais vigentes ainda são ingênuas acerca da forma de atendimento aos alunos com deficiência, por sua incapacidade de real aplicação no contexto local e por sua inaptidão em realizar um atendimento coerente às necessidades apresentadas pelos alunos.

Sendo assim, na proposta inclusiva, todos os alunos, não somente aqueles com necessidades educacionais específicas, devem ser inseridos no ensino regular e apoiados por todos os atores do sistema educacional. Avesso à noção de normatização, o processo de inclusão deve focalizar as possibilidades de cada um, buscando as condições que favoreçam a permanência e o desenvolvimento dos estudantes (Kohatsu, 2003).

Diante dessas contribuições, a presente pesquisa volta-se para análise do processo de inclusão escolar dos últimos vinte anos na rede pública de ensino do Distrito Federal. Pretendeu-se investigar, por meio de narrativas dos docentes, o impacto das políticas públicas inclusivas implementadas pelo Distrito Federal e os desafios pedagógicos delas decorrentes. Desta forma, a presente investigação questiona: o que narram os professores sobre o processo de inclusão dos alunos com deficiência intelectual implementado nos últimos vinte anos no Distrito Federal; quais os desafios pedagógicos dele decorrentes? 


\subsection{Objetivo Geral}

Analisar as narrativas dos professores da rede pública de ensino no Distrito Federal sobre o processo de inclusão dos alunos com deficiência intelectual implementado nos últimos vinte anos e os desafios pedagógicos dele decorrentes.

\subsubsection{Objetivos específicos}

- Analisar as relações entre políticas de inclusão implementadas pela Secretaria de Educação do Distrito Federal - nos últimos vinte anos - e o impacto nas dinâmicas educativas envolvendo o professor de alunos com deficiência intelectual.

- Identificar, a partir das políticas de inclusão implementadas pela Secretaria de Educação do Distrito Federal - nos últimos vinte anos - os desafios pedagógicos docentes na atuação com o aluno com deficiência intelectual. 


\section{Capítulo 3 - Metodologia}

"O sentimento ou a consciência da menosvalia, que surge no indivíduo em consequência do 'defeito', está na valorização de sua posição social e esta se converte na principal força motriz do desenvolvimento psíquico." (Vigotski, 1934-2012, p. 4, tradução nossa).

\subsection{Método}

A metodologia do presente trabalho se baseia em uma pesquisa qualitativa, utilizando-se da realização de entrevistas semiestruturadas para analisar as narrativas dos professores acerca dos processos de inclusão nas escolas públicas do Distrito Federal, nos últimos vinte anos, aproximadamente.

Nos pressupostos da pesquisa qualitativa, a realidade social é compreendida na edificação de significados produzidos nos processos de relações concretas. Para tanto, o foco está no processo e na reflexão dos dados voltados para a produção dos significados. A pesquisa qualitativa é uma forma de dar visibilidade às pessoas e suas produções sociais (Bauer \& Gaskell, 2000). Ela não estabelece previamente definição de hipóteses formais, pois o maior esforço está em evidenciar o curso da investigação. É, portanto, um processo.

Essa forma de pesquisar caracteriza-se pela ausência de medidas numéricas e análises estatísticas, considerando aspectos mais profundos e subjetivos do estudo. Para estudar métodos qualitativos, é preciso aprender a observar, registrar e analisar interações reais entre pessoas e sistemas. De fato, existem possibilidades mais efetivas de proporcionar um conhecimento aprofundado e subjetivo do participante da pesquisa. Os métodos qualitativos são menos monolíticos, cabendo um relacionamento mais extenso e flexível entre pesquisador e pesquisado, enfrentando informações mais subjetivas, amplas e com riqueza de detalhes, se comparado aos métodos quantitativos (Dias, 2000).

A expressão do participante é favorecida pelos instrumentos utilizados e análise das informações. A pesquisa qualitativa tem um caráter interpretativo-construtivo, indicando que pesquisador e participante erguem conjuntamente os significados em volta do tema da pesquisa. Nessa linha, a entrevista semiestruturada é comumente utilizada como procedimento de construção de dado investigativo. A partir dela, é possível estabelecer um processo social entre 
interlocutores - entrevistado e entrevistador - que visa a produção de um conhecimento. $\mathrm{O}$ discurso, portanto, é o principal meio de construção dos dados. Nessa interação, ocorre uma troca de ideias e significados em que várias percepções e realidades são desenvolvidas e reveladas colaborativamente (Bauer \& Gaskell, 2000).

Martins (2015) apresenta características básicas que constituem a pesquisa qualitativa; uma delas é que o ambiente natural é importante para se obter a base dos dados investigados, pois permite que o pesquisador tenha um contato prolongado com o campo de estudo. Outra característica é o caráter descritivo das investigações, pois tem a função de apreender os dados nas suas relações com o contexto. O pesquisador tem que estar atento ao maior número de elementos do campo estudado. Uma terceira característica se pauta na pesquisa que se volta para o processo, como dito anteriormente.

É de grande importância que o pesquisador se submeta ao campo real, pois buscar compreender e interpretar a realidade é uma atitude fundamental na pesquisa. Há, nesse tipo de pesquisa, a preocupação de uma análise qualitativa dos dados, pois instaura uma comparação com a teoria estudada. Outro ponto importante está no pesquisador se colocar no lugar do outro, entendendo os dados por seu ponto de vista; o pesquisador deve ser uma figura física e emocional no contexto da investigação para que possa chegar às descrições objetivas e complexas alcançadas do objeto em estudo (Martins, 2015).

Buscando privilegiar a emergência das falas docentes, decidiu-se pela entrevista semiestruturada para o desenvolvimento investigativo, por ser um tipo de instrumento que possibilita um roteiro mais flexível, no qual o entrevistado assume um papel ativo nas informações. Aqui, o entrevistador se coloca na posição de problematizador e mediador das narrativas e ambos são convidados a pensar sobre a qualidade dos dados (Abreu, 2015).

Para Abreu (2015), esse tipo de entrevista coloca o entrevistado como autor de suas narrativas, possibilitando-lhe descrever sua história, com situações que ele vivencia ou vivenciou. No momento de sua narrativa, o entrevistado pode refletir sobre suas práticas, seu percurso de vida, sobre sua cultura e relações sociais. Portanto, a entrevista semiestruturada permite que a história seja constituída pelas narrativas e pelos participantes. Assim, de acordo com Moreira (2015), "narrador e ouvinte são, ambos, sujeitos ativos na constituição de uma mesma troca ou drama, sendo frágil o limite que define um e outro" (p. 78).

\subsubsection{Características do trabalho de campo}

O presente trabalho foi submetido e aprovado pelo Comitê de Ética, parecer número1.793.971 (Anexo A). Após a aprovação foram iniciadas as entrevistas aos professores 
que aceitaram fazer parte desta pesquisa. Todos assinaram o termo de concordância livre e esclarecido (TCLE) (Anexo B).

Foram escolhidos seis professores com idade entre 36 e 55 anos, do Ensino Fundamental, Séries Iniciais, da rede pública do Distrito Federal, que trabalharam com a inclusão de alunos com deficiência intelectual nos últimos vinte anos. Os professores selecionados participaram da implementação das políticas públicas de inclusão e da ministração de aulas para esse público.

Em seguida, foram realizadas entrevistas semiestruturadas individuais contendo perguntas amplas e gerais sobre questões da inclusão, do aluno com deficiência intelectual e das políticas públicas sobre inclusão (Apêndice A), de modo a enfatizar as concepções docentes sobre o processo inclusivo e seu impacto nas relações de ensino-aprendizagem. A partir das respostas dos participantes, foram adicionadas novas perguntas, permitindo que os participantes pudessem narrar suas ideias de forma ainda mais espontânea, possibilitando ao pesquisador um melhor entendimento sobre a temática abordada.

Todo o procedimento investigativo do trabalho de campo perdurou três meses do ano de dois mil e dezesseis, no qual ocorreram os primeiros contatos com as participantes, as escolhas articuladas com o perfil de professores que atuaram aproximadamente durante vinte anos com inclusão. Neste período foram realizadas também as entrevistas, transcrição e análise preliminar dos dados.

Para construção analítica dos dados foram utilizadas as transcrições dos dados articuladas à composição de um diário de campo. Cada entrevista teve um tempo médio de uma hora de gravação, com um total de seis horas e onze minutos de entrevistas gravadas.

\subsubsection{Perfil dos participantes}

\section{Participante 1}

\begin{tabular}{|c|c|c|c|}
\hline NOME & IDADE & $\begin{array}{c}\text { TEMPO DE } \\
\text { DOCÊNCIA }\end{array}$ & \multicolumn{1}{c|}{ INFORMAÇÕES ADICIONAIS } \\
\hline Orquídea & 36 & 18 & $\begin{array}{l}\text { - Formação: Filosofia, Pedagogia e Teologia; } \\
\text { - Formação continuada: Várias pós-graduações e um } \\
\text { mestrado fora do Brasil (não é reconhecido no Brasil - }\end{array}$ \\
\hline
\end{tabular}




\begin{tabular}{|l|l|l|}
\hline & $\begin{array}{l}\text { em Educação); } \\
\text { - Hoje é professora do CEEDV }{ }^{10} ; \\
\text { - Trabalha na SEEDF na Regional do Plano Piloto; } \\
\text { - Relata que deu aula para alunos com dificuldades de } \\
\text { aprendizagem desde o início da carreira; } \\
\text { - Trabalhou por muito tempo com educação precoce; } \\
- \text { Fazia avaliação dos alunos da educação precoce para } \\
\text { serem incluídos em escolas de educação infantil na } \\
\text { integração inversa }{ }^{11} .\end{array}$ \\
\hline
\end{tabular}

\section{Participante 2}

\begin{tabular}{|l|c|c|l|}
\hline NOME & IDADE & $\begin{array}{c}\text { TEMPO DE } \\
\text { DOCÊNCIA }\end{array}$ & \multicolumn{1}{c|}{ INFORMAÇÕES ADICIONAIS } \\
\hline Açucena & 51 & $\begin{array}{c}28 \text { anos e } \\
\text { meio }\end{array}$ & $\begin{array}{l}\text { - Formação: Magistério e Pedagogia; } \\
\text {-Formação continuada: Pós-graduação em Psicopedagogia } \\
\text { e Pós-graduação na Avaliação da aprendizagem - UnB; } \\
\text { - Professora aposentada; } \\
\text { - Trabalhou na SEEDF na Regional de Ceilândia. }\end{array}$ \\
\hline
\end{tabular}

${ }^{10}$ CEEDV - Centro de Ensino Especial de Deficientes Visuais.

11 Integração Inversa - II - O DECRETO No 22.912, DE 25 DE ABRIL DE 2002 DODF DE 26.04.2002 institui que os alunos com deficiência podem ser atendidos em Classes de Integração Inversa, cuja constituição obedeça à proporção de $1 / 3$ de alunos normais, nas áreas de Deficiência Mental, Deficiência Auditiva, Deficiência Física e Condutas Típicas de Síndromes. Classe constituída por estudantes com Deficiências e/ou Transtorno Global do Desenvolvimento (TGD). O estudante poderá permanecer em turma de Integração Inversa pelo período em que dela necessitar nos anos iniciais do Ensino Fundamental, conforme previsto no Estudo de Caso/Adequação Curricular, com a participação do professor regente, da Equipe de Apoio à Aprendizagem, do Serviço de Orientação Educacional e da Sala de Recursos, visto não se tratar de necessidade transitória (Estratégia de matrícula de 2016). 


\section{Participante 3}

\begin{tabular}{|c|c|c|c|}
\hline NOME & IDADE & $\begin{array}{l}\text { TEMPO DE } \\
\text { DOCÊNCIA }\end{array}$ & INFORMAÇÕES ADICIONAIS \\
\hline Violeta & 38 & 19 & $\begin{array}{l}\text { - Formação: Magistério e Pedagogia; } \\
\text { - Formação continuada: Pós-graduação em Inclusão } \\
\text { Escolar-UnB; } \\
\text { - Trabalha na SEEDF na Regional Ceilândia; } \\
\text { - Hoje é Pedagoga da Equipe de Aprendizagem } \\
\text { Especializada. }\end{array}$ \\
\hline
\end{tabular}

\section{Participante 4}

\begin{tabular}{|c|c|c|c|}
\hline NOME & IDADE & $\begin{array}{l}\text { TEMPO DE } \\
\text { DOCÊNCIA }\end{array}$ & INFORMAÇÕES ADICIONAIS \\
\hline Tulipa & 46 & 26 & $\begin{array}{l}\text { - Formação: Magistério e Pedagogia; } \\
\text { - Formação continuada: Mestre em Tecnologias } \\
\text { Educacionais - UnB; } \\
\text { - Trabalhou na SEEDF na Regional de Ceilândia; } \\
\text { - Hoje é professora readaptada (por problemas na voz), } \\
\text { atuando na sala de informática. } \\
\text { - Começou a trabalhar com alunos com deficiência desde o } \\
\text { estágio quando fazia o magistério, mas já como professora } \\
\text { trabalhou com as pessoas com deficiência na sala de } \\
\text { informática, com alunos DI incluidos. }\end{array}$ \\
\hline
\end{tabular}

Participante 5

\begin{tabular}{|l|l|l|l|}
\hline NOME & IDADE & $\begin{array}{c}\text { TEMPO DE } \\
\text { DOCÊNCIA }\end{array}$ & INFORMAÇÕES ADICIONAIS \\
& & \\
\hline
\end{tabular}




\begin{tabular}{|c|c|c|c|}
\hline Gardênia & 55 & 22 & $\begin{array}{l}\text { - Formação: Magistério e Pedagogia; } \\
\text { - Formação continuada: Orientação Educacional; } \\
\text { - Trabalha na SEEDF na Regional de Samambaia, e } \\
\text { atualmente, na Regional da Ceilândia; } \\
\text { - Hoje é pedagoga da Equipe de aprendizagem } \\
\text { especializada e Orientadora Educacional. }\end{array}$ \\
\hline
\end{tabular}

\section{Participante 6}

\begin{tabular}{|c|c|c|l|}
\hline NOME & IDADE & $\begin{array}{l}\text { TEMPO DE } \\
\text { DOCÊNCIA }\end{array}$ & \multicolumn{1}{|c|}{ INFORMAÇÕES ADICIONAIS } \\
\hline Rosa & 45 & 23 & $\begin{array}{l}\text { - Formação: Magistério e Pedagogia para séries iniciais; } \\
\text { - Formação continuada: Pós-graduação em Educação } \\
\text { Ambiental; }\end{array}$ \\
& $\begin{array}{l}\text { - É da SEEDF, onde trabalhou nas Regionais de Santa } \\
\text { Maria, Taguatinga e Ceilândia; } \\
\text { - Hoje trabalha na escola atuando no } 3^{\circ} \text { ano. }\end{array}$ \\
\hline
\end{tabular}

A análise e discussão dos dados foram baseadas nos objetivos norteadores e na construção das entrevistas com os professores que atuaram desde a implementação do processo inclusivo na rede pública do Distrito Federal, em salas inclusivas com deficiência intelectual.

Foram identificados dois eixos importantes para a análise dos dados:

- Eixo A: As políticas de inclusão implementadas pela SEEDF e o impacto das mesmas na escola;

- Eixo B: O aluno com deficiência intelectual e as estratégias pedagógicas utilizadas pelos professores na educação inclusiva ao longo das últimas duas décadas. 


\section{Capítulo 4 - Análise e discussão dos dados}

“As crianças com 'defeito' se desenvolvem de modo distinto, com outros meios, e para o pedagogo é importante conhecer a peculiaridade do caminho pelo qual deve conduzir a criança. A chave da peculiaridade se deve à lei da transformação de menos defeito e mais compensação." (Vigotski, 1934-2012, p. 17, tradução nossa).

O trabalho pedagógico nas escolas públicas é orientado pelas políticas públicas educacionais desenvolvidas pelo Ministério da Educação (1994). Nestes últimos vinte anos, aproximadamente, as instituições educacionais brasileiras têm vivenciado a realidade da política pública da educação inclusiva. Os professores, ao longo desses anos, foram apresentados aos princípios da inclusão escolar. No entanto, houve muitas resistências e incompreensões, principalmente por parte do corpo docente, conforme aponta a bibliografia especializada (Kassar, 2011, 2014; Padilha, 2015; Pletsch, 2009, 2014, entre outros).

Sabe-se que o direito à escola é universal, conforme versa a Constituição Federal de 1988 e, após a constituinte, ocorreu um amadurecimento das políticas públicas brasileiras devido ao fortalecimento da democracia (Kassar, 2011). Nessa linha, a perspectiva da educação inclusiva apresenta-se como um princípio ético-político que direciona as relações humanas para produção de uma sociedade mais igualitária e participativa, respeitando diferenças e oportunizando direitos iguais e inalienáveis. O artigo do MEC/SECADI indica que

O movimento mundial pela educação inclusiva é uma ação política, cultural, social e pedagógica, desencadeada em defesa do direito de todos os estudantes de estarem juntos, aprendendo e participando, sem nenhum tipo de discriminação. A educação inclusiva constitui um paradigma educacional fundamentado na concepção de direitos humanos, que conjuga igualdade e diferença como valores indissociáveis, e que avança em relação à ideia de equidade formal ao contextualizar as circunstâncias históricas da produção da exclusão dentro e fora da escola. (Ministério da Educação/SECADI, 2013, p. 1)

No entanto, conforme se observa no panorama apresentado pelas entrevistas realizadas para este trabalho, a inclusão não chegou às escolas ao mesmo tempo nem com a clareza necessária para que houvesse uma boa aceitação e um claro entendimento por parte da comunidade escolar. Por isso, concordamos - com Jesus e Effgen (2012) - que são necessárias 
reflexões acerca da educação, dos processos de inclusão-exclusão, das políticas educativas, das condições de aprendizado e da formação do docente para que se cumpra adequadamente o princípio ético da inclusão escolar.

Desta forma, a presente pesquisa realizou análise e discussão dos dados baseadas nos objetivos norteadores e na construção das entrevistas com os professores que atuaram desde a implementação do processo inclusivo na rede pública do Distrito Federal, os quais trabalharam em salas inclusivas com alunos com deficiência intelectuais.

Foram identificados dois eixos importantes para a análise dos dados:

- Eixo A: As políticas de inclusão implementadas pela SEEDF e seu impacto na escola.

- Eixo B: O aluno com deficiência intelectual e as estratégias pedagógicas utilizadas pelos professores na educação inclusiva ao longo das últimas duas décadas.

\subsection{Eixo A: As políticas de inclusão implementadas pela SEEDF e o impacto das mesmas na escola}

O eixo A analisa trechos das entrevistas que evidenciam como ocorreu a inclusão de alunos com deficiência intelectual ao longo dos últimos vinte anos, aproximadamente, no Distrito Federal, e o impacto desta experiência nas dinâmicas educativas que envolviam os professores.

Será discutido o impacto das políticas públicas de inclusão na escola refletindo sobre pontos que se destacaram ao longo da análise dos dados de pesquisa, a saber: a resistência do professor com relação à implementação da política pública de inclusão; o medo proveniente da implementação de uma nova política pública educacional para o corpo docente; o modo como os professores foram apresentados à política de inclusão (cursos, reuniões, conversas de corredor etc.); o debate inicial sobre a inclusão nas escolas, a ausência de orientações gerais para direcionar o trabalho a ser realizado com os alunos incluídos (trabalho docente isolado); a transformação provocada pela inserção dos alunos incluídos no ambiente escolar; a disparidade temporal da implementação das políticas públicas; e a inclusão escolar como propulsora da busca dos professores por cursos de formação continuada.

Nesse contexto investigativo, as professoras foram convidadas a rememorar o período inicial da implementação das políticas públicas inclusivas e relataram, majoritariamente, a dificuldade em compreender como seria o trabalho docente e a resistência delas a esta implementação. Sobre isso, a professora Açucena narra: 
"Eu lembro sim (referindo-se ao início da inclusão) [...]. Eram muito afloradas as discussões sobre o assunto; uns queriam, outros não queriam. Porque o professor não estava preparado! Até hoje, eu acho que ainda não está preparado. Entrava o professor mais novo e pegava o menino porque a turma sobrou. Então, não era preparado para dar aula para um aluno incluído, nem era preparado para trabalhar com aluno que tem deficiência. Então, muitos alunos ficavam mesmo 'largadinhos', lá no final da sala, por muito tempo, até mudar essa mentalidade aí. O professor pensava muito só nele. Então, ele não pensava muito no aluno não [...]. Eles diziam que não sabiam trabalhar porque não tinham preparação[...]. Falavam que queriam impor esse aluno, e que ninguém tinha feito nada antes por esse aluno! E assim, a gente ficava com pé atrás, né? Não pensava muito em aceitar e ir atrás, estudar e tal... Acho que mais tarde foi acontecendo, assim, foi tendo curso, foi se falando mais. Aí, o professor aceitou melhor. Mas no começo não foi fácil não."

Pode-se observar no relato da professora Açucena que o processo inicial de implementação da política inclusiva foi recebido pelos docentes de modo impositivo. Não obstante, os professores criaram muita resistência em razão de não saberem lidar com as diferenças, com a novidade e, sobretudo, com os obstáculos em desenvolver uma pedagogia voltada para o ensino inclusivo.

A resistência em enfrentar turmas com alunos com deficiência intelectual se dava, segundo Glat e Nogueira (2003), devido ao professor trazer um entendimento de ensinoaprendizagem como uma metodologia universal, que se repetia em todas as épocas e sociedades. Dessa forma, entendia-se que existiam dois tipos de educação: a normal e a especial, sendo que a normal atendia a todas as pessoas em geral e a especial era para as pessoas com algum tipo de deficiência. Glat e Nogueira (2003) comentam que o professor tinha uma postura diferente em relação aos alunos:

Esta concepção de normalidade acabou por gerar dois tipos de processos de ensinoaprendizagem: o 'normal' e o 'especial'. No primeiro caso, o professor estaria frente aos alunos considerados 'normais', que seguem o padrão de aprendizagem para o qual ele foi preparado durante sua formação; no segundo caso, estariam os alunos que apresentam os denominados 'distúrbios ou dificuldades de aprendizagem' e/ou aqueles que precisam de processos de ensino-aprendizagem diferenciados por apresentarem deficiências ou demais necessidades educacionais especiais. (pp. 135-136)

Ainda nessa linha de pensamento, a professora Orquídea, quando narra a chegada dos alunos incluídos na escola, revela o medo que teve em desenvolver o trabalho docente nessas turmas. No início, as mudanças impostas pela inclusão foram determinantes para o desenvolvimento do seu ofício, considerando que a entrada de um público novo provocou um 
sentimento preconceituoso que fora ressignificado em seu comportamento mais adiante. Isso pode ser observado em sua fala:

"Para ser sincera, eu sempre tive medo do ensino especial, sempre! Eu caí de paraquedas no ensino especial. Fiquei sem voz, e por ter ficado sem voz, fui para educação precoce. Só que eu sempre tive medo de crianças especiais, de não dar conta, não sei porque. Hoje, eu vejo que eu era uma burra. Hoje eu fico 'gente, como é que eu tinha medo de crianças, de pessoas especiais?!' Mas antes eu tinha [...]."

O relato da professora Orquídea vai na mesma linha de Pletsch (2009) que assevera que, num primeiro momento, quando um professor se depara com o aluno com deficiência em sua sala de aula, há um sentimento de incapacidade e medo, podendo até mesmo afastar o professor e lhe causar estranheza. A falta de preparo não permite ao docente realizar um trabalho pedagógico adequado aos referidos alunos, como indicado em seu artigo:

Avaliamos que o despreparo e a falta de conhecimentos estão diretamente relacionados com a formação ou capacitação recebida. Além disso, podemos afirmar que existe um grande descrédito sobre a capacidade do aluno especial se desenvolver e agir de forma autônoma. ... Neste sentido, advertimos que, num primeiro momento, são comuns sentimentos de incapacidade e até mesmo de medo frente ao ingresso de um aluno com algum tipo de deficiência ou distúrbio de comportamento em sala de aula regular, podendo afastar o professor daquilo que não conhece e lhe suscitar estranheza. Em outras palavras, muitas vezes a falta de preparo e informação impede o professor de desenvolver uma prática pedagógica sensível às necessidades do aluno especial incluído. (Pletsch, 2009, p. 148)

Nessa mesma linha, a professora Rosa acredita que o início da inclusão foi difícil, conforme veremos a seguir:

"Quando eu cheguei aqui (referindo-se à chegada na SEEDF), foi em noventa e nove, tinha aquela separação; tinha as pessoas com deficiência auditivos, visuais, as pessoas com deficiência mentais, e tinha os alunos regulares [...]. Mas, mesmo assim, eu não lembro de ter tido essa preocupação com redução de turma, de ter um olhar diferente para aquela criança. Você podia optar pela turma inclusiva sem ter curso, sem preparação, sem nada. E eu não tinha nem conhecimento. [...]. Eu fiquei meio perdida [...]. Eram siglas novas, denominações novas. E, aí, falaram: "Não pega nenhuma turma de DM (as pessoas com deficiência intelectual) porque você vai ficar doida". Não tem acompanhamento, não tem nada para te ajudar, você vai se virar sozinha! Aí, eu fiquei com medo! E falavam: 'Os louquinhos!'. Esses ai são os louquinhos. E, aí, você vai ficar doida também!” 
Mais uma vez, incapacidade e estranheza caracterizam a sensação vivenciada no momento inicial da inclusão. Importante constatar, na fala da educadora, os motivos que geraram esses sentimentos de desconforto. Naquela época, as turmas inclusivas não tinham redução do número de alunos e não havia formação docente para realizar o trabalho pedagógico. Ocorria, portanto, uma negligência geral: ausência de turmas reduzidas e despreparo, pois era comum o professor assumir turmas inclusivas sem conhecimento mínimo sobre a temática (pedagogia especializada, materiais e recursos para desenvolver uma metodologia pertinente etc.). Sugere-se da fala da professora Rosa, por exemplo, que os professores, na época, não tinham uma orientação adequada para que pudessem conduzir seu trabalho pedagógico, acarretando uma prática docente solitária e sem o acompanhamento de profissionais especializados em inclusão escolar. Ela comenta: "Não tem acompanhamento, não tem nada para te ajudar, você vai se virar sozinha!"

Todo o panorama até aqui analisado revela que a inclusão no contexto escolar foi constituída sem oportunizar aos profissionais da escola, de maneira geral, um suporte teórico sobre o assunto. Dessa lacuna desdobraram-se não somente práticas pedagógicas inadequadas, mas também os discursos pouco fundamentados e perpassados por sentimentos já verificados nos dados aqui apresentados: medo, resistência, estranheza, incapacidade e preconceito.

Nesse contexto, a fala da professora Rosa mostra os termos pejorativos ligados à imagem do aluno com deficiência: “E falavam: 'os louquinhos!'. Esses, aí, são os louquinhos e, aí, você vai ficar doida também!." Verificamos que os professores não acreditavam no potencial de seus alunos, subjugando-os e menosprezando seu potencial de desenvolvimento. Neste sentido, Barbosa e Souza (2010) asseveram que:

As crenças que o professor tem sobre os alunos com necessidades especiais influenciam o seu modo de ensiná-los. Essas crenças são resultantes das representações que foram construídas ao longo da história sobre a criança com necessidades especiais que, muitas vezes, têm em sua base rótulos e estigmas. Assim, ao entrar na escola tanto esse sujeito como os professores terão que se defrontar com essas representações e enfrentar o desafio de superá-las. Em razão disso, as representações que o professor tem acerca deste aluno definirá a forma de relação entre eles e, em consequência, as possibilidades de desenvolvimento do aluno. (p. 353)

As reflexões acerca desta questão revelam que o desconhecimento das políticas inclusivas, aliado ao despreparo na formação docente, reflete um trabalho pedagógico improdutivo promovendo as diferenças e descrença nas potencialidades dos seus educandos com deficiência. A respeito dessa temática, Pimentel (2012) explica: 
A ausência de conhecimento do professor sobre as peculiaridades das deficiências, o não reconhecimento das potencialidades destes estudantes e a não flexibilização do currículo podem ser considerados fatores determinantes para barreiras atitudinais, práticas pedagógicas distanciadas das necessidades reais dos educandos e resistência com relação a inclusão. (p.139)

Similarmente às considerações da professora Rosa, Orquídea relata as diferentes experiências por que passou quando começaram os debates sobre inclusão nas escolas públicas que lecionou. Ela narra que ter um aluno com deficiência em sua classe parecia uma realidade muito distante e que havia obstáculos provenientes de uma suposta incapacidade do grupo de alunos no que tange ao desenvolvimento intelectual. Orquídea narra:

"Na verdade, eu não tinha tido experiência, a gente ouvia falar (referindo-se à inclusão). Mas como se fosse uma realidade mais distante. E, quando falava de inclusão, eu não tinha essa ideia de que se tratava de uma pessoa com a capacidade mental muito comprometida. Normalmente, o que vinha na cabeça seria um cadeirante, uma pessoa com um comprometimento físico e não intelectual. Aí, indo para as séries iniciais, educação infantil, é que a gente vai vendo essa outra realidade em que esses alunos estão."

Novamente, na narrativa da professora Orquídea, podemos observar que o desconhecimento sobre a inclusão tornava possível uma impressão errônea sobre as necessidades educativas do alunado, assim como um despreparo no fazer pedagógico dirigido a cada tipo de especificidade. Desta linha de pensamento decorre que o professor acaba culpabilizando seus alunos por sua deficiência, acarretando a produção de atitudes discriminatórias e uma educação individualizada, mais voltada para as incapacidades dos alunos do que para a prática de uma pedagogia promotora desigualdade.

Para a professora Violeta, o debate nem sequer ocorria. Apenas tiraram os alunos dos centros de ensino especial e os colocaram em classes inclusivas dentro das escolas regulares, sem muita explicação, conforme ela relata:

"Quando eu entrei na Secretaria, eu ouvia sobre a inclusão. Nessa época, não existia inclusão... existia assim, mais ou menos. Das classes especiais tiraram as crianças da segregação, lá do centro (referindo-se aos alunos com deficiência). Pelo menos a proposta de inclusão escolar levou esses alunos para a escola. Mas, de qualquer forma, eles ainda ficavam lá na classe segregados."

A partir do relato da professora Violeta, pode-se perceber que a inclusão incialmente foi implementada como uma espécie de remanejamento geográfico: da classe especial para a classe inclusiva. Problematiza-se, nesse ínterim, o cuidado pedagógico necessário para retirar os 
alunos com deficiência da condição de segregação anteriormente vivida, assim como a efetiva migração desses alunos para o novo modelo educacional (Silva, 2014). Nesse sentido, a afirmação da professora Violeta corrobora a pesquisa feita por Pletsch (2014a), na qual denuncia que, no início da inclusão, a maioria dos alunos com deficiência matriculados se concentraram em escolas e classes especiais, sendo que poucos foram para as escolas regulares.

Os alunos com deficiência, portanto, continuavam a ter uma educação segregada, fora das classes comuns, diferente do que previa a nova legislação. A pesquisa da autora revela que:

No caso da deficiência intelectual, em 2001, totalizavam 212.996 matrículas. A maioria dos matriculados se concentrou em escolas e classes especiais (89\%) e somente $11 \%$ em escolas regulares. (Pletsch, 2014a, p. 13)

É essencial, nessa linha de pensamento, entender a questão da inclusão como incontornável e parte do trabalho docente, ao constatar, como diz Padilha (2015), que a segregação é perniciosa e intolerável, embora essa percepção não baste para garantir a igualdade. A autora reforça que o processo de exclusão está imbricado à questão da desigualdade social, pois não há como separar aspectos políticos dos sociais e educacionais. Ao mesmo tempo, a pesquisadora ressalta que a inclusão deve ir além da simples legislação e tornar os alunos sujeitos do conhecimento historicamente acumulado pelo gênero humano.

Corroborando os relatos das professoras citadas, Tulipa lembra que houve muita negatividade por parte da comunidade escolar, principalmente em relação aos professores, sobre a implementação da política pública de inclusão na sua escola. Ela conta:

"Olha, eu lembro de algumas coisas (referindo-se ao início da inclusão), de algumas partes... Houve muitos comentários dos professores, como: Eu não acho que vá funcionar!; Eu não queria receber os alunos dessa forma, pois a escola não tem estrutura!"

Analisando a narrativa da docente, podemos observar que a recusa, por parte dos professores, desenhava pilares de que a inclusão estava fadada ao fracasso, pois havia uma descrença na funcionalidade, decorrente de uma imaturidade quanto aos conhecimentos das legislações sobre as políticas públicas de inclusão, assim como pela falta de informações sobre o aluno com deficiência, conforme discutimos anteriormente.

Além destas resistências, a professora Gardênia narra que o trabalho docente era solitário, como podemos perceber no seu relato: "Naquela época (referindo-se ao início da inclusão), a gente tinha um trabalho muito solitário”. Percebemos que, apesar de a professora ter tido informações iniciais sobre o trabalho docente no início da inclusão, que a orientaram e permitiram mudar sua postura com relação a seus alunos, seu trabalho na escola ainda 
continuava solitário, pois nem todos os outros professores tiveram uma formação inicial adequada para acompanhar o início do processo inclusivo.

Este relato vai na mesma direção da fala da professora Açucena, revelando que, no início da implementação da inclusão, o trabalho era solitário, como podemos verificar em seu relato:

"Era o professor dentro da sala de aula que tinha que dar conta. O professor trabalhava meio que sozinho, meio isolado. Quem dava sorte de arranjar uma escola boa, com profissional bom, bom diretor, coordenador, tudo bem. Mas quem não dava sorte...!"

A professora Açucena compartilha com a professora Gardênia a solidão:um trabalho docente sem o apoio de uma equipe multidisciplinar para direcionar o pedagógico.

Na questão preconizada pelo MEC (2008), a escola também deveria ter estrutura adequada para receber os alunos com deficiência, pois a garantia à acessibilidade e às condições estruturais e pedagógicas são direitos que as pessoas com deficiência adquiriram depois de muitas lutas.

Neste sentido, a professora Tulipa narra:

"Então, sempre eu ouvia a mesma frase: A escola não tem estrutura para receber os alunos com necessidades especiais! A escola não tem estrutura para receber aluno! [...]. Mas tem que receber!"

Analisando o relato da professora Tulipa, concluímos que a inclusão encontra um desafio maior no fator humano do que propriamente no estrutural. Porém o fator físico das escolas do DF foi justificativa produzida por alguns professores para a impossibilidade de uma escola inclusiva.

Parece que quando a inclusão foi implementada, a escola não tinha realmente uma estrutura física adequada para receber os alunos com deficiência. Contudo, consta no artigo de Bareta e Viana (2014) que:

O sistema escolar tem que se adaptar-se às necessidades dos alunos. Para uma escola ser inclusiva de fato não basta apenas receber os alunos, deve-se antes de qualquer coisa fazer um levantamento das adaptações que devem ser feitas na escola para receber os mais variados alunos. Pensar na adequação de portas para passagem de cadeira de rodas, rampas de acesso, adaptação de banheiros e bebedores, conserto de pisos irregulares, retirada de obstáculos do caminho, mesas adequadas, refeitório, etc. Além de eliminar as barreiras arquitetônicas, é importante adotar métodos e práticas de ensino adequado 
às diferenças dos alunos. Sem esquecer os materiais e equipamentos que atendam a diversidade e facilitem a aprendizagem. (pp. 120-121)

Nesta concepção, a professora Violeta narra que houve muita resistência também dos professores, em relação às condições físicas da escola.

"A questão da estrutura física, os professores reclamavam muito de não ter recursos para trabalhar com esse aluno. Aí, a resistência maior era dos professores. [...]. Àquela época, os professores não aceitavam muito. A escola também não tinha muita infraestrutura, como ainda hoje não tem. Não é o ideal, mas melhorou, daquele tempo para cá a questão da aceitação dos professores, da estrutura, da adaptação do ambiente. Melhorou bastante!"

Novamente, pode-se perceber que a resistência dos professores à implementação da inclusão também passa pela estrutura física. Nos ambientes educativos, a inclusão é um fator considerado para que os alunos aprendam a valorizar a diferença pela convivência, solidariamente e participativamente (Bareta \& Viana, 2014). A valorização do espaço escolar constitui um ponto crucial para o desenvolvimento das ações pedagógicas (Silveira, 2012).

A questão de falta de estrutura escolar é condicionante no entrave à expansão da educação inclusiva, como podemos observar nas falas das professoras. Falta de materiais, problemas de adaptação do ambiente escolar, falta de recursos financeiros, limites de recursos didáticos, barreiras organizacionais e falha na formação acadêmica e profissional dos docentes são obstáculos para a efetivação das políticas públicas educacionais inclusivas, ocasionando o isolamento do aluno com deficiência e dificultando a sua motivação para o seu desenvolvimento (Silveira et al., 2012).

Além da falta de estrutura física na escola, que impossibilita o bom trabalho docente, a mudança no cotidiano da escola regular, diante da chegada do aluno a ser incluído em salas de turmas regulares, apresenta-se como um fator a ser considerado na análise desta pesquisa.

Desta forma, observamos, na fala da professora Orquídea, que, no início do processo de inclusão, a chegada do aluno com deficiência provocou estranhamento por parte da comunidade escolar.

"Afetou (referindo-se à chegada do aluno com deficiência na escola). Eu acredito que foi um choque para a escola. Porque as escolas tinham uma cultura, um pensamento, que: Se é um aluno especial, deveria ir para o Centro de Ensino Especial. Então, eu acredito que foi um choque para a escola porque não estava preparada. Os profissionais não estavam preparados e os alunos da escola também não. "

Neste sentido, a professora Tulipa relembra: 
"Mudou meu cotidiano (referindo-se à chegada da inclusão na escola). Aqui, eu só via alunos ditos normais. Aí, de repente, eu tinha que receber (referindo-se aos alunos com deficiência), tomar o maior cuidado... porque aqui era um ambiente diferenciado da sala de aula. Então, para ele não esbarrar, não se machucar [...]. ",

É notório na fala da professora Tulipa, assim como na fala da professora Orquídea, que a chegada dos alunos com deficiência mudou completamente o cotidiano da escola e o comportamento profissional e pessoal das docentes entrevistadas.

Podemos notar, segundo Silveira (2012), que o desenvolvimento profissional na escola vai em direção às mudanças ocorridas com o professor, que é um dos principais protagonistas das transformações em uma instituição educacional, visto que o seu desenvolvimento impacta o desenvolvimento dos seus alunos. Desta forma, a autora assegura que:

Essas mudanças podem ser consideradas como aprendizados e desenvolvimento profissional, pois para alguns profissionais da escola, houve uma tomada de consciência que incorporou à sua formação como elemento constitutivo da prática profissional a partir de reflexões fundamentadas e compartilhadas com o grupo da pesquisa e da escola. (p. 24)

$\mathrm{Na}$ mesma linha, a professora Violeta comenta que as mudanças ocorridas na escola com a chegada do aluno com deficiência passaram a constar no projeto político pedagógico da escola, como se percebe na sua narrativa:

"Começou a se pensar (referindo-se à inclusão) mais no projeto político e pedagógico. $O$ projeto político e pedagógico é o que norteia o trabalho da escola. Começou a se pensar mais na inclusão desses alunos no espaço, no projeto em si; no espaço da escola, nas atividades. Algumas atividades têm que ser adaptadas pensando que existem esses alunos. Eu acho que a escola, em relação à organização, começou a mudar um pouco porque começou a pensar mais na escola como um todo também, visando atender esses alunos no projeto político e pedagógico."

A professora acredita que a chegada do aluno incluído na escola regular possibilitou mudanças estruturais no projeto político pedagógico. Como se vê no depoimento da professora Violeta, é de suma importância o papel do projeto político pedagógico no direcionamento do atendimento ao educando com deficiência, pois é por meio dele que se torna possível a inserção desse educando em todas as atividades escolares comuns.

Além das questões apontadas até aqui, observamos que ocorreu uma disparidade temporal entre as professoras pesquisadas acerca da implementação das políticas públicas 
inclusivas. Para a professora Açucena, os primeiros momentos da inclusão nas escolas públicas do DF ocorreram entre 1991 e 1992, como ela relata na sua fala.

"Foi logo nos primeiros momentos (referindo-se à chegada da inclusão nas escolas). Talvez acho que uns 90, deixa eu ver, entre 91 e 92 mais ou menos."

Já para a professora Tulipa, o início da inclusão se deu por volta de 1994, como podemos observar em sua narrativa.

“Eu vim a ter contato (referindo-se à inclusão) a partir de 94. Por ter vindo trabalhar na escola normal. Aí, começou o discurso, da questão do olhar diferenciado. Mas quando a gente depara, só agora, alguns anos bem depois, é que a gente vai ter a escola inclusiva."

Para a professora Rosa, o início da inclusão ocorreu por volta de 2005, como ela relata.

"Sobre a inclusão, demorou. Sobre a inclusão, eu acho que foi em 2005, mais ou menos por aí. [...]. Quando começou a inclusão não foi nem o debate, mas o questionamento: Como vai ter inclusão? As turmas não tinham redução, só chegava lá e 'vai ser incluído menino!' Incluir para a gente era, não era nem o nome inclusão da sala, era integração. Integrava o menino lá dentro. Ele que tinha que se integrar ao grupo; não era o grupo que tinha que se adaptar a ele. Então, foi uma crueldade. Você chega sozinho com o seu problema e tem que se encaixar ali, não os outros que tem que se encaixar a você, compreender você, conhecer você."

Podemos perceber nos relatos das professoras entrevistadas que houve uma dissonância em relação ao início da implementação das políticas de inclusão nas escolas; observamos que houve um espaçamento de anos para que as docentes começassem a ouvir falar sobre a implementação do sistema inclusivo nas escolas em que trabalhavam. Esta disparidade de datas para cada professora pode ter decorrido da implementação de uma política inclusiva sem planejamento de gestão.

Observamos, na narrativa da professora Violeta, que a inclusão teve início bem mais tarde, por volta de 2009:

"Demorou bastante! (referindo-se à demora do debate nas escolas). Eu vi o negócio aumentar mesmo foi de 2009 para cá.” 
Na narrativa da docente está claro que a inclusão chegou após a implementação das políticas de governo ${ }^{12}$ orientadas pela Política Nacional de Educação Especial, durante o governo do presidente Luís Inácio Lula da Silva (2003-2010) (Garcia \& Michels, 2011).

Os depoimentos acima citados trazem luz à questão de como o percurso da implementação da inclusão nas escolas públicas do Distrito Federal foi acidentado, o que dialoga diretamente com a própria história da educação das pessoas com deficiência no Brasil. A percepção dos professores acerca do início da inclusão pode demonstrar uma não homogeneidade no processo inclusivo nessas escolas, o que reflete a falta de preparação da gestão pública em aplicar corretamente as políticas educacionais e preparar os atores do processo para atuarem com essa clientela.

Outro aspecto identificado nas análises dos dados foi a importância da inclusão escolar na busca dos professores por cursos de formação continuada.

A professora Gardênia recorda que teve conhecimento sobre o debate da inclusão por meio de cursos. Ela rememora:

"Olha, eu lembro (referindo-se ao início da inclusão). Foi um curso da UnB, que inclusive eu guardo o material até hoje com muito carinho... Realmente, a gente fez um ajuste das nomenclaturas. Porque ainda tinha gente usando DM (deficiente mental), é DI (deficiente intelectual), outros já usavam DI. Então, a gente começou a aprender sobre essas coisas todas [...]. Na escola, a gente ainda tinha que defender esses meninos. "

Refletindo sobre a fala da professora Gardênia depreende-se que seu olhar sobre a inclusão foi alterado depois da formação que teve na UnB. Isso mostra que os professores que não tiveram informações adequadas sobre a implementação da política pública de inclusão, com administração de cursos, apresentaram resistência por não conhecerem o assunto.

Podemos notar, também, que a formação em prol do processo inclusivo faz com que o professor tenha um maior cuidado com seu aluno com deficiência, como podemos notar em sua fala: "Na escola a gente ainda tinha que defender esses meninos".

A professora Rosa vai na mesma linha da professora Gardênia. Para ela, no início das discussões sobre inclusão, houve cursos para ampliar os conhecimentos dos professores, porém os cursos não eram muito divulgados.

\footnotetext{
${ }^{12}$ As políticas de governo implementadas pela Política Nacional de Educação Especial foram: a) Programa de Implementação de Sala de Recursos Multifuncionais; b) Programa Educação Inclusiva: direito a diversidade; c) Programa Incluir.
} 
"A gente começou a participar de encontros nos centros de ensino (referindo-se aos cursos que a SEEDF promoveu sobre inclusão). Os cursos tiveram início por volta de 2003. A gente começou a fazer esses cursos, onde ensinava como é elaborar material. Antes, eu achava que os materiais eram iguais aos dos meninos do regular [...] A gente ficava sabendo dos cursos por boca: 'Olha, vai ter um encontro lá no centro de ensino com os professores para dar palestra ou para ensinar alguma coisa,",.

Pelo depoimento da professora Rosa, percebe-se que a fundamentação teórica e prática é essencial para fomentar uma inclusão adequada, por meio da conscientização dos profissionais ligados direta ou indiretamente ao educando. De acordo com Pimentel (2012), o professor deve ter subsídios teóricos e metodológicos para embasar sua ação pedagógica na escola inclusiva; só assim ele terá possibilidade de buscar novas formas de ensino para tornar possível o aprendizado de todos os seus alunos. Portanto, o professor deve ter clareza epistemológica que fundamente o conhecimento de modo a promover o processo de aprendizagem por meio da percepção das especificidades do educando. Pois, segundo o autor,

A ação pedagógica numa escola inclusiva irá requerer que o professor tenha subsídios teóricos e metodológicos para buscar novas formas de ensinar de modo que seja possível o aprendizado de todos. (Pimentel, 2012, p. 145)

Os cursos para esclarecimentos sobre a implementação das políticas públicas de inclusão que estavam sendo implantadas na SEEDF ocorreram, como relata a professora Rosa, por volta de 2003. De acordo com o MEC (2008):

Em 2003, é implementado pelo MEC o Programa Educação Inclusiva: direito à diversidade, com vistas a apoiar a transformação dos sistemas de ensino em sistemas educacionais inclusivos, promovendo um amplo processo de formação de gestores e educadores nos municípios brasileiros para a garantia do direito de acesso de todos à escolarização, à oferta do atendimento educacional especializado e à garantia da acessibilidade. (p. 11)

Podemos perceber, diante dos relatos das professoras pesquisadas, quanto foi falha a formação na graduação no que tange ao debate da inclusão. Isso se explica por serem professores que tiveram uma formação acadêmica antes de entrar em vigor a política de inclusão no sistema de ensino. Pletsch (2014) afirma que é necessário que se tenham, na formação inicial do professor e na formação continuada, fundamentos teóricos articulados com as práticas para que ocorra um processo de ensino-aprendizagem criativo e significativo para os alunos com deficiência ou não.

Tulipa comenta sobre a necessidade da formação continuada: 
"Olha, muita necessidade (referindo-se à necessidade de fazer cursos). Já até me inscrevi em libras e outros cursos, mas eles sempre deram prioridade para quem está trabalhando na área."

Percebemos que, pelo relato da docente, os cursos para formação continuada na área de educação inclusiva foram e são oferecidos.

A professora Violeta também compartilha a opinião da professora Tulipa, pois acredita que a Secretaria de Educação oferece cursos, porém é muito difícil conseguir uma vaga, pois são direcionadas para os professores que trabalham na área de educação especial, deixando os outros impossibilitados de realizar os treinamentos.

“A barreira maior era com os professores. Eu acho, que pela falta de preparo. Hoje em dia, tem muitos cursos, EAPE (Escola de Aperfeiçoamento dos Profissionais de Educação) oferece muitos cursos. Mas naquela época (referindo-se ao início da inclusão), tinham poucos cursos. Quem fazia curso na área de ensino especial era quem trabalhava com ensino especial. E aí não tinha muita oportunidade para o professor que trabalhava com inclusão."

Podemos perceber, pelo relato da professora, que os cursos eram oferecidos pela SEEDF, porém existiam poucas vagas. Nesse sentido, Pimentel (2012) afirma que o sistema educacional deve promover cursos de formação docente, visto que existem nas escolas alunos com necessidades educativas especiais devidamente matriculados. No entanto, faz-se necessário, também, que se promovam vagas e critérios mais abrangentes para englobar todos os professores que estejam interessados em realizar os cursos, e não só para os que já trabalham com a educação especial. Dessa forma, professores que ainda não trabalham com alunos incluídos podem estar preparados para o trabalho docentes com tais sujeitos. De acordo com Pimentel (2012):

A inclusão educacional requer professores preparados para atuar na diversidade, compreendendo as diferenças e valorizando as potencialidades da cada estudante de modo que o ensino favoreça a aprendizagem de todos. A inexistência desta formação gera um fenômeno da pseudoinclusão, ou seja, apenas da figuração do estudante com deficiência na escola regular, sem que o mesmo esteja devidamente incluído no processo de aprender. Estar matriculado e frequentando a classe regular não significa estar envolvido no processo de aprendizagem daquele grupo. (p. 140)

Neste contexto, a professora Orquídea acredita que os cursos que fez a ajudaram muito, como se percebe na sua narrativa. Porém, para ela, os cursos de pós-graduação ainda são fracos e sem práticas da educação inclusiva. Ela narra: 
"Nossa! Ajuda muito (referindo-se à importância dos cursos)! Só que eu analiso hoje em relação às pós-graduações, que são cursos muito vazios. Alguns são cursos que têm poucas informações. Algumas pós-graduações têm falta de informações. As pós-graduações estão com cursos um dia no mês. Então, eu acho pouco! O que eu observo em relação aos cursos menores, eles são ministrados em uma quantidade maior de dias, porém com uma carga horária menor em relação à pós-graduação, só que tem uma qualidade um pouco maior de vivência. Ano passado mesmo, eu fiz um curso que foi a noite, que era de educação precoce. Então, te ensinava na prática muita coisa. Eu achei bem mais vantajoso!”

Diante da narrativa da professora Orquídea, podemos perceber a importância dos cursos com ênfase na prática pedagógica. Essa reflexão de Orquídea comunga com as observações de Pletsch (2009), quando faz uma reflexão acerca dos cursos. A autora diz que o desafio atual nos cursos de formação para professores é a produção de conhecimentos necessários para que o professor compreenda determinadas práticas educacionais no intuito de desenvolver o processo de ensino-aprendizagem voltado para a diversidade. Com isso, é necessário que as políticas públicas inclusivas façam uma adequação na formação docente, com habilidades e competências que venham a atender adequadamente às exigências do ensino inclusivo. Desta forma, a autora afirma que:

O atual e grande desafio posto para os cursos de formação de professores é o de produzir conhecimentos que possam desencadear novas atitudes que permitam a compreensão de situações complexas de ensino, para que os professores possam desempenhar de maneira responsável e satisfatória seu papel de ensinar e aprender para a diversidade. Para tanto, faz-se necessário elaborar políticas públicas educacionais às novas exigências educacionais e definir um perfil profissional do professor, ou seja, habilidades e competências necessárias aos professores de acordo com a realidade brasileira. (p. 148)

Porém, para a professora Açucena, os cursos eram precários ou quase inexistentes. Como consta no seu relato:

"Nessa época (referindo-se ao início da inclusão), não tinha nada (referindo-se à ausência de cursos)! Os alunos eram meio que jogados na sala. A gente conhecia muito pouco. Se o professor quisesse ficar mais por dentro, ele tinha que ir atrás de cursos. No caso, eu ia atrás! Na primeira turma, eu lembro que tinha uma professora itinerante, ela ia na escola e dava umas orientações para mim, falava algumas coisas."

Nessa linha de pensamento, pode-se observar que, no início da inclusão, os cursos de formação inicial e continuada eram bem deficitários no DF. Atualmente, alguns cursos ainda não estão bem planejados para formar os professores para atuarem na educação inclusiva. 
Diante disso, Pletsch (2009) assegura que a formação de professores ainda não consegue suprir as reivindicações da educação inclusiva. Poucos são os cursos que oferecem disciplinas e conteúdos voltados para educação de pessoas com deficiência. A autora ressalta que:

No Brasil, a formação de professores e demais agentes educacionais ligados à educação segue ainda um modelo tradicional, inadequado para suprir as reivindicações em favor da educação inclusiva. Vale destacar que, dentre os cursos de Pedagogia e Pedagogia com habilitação em Educação Especial, poucos são aqueles que oferecem disciplinas ou conteúdos voltados para a educação de pessoas com necessidades especiais. ... O fato é que, de maneira geral, as licenciaturas não estão preparadas para desempenhar a função de formar professores que saibam lidar com a heterogeneidade posta pela inclusão. (p. 150)

A professora Violeta vai na mesma direção da professora Açucena, pois narra que, no início do discurso sobre inclusão, ela teve que buscar cursos por conta própria e se especializar no assunto.

"Na época (referindo-se ao início da inclusão) foi de cara (repentino)! Aí, eu comecei a participar mais dessas questões de palestra, curso, workshop [...] Estava na época da propulsão da inclusão."

Por isso, é tão importante que o professor tenha acesso aos cursos de formação continuada para que sua ação pedagógica esteja em consonância com práticas não engessadas e desgastadas. De acordo com Jesus e Effgen (2012), a formação continuada dos docentes é uma possibilidade de pensar sobre o processo de ensino-aprendizagem das especificidades escolares e também nos processos de escolarização dos alunos da educação inclusiva. Estes cursos devem conter diferentes situações que fazem parte do ato educativo, assim como as análises docentes e os espaços para reflexão coletiva, para com isso pensar soluções para um bom desempenho educacional.

A professora Gardênia acredita que os cursos contribuíram para mudanças de atitudes na prática educacional.

“Olha, ajudaram muito, viu (referindo-se aos cursos do início da inclusão)?! Principalmente, na questão de apurar melhor esse olhar; saber para quem pedir ajuda. Porque, poxa vida! Você chega na escola e não tem quem te informe. Ai, você tem que buscar fora."

Corroborando com a narrativa da docente, Pimentel (2012) discute que os cursos de formação podem subsidiar o fazer pedagógico, assim como a avaliação da ação e a investigação sobre o ensino-aprendizagem, promovendo, com isso, um novo olhar e um novo modo de agir. Dessa forma é possível promover mudanças na qualidade das aulas, tornando possível que os 
professores atuem de forma adequada diante do seu aluno com deficiência. De acordo com o autor

Isto requer investimento constante em práticas investigativas, problematizando o que acontece no cotidiano da sala de aula e buscando referenciais teóricos e epistemológicos que favoreçam a compreensão da aprendizagem. (Pimentel, 2012, p. 145)

Neste ínterim, a escola é também um local de formação, por possibilitar as transformações de práticas pedagógicas e contribuir para o professor investigar como está o ensino e a aprendizagem dos seus educandos. A formação continuada é o momento em que o professor pode repensar sua ação educativa e potencializar sua prática pedagógica (Jesus \& Effgen, 2012).

Não é possível realizar educação inclusiva de qualidade sem ampliar os recursos, sem melhorar as condições de ensino e aprendizagem e sem valorizar os professores. Assim, acontece uma pseudoinclusão, que é mais perversa do que a segregação, promovendo um sentimento de incapacidade e de não pertencimento ao educando (Pimentel, 2012).

No próximo eixo será analisado como as professoras pesquisadas utilizavam as estratégias pedagógicas no ensino inclusivo de alunos com deficiência intelectual, assim como suas opiniões em relação a todo o processo de inclusão ao longo destes vinte anos, aproximadamente, de implementação.

\subsection{Eixo B: $O$ aluno com deficiência intelectual e as estratégias pedagógicas utilizadas pelos professores na educação inclusiva ao longo das últimas duas décadas}

$\mathrm{O}$ eixo $\mathrm{B}$ analisa trechos das entrevistas que demonstram como as professoras entrevistadas utilizavam estratégias pedagógicas na educação inclusiva de alunos com deficiência intelectual, assim como suas opiniões em relação a todo o processo de inclusão ao longo destes vinte anos, aproximadamente, de implementação.

Será discutido o impacto das políticas públicas de inclusão nas práticas pedagógicas utilizadas pelas professoras no ensino de alunos com deficiência intelectual voltadas para o desenvolvimento de tais alunos. Também será analisado como as professoras opinam em relação à inclusão no decorrer dessas duas décadas de implementação, quanto ao sucesso e o insucesso desta política pública de inclusão.

Várias estratégias foram relatadas pelas professoras acerca do trabalho desenvolvido com o aluno com deficiência intelectual na educação inclusiva. Algumas docentes revelaram 
estratégias parecidas, pois elas utilizam materiais concretos e forma lúdica de aprendizado para obter bons resultados pedagógicos. Verificamos esta questão no relato da professora Orquídea:

"Utilizo o material concreto, lúdico. Tudo que chame a atenção ou que prenda a atenção do aluno com deficiência intelectual (referindo-se à estratégia pedagógica que utilizava na classe inclusiva). Quando ele cansa um pouco daquele material, eu troco o material e passamos para outro. É importante que o material utilizado esteja sempre prendendo a atenção do aluno. Também é necessário que seja uma atividade prazerosa. Eu observo se o aluno se sente motivado. Mesmo com déficit de aprendizado, ou com a sua dificuldade, ele vai tentando, se esforçando mais para conseguir. Eu acho que, para que o professor possa trabalhar adequadamente com o aluno, é importante a formação docente com cursos e também a boa vontade do professor."

Orquídea revela usar vários procedimentos pedagógicos. Ela utiliza material concreto e também a ludicidade, alternando estratégias sempre que necessário.

Para Silva e Arruda (2014), o material empregado e as estratégias pedagógicas desenvolvidas devem ser repensados pelo professor, afim de não ficar preso às mesmas atividades e materiais, de forma a atender às necessidades de seu aluno. Outro ponto é não ficar preso ao espaço delimitado da sala de aula, usufruindo dos vários ambientes pedagógicos da escola. Para que isso ocorra é necessário um bom e cuidadoso planejamento do professor, conforme indicado por Silva e Tavares (2009):

Toda atividade realizada no ambiente escolar tem seu foco intencional que se realiza na execução do planejamento de ensino, na organização das condições para que a aprendizagem ocorra efetivamente e que exige clareza quanto aos objetivos que se quer alcançar, e que também refere-se à estipulação da sequência de atividades e especificação dos reforçadores que serão utilizados, assim como a promoção de um ambiente facilitador da aprendizagem que estimule e aproveite as potencialidades diversas das crianças. (p. 72)

Outra observação feita a partir do relato da professora Orquídea, foi a importância de o aluno se sentir motivado pela atividade que a professora está aplicando naquele momento. $\mathrm{O}$ trabalho do professor deve estar aberto e diversificado, para que motive o aprendizado do aluno com deficiência intelectual. Também se faz importante flexibilizar uma abordagem em vários níveis de compreensão, entendimento e apropriação no desempenho das atividades, elogiando e incentivando a produção de aspectos positivos, num trabalho gradual sem cobranças e limitações (Silva \& Tavares, 2009), oportunizando o que Vigotski denominou "rotas alternativas" de aprendizagem. Sobre essa questão e ancorados na teoria de Vigotski, Martins, Tacca e Kelman (2009) afirmam que: 
A compensação é a capacidade que tem o organismo de, diante de uma função afetada, acumular uma energia psíquica capaz de tomar uma rota alternativa para que o desenvolvimento se complete (Vigotski, 1997). Este processo se desenvolve na medida em que a deficiência provoca um sentimento de menos valia que desencadeia uma força motriz que leva o indivíduo a reagir ao "defeito", estimulando o desenvolvimento de fenômenos psíquicos para sua superação. Juntamente com o defeito o organismo possui forças capazes de amenizá-lo. Assim o desenvolvimento não ocorre na linha do "defeito", pelo contrário, ele segue a direção oposta em razão da tensão criada pelas condições do defeito e da força reagente que leva o sujeito a agir criativamente no sentido de encontrar caminhos de rodeio e alcançar o desenvolvimento. (p. 2907)

Caldas e Souza (2014) propõem uma alternativa no que tange ao aproveitamento dos pares mais hábeis em sala de aula, e esse auxílio recíproco entre uma criança com dificuldade e outra mais apta para encontrem o nível real de aprendizagem e a zona do desenvolvimento proximal, com o objetivo de potencializar a aprendizagem e desenvolvimento de cada criança.

Outro aspecto observado na narrativa da professora Orquídea foi a valorização dos cursos de formação para o bom trabalho com o aluno com deficiência intelectual na sala inclusiva, no intuito do docente trabalhar atendendo às especificidades deste aluno para promover um ensino-aprendizado que atenda as expectativas de desenvolvimento desta criança, como já foi discutido no eixo A.

Similarmente à professora Orquídea, a professora Violeta utilizava estratégias pedagógicas com materiais concretos, e com formas lúdicas, como podemos verificar na sua narrativa.

"Com esses meninos (referindo-se ao aluno com deficiência intelectual), o ensino tem que ser mais lúdico. Não pode ser aquele ensino maçante [...]. Para eles tem que ser mais lúdico, todo o aprendizado. $O$ conceito que você for passar, tem que o usar o concreto para que eles assimilem melhor e façam associação."

Desta forma, entendemos que para produzir uma prática pedagógica que garanta um processo de aprendizagem significativo, é necessária uma atenção por parte do docente sobre a prática, compreendendo que ensinar é muito mais que transmitir conhecimento. O professor deve estar atento ao fato de que o desenvolvimento de uma criança com deficiência intelectual vincula-se às condições objetivas da aprendizagem. Nesta linha de pensamento, nos voltamos para os estudos de Vigotski (1934-2012) sobre defectologia, já abordados no capítulo 2 desta pesquisa. $\mathrm{O}$ autor argumenta que o desenvolvimento da criança com deficiência segue a mesma lei geral da criança considerada normal, mas percorre caminhos diferenciados. Assim, é importante que o professor conheça esses caminhos distintos para promover uma mediação 
pedagógica de" menos defeito em mais compensação" (Vigotski, 1934-2012, p. 17, tradução nossa).

Contudo, a professora Violeta narra que a criança com deficiência intelectual aprende de forma mais lenta.

"É lento o resultado (referindo-se ao aprendizado do aluno com deficiência intelectual), mas consegue. Às vezes, você quer que a criança aprenda a escrever o nome todo no final do semestre. No entanto, às vezes, ela aprende a escrever só o pré nome, e temos que compreender esses avanços. [...]. Foi o que ela conseguiu. De uma forma mais lenta, mas acontece o aprendizado. Muitas vezes, elas não atingem seus objetivos no planejamento, mas acontece."

Sobre essas situações, Silva e Arruda (2014) discorrem que o professor tem que saber trabalhar com a criança inclusa de forma a respeitar a diversidade e seu ritmo. Para isso é necessário um bom planejamento, que atenda as especificidades do aluno, para que não haja frustração com seu desempenho. As autoras afirmam que

Talvez, o significado da palavra - 'incluir' não esteja ligado a inserir pessoas diferentes na sociedade e sim fazer um trabalho diferenciado com essas pessoas, um trabalho que possibilite a autonomia, porque o professor deve estar em constante aprendizagem, buscando informações e estar sempre disposto a ouvir o aluno para um melhor desempenho do seu trabalho. Ao desenvolver seu planejamento, o professor tem que pensar no que ele está preparando e para quem ele está preparando, para que depois não venha a se frustrar, então terá que repensar sobre seu planejamento e aplicar um olhar diferente sobre o seu trabalho. É de grande importância, também, que o professor divida com outros profissionais da educação os seus avanços e retrocessos, nem todos os profissionais sabem de tudo. (p. 4)

Neste ínterim, observamos no relato da professora Tulipa uma estratégia pedagógica diferenciada e planejada com os outros professores da escola:

"No começo (referindo-se ao início da inclusão), eu pensava em fazer uma separação dos alunos com deficiência e dos alunos que não tem deficiência. Depois, eu resolvi que não iria fazer isso. Eu trabalhava do mesmo jeito que eu trabalho com os outros alunos. Eles(referindose ao aluno com deficiência intelectual) vão para o computador. Utilizo muitos jogos e alguns programas no software voltado para trabalhar a coordenação motora fina. De acordo com o planejamento de sala de aula do professor regente, eu desenvolvo a atividade aqui na sala de informática."

A professora Tulipa faz um trabalho diferenciado com os alunos com deficiência, pois ela é professora da sala de informática. Porém, inicialmente acreditava que deveria trabalhar 
com essas crianças de forma distinta. Contudo, ao longo do tempo, ela verificou que poderia aplicar as mesmas atividades dadas aos outros alunos. Modificou sua maneira de proceder pedagogicamente. Ela pensou que, no começo, poderia fazer uma separação desses alunos, mas depois percebeu que era possível trabalhar igualmente com todos os alunos, fazendo as adequações necessárias. A professora Tulipa acredita que os alunos têm avançando e se desenvolvido, pois a informática ajuda na coordenação motora e na socialização.

A professora Rosa, além de trabalhar com materiais concretos no ensino das crianças com deficiência intelectual, também acredita na tecnologia como auxílio à estratégia pedagógica. Ela narra:

"Eu tinha um aluno com deficiência intelectual que tinha muitas dificuldades em aprender. Ele tinha uma letra ilegivel, sabia ler um pouco, agora escrever não. Mas ele gostava muito de celular. Todo mundo proibia o celular. Aí, eu passei a ver o celular como um recurso. Ele digitava no celular usando a página de texto. Eu falava com ele: 'Tudo bem, eu deixo você escrever o que está escrito no quadro no celular'. Então, ele digitava, lia para mim. Aí, ele passou a trazer o tablet. Então, ficou mais fácil digitar no tablet. Isso foi um recurso. A tecnologia, atualmente, eu utilizo muito o laboratório de informática. Também utilizo, com estratégia pedagógica, o concreto. Concretagem é que a gente sempre tem na escola. Temos o material dourado para fazer contagem, palitinhos, canudos pra fazer montagem e contagem também, jornais onde recorta muitas palavras, principalmente, trabalhamos as dificuldades ortográficas, os blocos geométricos, dominós. Tem dominós da adição, dominós da subtração."

Podemos refletir sobre o quanto é importante a figura do mediador, além dos instrumentos disponibilizados para a criança. Desta forma, o professor está oportunizando a aprendizagem quando oferece materiais diversificados. A professora Rosa utilizou como estratégia pedagógica o celular, que a ajudou no seu trabalho pedagógico, e teve êxito na sua ação (Toledo \& Martins, 2009).

A professora Gardênia narra suas estratégias pedagógicas, porém comenta sobre as dificuldades de recursos pedagógicos oferecidos pela rede do DF, bem como a tensão em se trabalhar com muitas crianças ao mesmo tempo na sala de aula.

"A gente tenta trabalhar no lúdico. Só que, quando você começa a trabalhar com eles ludicamente, na sala inclusiva, os outros alunos sem deficiência também querem. Mas não tem material para todo mundo! Você não tem como atender todos os alunos do mesmo jeito. Você precisa dar andamento em mais conteúdos com outros. [...]. Uma estratégia que eu usava era fazer um grupinho, onde o aluno com deficiência intelectual pudesse ser inserido. Elegia este aluno como um voluntário, que assumisse alguma atividade diária." 
Novamente observamos que a professora Açucena utiliza, também, várias estratégias pedagógicas no intuito de ensinar as crianças a aprender e se desenvolver. Porém ela acredita ser um grande desafio o processo de ensino e aprendizagem. Verificamos no seu relato:

"O desafio é ensiná-los (referindo-se ao ensino da criança com deficiência intelectual). Fazer com que eles aprendam a ler. Principalmente nós, professores que trabalhamos com alfabetização. A gente fica mais na leitura, na matemática básica. Geralmente, esses alunos têm dificuldade em socializar, e o professor tem o desafio de colocar ele dentro do grupo, de inserir nas brincadeiras dos coleguinhas."

Neste contexto, a professora Orquídea acredita que é importante não só a utilização das estratégias pedagógicas, mas também a sociabilização. Ela narra:

"Você tem que saber como lidar com as diferenças. Você tem que aprender a lidar com o ritmo daquela criança. Você tem que ter um ritmo com uma criança, outro ritmo com outra criança. Tem que trabalhar o social de uma turma inteira pra conseguir receber o aluno com deficiência intelectual."

Silva e Tavares (2009) acreditam que proporcionar um ambiente estimulador e facilitador da aprendizagem é um fator importante para o ensino da criança com deficiência intelectual. A sociabilização da criança no contexto da educação inclusiva agrega, neste aluno, o valor do outro, pois possibilita a sua presença no grupo e nos papéis representativos que assume no seu cotidiano.

Observamos também, na análise das entrevistas, que a aproximação do professor na intenção de transmitir confiança é importante como estratégia pedagógica para o aprendizado do aluno com deficiência intelectual. Podemos verificar no relato da professora Açucena.

"Uma estratégia que utilizo é conversar com eles (referindo-se ao aluno com deficiência intelectual incluído), de fazer amizade, de estar junto, para que eles tenham confiança, né? Se não for feita esta aproximação, eles não vão confiar e nem vão fazer nenhuma atividade que você pede. Geralmente, eles não querem muito fazer as atividades. Mas quando eles têm confiança, eles fazem."

Compreendemos com a análise desta narrativa que a interação diária do professor com seu aluno com deficiência intelectual incluído, no ambiente escolar, deve ser baseada numa relação espontânea, autêntica e comprometida, para uma fluida comunicação de trocas que torne possível ao professor compreender seu aluno, suas necessidades, suas possibilidades, suas defesas. A partir daí podemos pensar em desenvolver ações pedagógicas voltadas para um trabalho que promova seu desenvolvimento (Silva \& Tavares, 2009). 
Nesta mesma linha, observamos que o vínculo é muito importante para a aproximação do professor com seu aluno. Orquídea narra:

"Outra coisa importante é que quando a criança ou o adulto com deficiência intelectual se identifica com o professor, e sabe que ele é importante para o professor, o resultado dele é maior, é mais rápido."

Podemos observar, na sua narrativa, que a relação entre a professora e o aluno é essencial para que este possa se interessar pelas atividades propostas. Para isso, é importante que o professor promova estratégias pedagógicas que atendam as especificidades do seu aluno e o incentivem a realizar a tarefa, dentro do seu tempo. Desta forma, se faz necessária a compreensão do professor e o entendimento que seu aluno realiza a atividade conforme a sua dinâmica. Neste sentido, Caldas e Souza (2014) entendem que "para ocorrer aprendizagem é preciso que se estabeleçam vínculos afetivos capazes de conduzir a atenção dos processos intelectuais aos objetos de conhecimento" (p. 19).

Outro ponto observado na análise dos dados foi a opinião das professoras em relação à inclusão, em seus aspectos positivos e negativos ${ }^{13}$. Constatamos que existe um sentimento de aceitação e otimismo. Em muitos relatos verificamos que o processo inclusivo ainda está incipiente, precisando de muitas modificações para que o professor possa contribuir de forma mais eficaz para o desenvolvimento dos alunos com deficiência intelectual.

A professora Açucena acredita na inclusão da seguinte forma:

"Acho que a inclusão ainda não deu certo, completamente. Eu acho que tá caminhando, mas não atingiu ainda o pleno. Eu acredito que ainda tá no processo, não atingiu ainda não."

Podemos observar também uma credibilidade no processo de inclusão, como narrado pela professora Açucena.

“Eu acredito na inclusão. Nem todos os alunos podem ser incluídos, eu acredito que não! Mas a maioria sim. Eu acredito que ainda tem aluno que precisa de um atendimento mais individualizado."

Vimos que ocorre um sentimento de crédito em relação à inclusão, mas com ressalvas. Pensamos que estes sentimentos inconclusos podem ser frutos de uma implementação de políticas públicas inclusivas sem planejamento eficiente que promovesse um real crédito por parte dos professores.

\footnotetext{
${ }^{13} \mathrm{~A}$ partir daqui as análises serão mais descritivas porque elas se referem especificamente às experiências e opiniões das entrevistadas que não foram comparadas com um estudo abrangente na rede de ensino do DF.
} 
Esta observação também pode ser verificada no relato da professora Violeta, que acredita na inclusão, mas admite que deve melhorar muito, como é constatado na sua fala:

"Eu acredito na inclusão. Apesar de ter algumas resistências. Mas eu acredito sim. Porém não atingiu os cem por cento. Eu acho que setenta por cento. Ainda precisa melhorar muita coisa. Eu acho que tem que melhorar a questão do atendimento individualizado para o aluno com deficiencia intelectual."

No entanto, a professora Orquídea compartilha a opinião positiva sobre a inclusão sem ressalvas, como é visto na sua fala:

"Acredito que, mesmo com a dificuldade do professor, de não estar dando tanta atenção para o aluno com deficiência intelectual, de tratá-lo como mais um na sala, tem os amigos, que querem ajudar. Tem, também, as relações sociais, tem a vivência. A inclusão tem muitos pontos positivos."

Quanto aos pontos positivos e negativos da inclusão também foram diversos os relatos. Porém, as professoras acreditam que houve grandes avanços durante esses anos desde a implementação das políticas públicas inclusivas. Como relata a professora Açucena:

"Bom, para mim a inclusão, no começo, não foi boa. No início, foi muito tumultuado, foi jogado de qualquer jeito. A gente não tinha orientação nenhuma sobre inclusão. A ideia era tirar os meninos do centro e jogar na escola, jogar mesmo! O professor não tinha orientação nenhuma. Eu acho que demorou muito para eles tomarem providência em relação às turmas inclusivas. Antes de redução de turma, de equipe para trabalhar nas escolas. Houve muita demora para acontecer. Depois, começou a ter as equipes. As professoras da equipe trabalhavam bastante, pois atendiam a várias escolas."

A professora Orquídea, por sua vez, acredita que um ponto positivo da inclusão é oportunizar a socialização. Um ponto negativo seria o atendimento, que deveria ser mais específico e prolongado, dependendo de cada caso.

"Os pontos positivos são maiores, na minha opinião, que os pontos negativos. Então, nos pontos positivos, a criança tem oportunidade de desenvolver junto com os outros, mesmo com a suas dificuldades. A criança com deficiência intelectual tem oportunidade de sanar suas dificuldades. [...]. Tem a oportunidade de estar, ali, no meio dos outros alunos, de participar, de ter mais vivência. Diferente de uma sala de ensino especial, que sozinho não teria tanta probabilidade para se desenvolver como teria oportunidade de se desenvolver numa turma inclusiva. Agora, por outro lado, colocar uma criança que tenha uma necessidade muito grave, como uma criança com deficiência intelectual grave, numa turma de ensino regular inclusivo, não é bom nem para criança, naquele primeiro momento, e nem para a turma. Alguns aspectos 
da criança, um exemplo, nos casos mais graves, teria que ser realmente trabalhada antes para depois tentar a inclusão. Não pegar a criança e jogar direto na turma inclusiva, pois o professor não dá conta. Mas eu sou favorável. A inclusão é necessária."

Ao analisarmos as entrevistas das professoras neste eixo $\mathrm{B}$, depreendemos que é importante, no contexto escolar inclusivo, ocorrer uma relação aluno-professor que promova um ensino-aprendizado de qualidade e adequado às necessidades do aluno com deficiência intelectual, colaborando com a sua participação e interação, promovendo confiança na realização das atividades.

Vimos também que as educadoras, algumas vezes, podem se sentir sozinhas nesta caminhada da educação inclusiva, porém lhes cabe sempre repensar suas práticas pedagógicas, assim como suas estratégias pedagógicas, adequando o currículo às necessidades específicas de cada aluno, tornando possível o conhecimento sem distinção, proporcionando um ambiente estimulante para promover o aprendizado (Silva \& Tavares, 2009). 


\section{Capítulo 5 -Considerações finais}

“A criança cujo desenvolvimento está complicado pelo 'defeito' não é simplesmente uma criança menos desenvolvida que uma criança normal, mas sim desenvolvida de outro modo." (Vigotski, 19342012, p. 12, tradução nossa).

Este trabalho procurou analisar o impacto das políticas públicas inclusivas na dinâmica educativa que envolveu professores que tenham alunos com deficiência intelectual nas escolas da rede pública do Distrito Federal. Ateve-se às modificações provocadas pela implementação destas políticas no cotidiano escolar, tanto na formação docente quanto na reflexão sobre o espaço educacional, mais especificamente, sobre o que ocorreu nos últimos vinte anos.

O início da implementação das políticas públicas inclusivas ocorreu, na SEEDF, de forma desconectadada realidade dos educadores e dos educandos, levando à resistência e ao medo dos docentes; um descrédito dessa nova modalidade educacional introduzida no ambiente escolar.

Tal mudança trouxe a necessidade de rever os parâmetros educacionais, tanto em termos de estrutura quanto em termos pedagógicos, exigindo adequações e mudanças que não foram devidamente implantadas, em momento inicial, pelo poder público. Os relatos evidenciama desigualdade dos processos formativos docentes sobre as políticas que foram implementadas, devido à heterogeneidade da divulgação e da preparação pedagógica para o atendimento aos educandos com deficiência intelectual. Observamos uma clara disparidade temporal entre a efetivação das políticas públicas de inclusão escolar aplicadas pelo governo distrital e o início da atividade das docentes entrevistadas com o processo inclusivo.

Em relação à disparidade temporal discutida,percebemos uma falta de entendimento, por parte dos docentes, sobre a nomenclatura que se instituía na época da implementação das políticas públicas de inclusão, pois, ao se voltar para a história da educação especial, como foi demonstrado no primeiro capítulo desta pesquisa, podemos notar que, em 1994, depois da Declaração de Salamanca, houve uma substituição do modelo integracionista pelo inclusivista. Porém, no Brasil,ocorreu uma confusão na tradução do documento, no qual se percebia uma orientação integradora. Somente após 2007, essa tradução é alterada pelo $\mathrm{CORDE}^{14}$, que substitui o termo "integração"por"inclusão", causando, portanto, um dilema conceitual e de

\footnotetext{
${ }^{14}$ CORDE - Coordenadoria Nacional para Integração da Pessoa Portadora de Deficiência.
} 
fundamentação política na época da implementação das políticas inclusivas (Garcia \& Michels, 2011).

O processo inclusivo teve como um de seus resultados uma necessidade, por parte dos professores, de procurar uma formação continuada que os preparasse para uma prática educativa que atendesse às especificidades do aluno com deficiência intelectual. Ao longo desse tempo, o conhecimento acumulado pelas educadoras só se deu pelo interesse pessoal de cada uma delas em aprimorar-se no seu trabalho e em desenvolver estratégias pedagógicas que desenvolvessem o ensino-aprendizagem na perspectiva inclusiva para os alunos com deficiência intelectual. Conclui-se a partir disso a necessidade de uma formação continuada que aprimore a prática educacional no contexto da inclusão.

Nessa tônica, Pletsch (2009) acredita que os professores, no geral, não estão preparados para dar aulas para alunos com deficiência, apesar de acreditar na inclusão. Odespreparo e a falta de conhecimento comungam com a formação inicial ou continuada que o professor recebeu.Sendo assim, razões diversas podem ser decisivas para que o professor, mesmo sem interesse real em trabalhar com as crianças com deficiência, venha a querer pegar turmas inclusivas. Em sua pesquisa, Pletsch (2009) afirma que:

Diversos estudos mais recentes têm reafirmado a necessidade da melhoria da formação de professores como condição essencial e premente para a promoção eficaz da inclusão de alunos com necessidades especiais em rede regular de ensino (Bueno, 1999; Carneiro, 1999; Magalhães, 1999; Glat, 2000; Nogueira, 2002 e 2003; Ferreira; Glat; Pletsch, 2004; Pletsch, 2005; Glat; Pletsch, Oliveira; Antunes, 2006). Não é para menos. A realidade evidenciada por uma pesquisa recente em âmbito nacional mostrou que os professores, de maneira geral, não estão preparados para receber em sua sala de aula alunos especiais. (p. 147)

No eixo B, foram discutidas as estratégias pedagógicas utilizadas pelas docentes no ensino dos alunos com deficiência intelectual, das quais se observa um repertório de elementos didáticos voltados prioritariamente para a ludicidade e o concretismo, além da ênfase nos aspectos da socialização e aprendizado, por meio da construção da confiança do educando no educador.

Analisamos, a partir das experiências e das narrativas apresentadas pelas educadoras, acerca das políticas públicas inclusivas distritais nos últimos vinte anos, que há um crédito, por parte das professoras, no processo inclusivo, tendo como exemplos a inserção e a sociabilização dos alunos no contexto escolar regular, afastando-os do modelo pedagógico segregacional. Todo esse panorama possibilitou um desenvolvimento dos professores, conforme observamos nos 
dados construídos nesta pesquisa. Além disso, um evidente crescimento da aceitação da comunidade escolar, bem como uma clara mudança nas políticas educacionais. Contudo, as educadoras salientam que há a necessidade de transformações de base que promovam e desenvolvam a inclusão em aspectos estruturais do ambiente escolar e de formação docente, desde a graduação.

Podemos contribuir para o campo da Psicologia do desenvolvimento humano no que tange ao que foi observado nas análises dos dados quanto ao desenvolvimento que as professoras tiveram ao longo desses últimos vinte anos de atuação no ensino inclusivo de crianças com deficiência intelectual, demonstrando que o trabalho docente realizado trouxe uma mudança de comportamento e postura, que antes não tinham, além de promover um olhar mais profundo para o outro e um despertar para a necessidade de formação continuada para que pudessem realizar um trabalho que promovesse o desenvolvimento destas crianças.

Portanto, neste trabalho, promoveu uma reflexão que procurou trazer luz ao processo de implementação da inclusão nas escolas públicas do Distrito Federal, inspirado em entrevistas realizadas com educadoras que participaram, nos últimos vinte anos, da aproximação de ambientes e públicos escolares até então díspares e separados. Embora tenha se voltado às experiências docentes nos últimos vinte anos, dentro da rede pública do Distrito Federal, este trabalho pretende, dentro do seu escopo limitado, servir como degrau para uma análise desse processo inclusivo com outras deficiências, em outras unidades da federação, ou até no Brasil, de modo a abrir possibilidades e alternativas de pesquisa que ampliem, aprofundem e enriqueçam esse tema, para possibilitar uma compreensão mais acurada desse fenômeno educacional. Por fim, tencionamos ampliar a discussão sobre as formas e as possibilidades da inclusão, no intuito de trazer melhorias nesse processo de ensino-aprendizagem, além de abrir caminhos para outras pesquisas que abranjam essa temática sob outras perspectivas, detectando possíveis falhas e promovendo aperfeiçoamento desse processo inclusivo, não só no Distrito Federal, mas em todo o Brasil. 


\section{Referências Bibliográficas}

Abreu, F. S. D. de (2015). Experiências linguísticas e sexuais não hegemônicas: um estudo das narrativas de surdos homossexuais (Dissertação de mestrado). Universidade de Brasília, Brasília.

Alonso, M. Á. V., \& Schalock, R. L. (2010). Últimos avances em el enfoque y concepción de las personas com discapacidad intelectual. Revista Espanhola sobre Discapacidad Inteletual,

41(4), 7-21. Recuperado de http://www.sindromedown.net/adjuntos/cEnlacesDescargas/611_1_ultimos.pdf.

American Association on Intellectual and Developmental Disabilities. (2011). (11a ed.). Recuperado de http://www.americanbar.org/content/dam/aba/publications/supreme_court_preview/briefsv2/12-10822_amicus_pet_aaidd.authcheckdam.pdf.

American Psychiatric Association. (2014). Manual Diagnóstico e Estatístico de Transtornos Mentais (5a ed.). Porto Alegre: Artmed.

Anache, A. A. (2001). Reflexões sobre o diagnóstico psicológico da deficiência mental utilizado em educação especial. Mato Grosso do Sul: UFMS.

Asbahr, F. da S. F. (2005). A pesquisa sobre a atividade pedagógica: contribuições da teoria da atividade. Revista Brasileira de Educação,29, 108-118.

Barbosa, E. T., \& Souza, V. L. T. de (2010). A vivência de professores sobre o processo de inclusão: um estudo da perspectiva da Psicologia Histórico-Cultural. Revista Psicopedagogia, 27(84), 352-62.

Bareta, M. S., \& Viana, P. B. de M. (2014). Os benefícios da inclusão de alunos com deficiência em escolas regulares. Revista Pós-graduação: Desafios Contemporâneos, 1(1).

Barroco, S. M. S. (2007). A educação especial do novo homem soviético e a psicologia de L. S. Vigotski: implicações e contribuições para a psicologia e a educação atuais (Tese de doutorado). Universidade Estadual Paulista Júlio de Mesquita Filho, Campus Araraquara, São Paulo, Brasil.

Bauer, M. W., \& Gaskell, G. G. (2000). Pesquisa qualitativa com texto, imagem e som: um manual prático (5a ed.). Rio de Janeiro: Vozes. 
Bayer, H. O. (2005). Por que Lev Vigotski quando se propõe uma educação inclusiva? Revista do Centro de Educação, $16 . \quad$ Recuperado de http://coralx.ufsm.br/revce/ceesp/2005/02/a7.htm.

Bezerra, G. F., \& Araújo, D. A. de C. (2011). De volta à teoria da curvatura da vara: a deficiência intelectual na escola inclusiva. Educação em Revista, 27(2), 277-302.

Bianchetti, L. (1998).Aspectos históricos da apreensão e da educação dos consideradas pessoas com deficiência. In L. Bianchetti \& I. M. Freire. Um olhar sobre a diferença: interação, trabalho e cidadania (pp. 21-51). São Paulo: Papirus.

Bíblia (2009). A Bíblia da Mulher: leitura, devocional, estudo (2a ed). Barueri, SP: Sociedade Bíblica do Brasil.

Bridi, F. R. de S., \& Baptista, C. R. (2014). Deficiência mental: o que dizem os manuais diagnósticos? Revista Educação especial,27(49), 499-512.

Buccio, M. I. da S. (2007). Políticas públicas de educação inclusiva: a implementação em escolas públicas no município de Araucária-PR (Dissertação de mestrado). Universidade Tuiuti do Paraná, Curitiba, Brasil.

Caldas, R. F. L., \& Souza, M. P. R. de (2014). Recuperação escolar: uma análise crítica a partir da Psicologia Escolar. Revista Quadrimestral da Associação Brasileira de Psicologia Escolar e Educacional, 18(1), 17-25.

Câmara, A. M. C. S. et al. (2012). Percepção do processo saúde-doença: significados e valores de educação em saúde. Revista Brasileira de Educação Médica,36(1), 40-50.

Canguilhem, G. (1982). O normal e o patológico. Rio de Janeiro: Forense-Universitária.

Carmo, A. A. do (1991). Deficiência Física: A Sociedade Brasileira Cria, "Recupera" e Discrimina. Brasília: Secretaria dos Desportos/PR.

Carvalho, E. N. S. de, \& Maciel, D. M. M. de A. (2003). Nova concepção de deficiência mental segundo a American Association on Mental Retardation - AAMR: sistema 2002. Temas em Psicologia da SBP,11(2), 147-156.

Coelho, C. M. M. (2010). Inclusão escolar. In D. A. Maciel\& S. Barbato (Eds.), Desenvolvimento humano, educação e inclusão escolar (pp. 55-72). Brasília: Editora UnB. 
Coelho, M. T. A. D., \& Almeida Filho, N. de (2002). Conceito de saúde em discursos contemporâneos de referência científica. História, Ciências, Saúde - Manguinhos, 9(2), 31533.

Conselho de Educação do Distrito Federal (2014). Resolução n. 1/2012 - CEDF (alterada em seus dispositivos pela Resolução n. 1/2014 - CEDF, publicada no DODF n. 43, de 26 de fevereiro de 2014, p. 5). Brasília. Recuperado em 5 maio 2016, de www.cre.se.df.gov.br/ascom/documentos/.../part_resolucao_1_2012_alterada.pdf.

Constituição da República Federativa do Brasil de 1988. (1988). Brasília: Imprensa Oficial.

Cunha, M. L., Cunha, N. V. S., \& Ayres, N. S. da (2013). A defectologia de Vigotski e a educação da criança cega. Revista Formar Interdisciplinar, 1(2), 6-11.

Cunha, M. L., Cunha, N. V. S., \& Silva, N. A. da (2013). A defectologia de Vigotski e a educação da criança cega. Revista Formar Interdisciplinar, 1(2), 6-11.

Cunha, N. V. S., Ayres, N., \& Moraes, B. (2010). A teoria da compensação em Adler e em Vigotski [Número especial]. Revista Eletrônica Arma da Crítica, 2.

Dainéz, D. (2009). A inclusão escolar de crianças com deficiência mental: focalizando a noção de compensação na abordagem histórico-cultural (Dissertação de mestrado). Universidade Metodista de Piracicaba, Piracicaba, Brasil.

Dechichi, C. (2011). Princípios e fundamentos da educação especial. Uberlândia: Universidade Federal de Uberlândia.

Declaração de Salamanca sobre princípios, política e práticas na área das necessidades educativas especiais. (1994). Brasília: Unesco.

Dias, C. A. (2000). Grupo Focal: técnicas de coletas de dados em pesquisas qualitativas. Informação Sociedade,10(2).

Dias, S. de S. (2014). A quem serve o diagnóstico de deficiência intelectual?: Um estudo do desenvolvimento adulto na perspectiva da psicologia dialógica (Tese de doutorado). Universidade de Brasília, Brasília, Brasil.

Fonseca, K. de A. (2011). Análise de adequações curriculares no ensino fundamental: subsídios para programas de pesquisa colaborativa na formação de professores (Dissertação de mestrado). Universidade Paulista Júlio de Mesquita, Bauru, Brasil. 
Fontana, R., \& Cruz, N. (1997). Abordagem histórico-cultural. In R. Fontana \& N. Cruz, Psicologia e trabalho pedagógico. São Paulo: Atual.

Fundo das Nações Unidas para a Infância. (1948). Declaração Universal dos Direitos Humanos. Recuperado em 5 maio 2016, de https://www.unicef.org/brazil/pt/resources_10133.html.

Fundo das Nações Unidas para a Infância. (1990). Declaração Mundial sobre Educação para Todos. Recuperado em 5 maio 2016, de https://www.unicef.org/brazil/pt/resources_10230.html.

Garcia, R. M. C., \& Michels, M. H. (2011). A política de educação especial no Brasil (19912011): uma análise da produção do GT15 - educação especial da ANPED. Revista Brasileira. Ed. Especial, 17, 105-124.

Glat, R., \& Fernandes, E. M. (2005). Da educação segregada à educação inclusiva: uma breve reflexão sobre os paradigmas educacionais no contexto da educação especial brasileira. Revista Inclusão, (1).

Glat, R., Mascaro, C. A., Antunes, K. C. V., \& Marin, M. (2011). Inclusão de pessoas com deficiência e outras necessidades especiais na escola e no trabalho. Recuperado de http://www.sjp.pr.gov.br/wpcontent/uploads/2013/04/CIEE_texto_GLAT_et_all_versao_final_agosto_2011.pdf.

Glat, R., \& Nogueira, M. L. de L. (2003). Políticas educacionais e a formação de professores para a educação inclusiva no Brasil. Comunicações. Caderno do Programa de PósGraduação em Educação, 10(1), 134-141.

Góes, M. C. R. de\&Laplane, A. L. F. de Laplane (Orgs.).Políticas e práticas de educação inclusiva. 4a ed., Campinas: Autores Associados.

Jannuzzi, G. (1985). A luta pela educação do as pessoas com deficiência intelectual no Brasil. São Paulo: Cortez: autores Associados.

Jannuzzi, G. (2004). Algumas concepções de educação do deficiente. Revista Brasileira deCiências do Esporte, 25(3), 9-25.

Jesus, D. M. de,\& Effgen, A. P. S. (2012). Formação docente e práticas pedagógicas: conexões, possibilidades e tensões. In T. G. Miranda \&T. A. Galvão Filho (Eds.), O professor e a educação inclusiva: formação, práticas e lugares. Salvador: EDUFBA. 
Karagiannis, A., Stainback, W.,\& Stainback, S. (1999). Fundamentos do Ensino Inclusivo. In S. Stainback \& W. Stainback (Orgs.),Visão Geral Histórica da Inclusão (pp. 35-47). Porto Alegre: Artes Médicas Sul.

Kassar, M. de C. M. (2011). Educação especial na perspectiva da educação inclusiva: desafios da implementação de uma política nacional. Educar em Revista, (14), 61-79.

Kassar, M. de C. M. (2013). Matrículas de crianças com necessidades educacionais especiais na rede de ensino regular: do que e de quem se fala? In M. C. R. de Góes \&A. L. F. de Laplane (Eds.),Políticas e práticas de educação inclusiva (4a ed., pp. 47-64). Campinas: Autores Associados.

Kassar, M. de C. M. (2014). A formação de professores para educação inclusiva e os possíveis impactos na escolarização de alunos com deficiência. Caderno Cades, 34(93), 207-224.

Kelman, C. (2010). Sociedade, educação e cultura. In D. A. Maciel \&S. Barbato (Eds.), Desenvolvimento humano, educação e inclusão escolar (pp. 11-53). Brasília: Editora UnB.

Kohatsu, L. N. (2003). O preconceito na escola especial. In M. C. Marquezine, M. A. Almeida, \&E. Tanaka, Educação Especial: políticas públicas e concepções sobre deficiência (pp. 125130). Londrina: Eduel.

Laplane, A. L. F. de (2013). Notas para uma análise dos discursos sobre inclusão escolar. In M. C. R. de Góes\& A. L. F. de Laplane (Orgs.),Políticas e práticas de educação inclusiva (4a ed., pp. 5-18). Campinas: Autores Associados.

Lei n. 13.146, de 6 de julho de 2015. (2015). Institui a Lei Brasileira de Inclusão da Pessoa com Deficiência (Estatuto da Pessoa com Deficiência). Recuperado em 5 maio 2016, de http://www.planalto.gov.br/ccivil_03/_ato2015-2018/2015/Lei/L13146.htm.

Lei n. 7.853/1989, de 24 de outubro de 1989. (1989). Dispõe sobre o apoio às pessoas portadoras de deficiência, sua integração social, sobre a Coordenadoria Nacional para Integração da Pessoa Portadora de Deficiência - Corde, institui a tutela jurisdicional de interesses coletivos ou difusos dessas pessoas, disciplina a atuação do Ministério Público, define crimes, e dá outras providências. Recuperado em 5 maio 2016, de http://www.planalto.gov.br/ccivil_03/leis/17853.htm.

Lei n. 8.069, de 13 de julhode 1990. (1990). Dispõe sobre o Estatuto da Criança e do Adolescente e dá outras providências. Brasília. 
Lei n. 9.394, de 20 de dezembro de 1996. (1996). Estabelece as diretrizes e bases da educação nacional. Brasília.

Leontiev, A. (1991). Os Princípios do desenvolvimento mental e o problema do atraso mental. In A. R. Luria et al.,Psicologia e pedagogia 1: bases psicológicas da aprendizagem e do desenvolvimento(2a ed., pp. 99-119). Lisboa: Estampa.

Lima, N. A. C.; Araújo, A. C. B.\& Moraes, B. (2010). Problemas fundamentais da defectologia: aproximações preliminares à luz do legado de Vigotski. Revista Eletrônica Arma da Crítica. Ano 2 [Número Especial]. Dez, ISSN 1984-4735.

Lopes, N. A. (2005). Deficiência e inclusão escolar: um estudo sobre representações sociais(Dissertação de mestrado). Universidade de Brasília, Brasília, Brasil.

Luria, A. R. (1991). Curso de Psicologia Geral: Introdução evolucionista à psicologia (Vol. 1). Rio de Janeiro: Civilização Brasileira.

Marques, C. A. (1997). Integração: uma via de mão dupla na cultura e na sociedade. In M. T. E. Mantoan et al. (Orgs.),A integração de pessoas com deficiência: contribuições para uma reflexão sobre o tema (pp. 18-23). São Paulo: Memnon Senac.

Martins, L. M. (2015). As aparências enganam: divergências entre o materialismo histórico dialético e as abordagens qualitativas de pesquisa. In S. C. Tuleski, M. Chaves, \& H. A. Leite. Materialismo histórico dialético como fundamento da psicologia histórico-cultural: método e metodologia de pesquisa. Maringá: Eduem.

Martins, L. M. B., Tacca, M. C. V. R.,\& Kelman, C. A. (2009). Vigotsky: a inclusão e a educação bilíngue dos surdos. Anais do V Congresso Multidisciplinar de Educação Especial, Londrina, Brasil, 2906-2914.

Medeiros, M. V., \& Cabral, C. L. de O. (2006). Formação docente: da teoria à prática, em uma abordagem sócio-histórica. Revista E-Curriculum, 1(2).

Mendes, E. G. (2010). Breve histórico da educação especial no Brasil. Revista Educación Y Pedagogía, 22(57).

Mendonça, F. L. de R. (2013). Entre concepções docentes e práticas pedagógicas: O processo de inclusão de alunos com deficiência intelectual na rede pública de ensino do Distrito Federal (Dissertação de mestrado). Universidade de Brasília, Brasília, Brasil.

Mendonça, F. L. de R., \& Silva, D. N. H. (2015). Formação docente e inclusão: para uma nova metodologia. Curitiba: Appris. 
Ministério da Educação. Parâmetros Curriculares Nacionais $-1^{a} a 4^{a}$ série. Recuperado em 5 maio 2016, de http://portal.mec.gov.br/pnld/195-secretarias-112877938/seb-educacaobasica-2007048997/12640-parametros-curriculares-nacionais-1o-a-4o-series.

Ministério da Educação e do Desporto. (1994). Política Nacional de Educação Especial. Brasília: MEC/SEESP.

Ministério da Educação/SECADI. (2013). Política Nacional de Educação Especial na Perspectiva da Educação Inclusiva. Brasília.

Moreira, A. U. (2015). "Brincante é um estado de graça": sentidos do brincar na cultura popular (Dissertação de mestrado). Universidade de Brasília, Brasília, Brasil.

Moretti, V. D., Asbahr, F. da S. F., \& Rigon, A. J. (2011). O humano no homem: os pressupostos teórico-metodológico da teoria histórico-cultural. Psicologia \& Sociedade, 23(3), 477-485.

Netto, N. B., \& Leal, D. (2013). Contribuições para uma historiografia da defectologia soviética. Nuances: Estudos sobre Educação, 24(1), 73-91. doi: 10.14572/nuances.v24i1.2156

Nicolau, M. R. (2011). Os impactos das políticas de inclusão escolar na formação e na prática de professores (Dissertação de mestrado). Universidade Metodista de São Paulo, São Bernardo do Campo, Brasil.

Nuernberg, A. H. (2008). Contribuições de Vigotski para a educação de pessoas com deficiência visual. Psicologia em Estudo, 13(2), 307-316.

Oliveira, A. A. S. de, \& Leite, L. P. (2007). Construção de um sistema educacional inclusivo: um desafio político pedagógico. Ensaio: aval. Pol. Públ. Educ., 15(57), 511-524.

Oliveira, M. C. S. L. de (2012). Narrativas e desenvolvimento da identidade profissional de professores. Caderno Cades, 32(88), 369-378.

Oliveira, M. C. S. L. de,\& Vieira, A. O. M. (2006). Narrativas sobre a privação de liberdade e o desenvolvimento do self adolescente. Educação e Pesquisa, 32(1), 67-83.

Oliveira, M. K. de. (1997). Vigotsky: Aprendizado e Desenvolvimento um Processo SócioHistórico (4a ed.). São Paulo: Scipione.

Oliveira, M. K. de, Rego, T. C.,\& Aquino, J. G. (2006). Desenvolvimento psicológico e constituição de subjetividades: ciclos de vida, narrativas autobiográficas e tensões da 
contemporaneidade. Pro-Posições, 17(2), 119-138.

Organização Mundial da Saúde (OMS) (1948).Administração da OMS. Recuperado de, http://www.who.int/governance/en/index.html.

Orientação Pedagógica (OP DF) (2010). Educação Especial. Governo do Distrito Federal, Secretaria de Estado de Educação do Distrito Federal, Brasília.

Padilha, A. M. L. (2004). Possibilidades de histórias ao contrário, ou, como desencaminhar o aluno da classe especial (3a ed.). São Paulo: Plexus.

Padilha, A. M. L. (2007). Práticas pedagógicas na educação especial: a capacidade de significar o mundo e a inserção cultural do as pessoas com deficiência intelectual (4a ed.). Campinas: Autores Associados.

Padilha, A. M. L. (2015). Educação inclusiva: já se falou muito sobre ela? [Edição especial]. Educação em Foco, 313-332.

Pessotti, I. (1984). Deficiência Mental: da superstição à ciência. São Paulo: Ed. da Universidade de São Paulo.

Pimentel, S. C. (2012). Formação de professores para inclusão: saberes necessários e percursos formativos. In T. G. Miranda \& T. A. Galvão Filho (Eds.), O professor e a educação inclusiva: formação, práticas e lugares. Salvador: EDUFBA.

Pino, A. (2000). O social e o Cultural na Obra de Vigotski. Educ. Soc., (71), 45-78.

Pino, A. (2005). As marcas do humano: às origens da construção cultural da criança na perspectiva de Lev S. Vigotski. São Paulo: Cortez.

Platão (1997). A República. São Paulo: Nova Cultural.

Platt, A. D. (1999). Uma contribuição histórico-filosófica para a análise do conceito de deficiência. Ponto de Vista, 1(1), 71-80.

Pletsch, M. D. (2009). A formação de professores para a educação inclusiva: legislação, diretrizes políticas e resultados de pesquisas. Educar, (33), 143-156.

Pletsch, M. D. (2014). Educação especial e inclusão escolar: políticas, práticas curriculares e processos de ensino e aprendizagem. Educação Especial e Inclusão Escolar. 
Pletsch, M. D. (2014a). A escolarização de pessoas com deficiência intelectual no Brasil: da institucionalização às políticas de inclusão (1973-2013). Arquivos analíticos de políticas educativas (aape), 22(81).

Reis, R. L., \& Ross, P. R. (2008). A inclusão do aluno com deficiência no Ensino Regular. Diaa-dia Educação. Recuperado de www.diaadiaeducacao.pr.gov.br/portals/pde/arquivos/22168.pdf.

Resende, D. O., Ferreira, P. M., \& Rosa, S. M. (2010). A inclusão escolar de crianças e adolescentes com necessidades educacionais especiais: um olhar das mães. Cadernos de Terapia Ocupacional da UFSCar, 18(2), 115-127.

Rigon, A. J., Asbahr, F. D. S. F., \& Moretti, V. D. (2010). Sobre o processo de humanização. In M. O. Moura (Ed.), A atividade pedagógica na teoria histórico-cultural (pp. 13-44). Brasília: Liber Livro.

Rozek, M. (2009). A educação especial e a educação inclusiva: compreensões necessárias. Reflexões e Ação, 1, 164-183.

Sanches-Ferreira, M., Lopes-dos-Santos, P., \& Santos, M. A. (2012). A desconstrução do conceito de deficiência mental e a construção do conceito de incapacidade intelectual: de uma perspectiva estática a uma perspectiva dinâmica da funcionalidade [Edição especial]. Revista Brasileira, 18(4), 553-568.

Sassaki, R. K. (1997). Inclusão: constituindo uma sociedade para todos (3a ed.). Rio de Janeiro: WVA.

Scliar, M. (2007). História do conceito de saúde. Physis: Revista Saúde Coletiva, 17(1), 29-41.

Secretaria de Educação Especial/Ministério da Educação. (2008). Inclusão -Revista da Educação Especial, 4(1).

Secretaria Municipal de Educação de São Paulo/Diretoria de Orientação Técnica. (2008). Referencial sobre avaliação da aprendizagem na área da deficiência intelectual. São Paulo: SME/DOT.

Silva, A. P. M. da, \& Arruda, A. L. M. M. (2014). O papel do professor diante da inclusão escolar. Revista Eletrônica Saberes da Educação, 5(1).

Silva, C. M. da. (2014). Processos de escolarização no Distrito Federal: o que dizem os profissionais da escola sobre a inclusão de surdos? (Dissertação de mestrado). Universidade de Brasília, Brasília, Brasil. 
Silva, D. N. H., Ribeiro, J. C. C., \& Mieto, G. (2010). O aluno com deficiência intelectual na sala de aula: considerações da perspectiva histórico-cultural. In D. A. Maciel \& S. Barbato (Eds.), Desenvolvimento humano, educação e inclusão escolar (pp. 205-220). Brasília: Editora UnB.

Silva, D. N. H., Sirgado, A. P., \& Tavira, L. V. (2012). Memória, narrativa e identidade profissional: analisando memoriais docentes. Cad. Cades, 32(88), 263-283.

Silva, J. da, \& Tavares, H. M. (2009). A atuação pedagógica docente na inclusão de crianças com deficiência no ensino fundamental. Revista da Católica,1(1), 70-86.

Silva, M. M. (2008). A saúde mental e a fabricação da normalidade: uma crítica aos excessos do ideal normalizador a partir das obras de Foucault e Canguilhem. Interação em Psicologia, 12(1), 141-150.

Silva, O. M. (1986). A Época Ignorada: A Pessoa Deficiente na História do Mundo de Ontem e de Hoje. Caderno Cedes.

Silveira, K. A. et al. (2012). Concepções de profissionais sobre inclusão escolar e interações em ambientes inclusivos: uma revisão da literatura [Edição especial]. Revista Brasileira, 18(4), 695-708.

Silveira, S. M. P. (2012). Inclusão escolar e mudanças na escola: a experiência de uma escola pública de Fortaleza. XVI ENDIPE, UNICAMP, Livro 1 (p. 003342). Campinas: Junqueira \& Marin Editores.

Smolka, A. L. B. (2000). A memória em questão: uma perspectiva histórico-cultural. Educação \& Sociedade, (70).

Smolka, A. L. B. (2006). Experiência e discurso como lugares de memória: a escola e a produção de lugares comuns. Pro-Posições, 7(2), 99-118.

Souza, M. L. de (2007). A concepção e o atendimento escolar destinado ao as pessoas com deficiência intelectual: um estudo dos arquivos brasileiros de higiene mental (1925-1947) (Dissertação de mestrado). Universidade de Maringá, Maringá, Brasil.

Souza, V. L. P. de (2013). Alunos com Deficiência Intelectual elou Múltipla Deficiência Inclusão Social. Recuperado em 13 setembro 2017, de http://deficinciaintelectual.blogspot.com.br/2013/10/deficiencia-intelectual-aamr.html.

Tedde, S. (2012). Crianças com deficiência intelectual: a aprendizagem e a inclusão (Dissertação de mestrado). Centro Universitário Salesiano de São Paulo, Americana, Brasil. 
Teles, S. M. (2010). O professor no processo de inclusão de alunos com deficiência intelectual: um estudo sobre os significados construídos no fazer pedagógico (Dissertação de mestrado). Universidade de Brasília, Brasília, Brasil.

Toledo, E. H. de, \& Martins, J. B. (2009). A atuação do professor diante do processo de inclusão e as contribuições de Vigotsky. IX Congresso Nacional de Educação - EDUCERE e III Encontro Sul Brasileiro de Psicopedagogia. PUCPR, Curitiba.

Tunes, E., \& Bartholo, R. (2010). Nos limites da ação: preconceito, inclusão e deficiência. São Carlos: EdUFSCar.

Tunes, E., Souza, J. A. de, \& Rangel, R. B. (1996). Identificando concepções relacionadas à prática com o as pessoas com deficiência intelectual. Revista Brasileira de Educação Especial, 2(4), 7-18.

Veltrone, A. A. (2011). Inclusão escolar do aluno com deficiência intelectual no Estado de São Paulo: identificação e caracterização (Tese de doutorado). Universidade Federal de São Carlos, São Carlos, Brasil.

Veltrone, A. A., \& Mendes, E. G. (2007). Diretrizes e desafios na formação inicial e continuada de professores para a inclusão escolar. IX Congresso Estadual Paulista sobre formação de educadores - UNESP - Universidade Estadual Paulista - Pró-Reitoria de Graduação.

Vigotski, L. S. (1929-2000). Lev S. Vigotski: Manuscrito de 1929.Educação \& Sociedade, (71).

Vigotski, L. S. (1934-2012). Obras Escogidas - V: Fundamentos de defectologia. Madrid: Machado Grupo de Distribución.

Vigotski, L. S. (1984-2007). A formação social da mente: o desenvolvimento dos processos psicológicos superiores (7a ed.). São Paulo: Martins Fontes.

Vigotski, L. S. (1996). Teoria e método em Psicologia. São Paulo: Martins Fontes.

Vigotski, L. S. (2008). A formação social da mente. São Paulo: Martins Fontes. 
Apêndice e Anexos

\section{Apêndice A: Roteiro das entrevistas semiestruturada}

a) Identificação
Nome
Endereço
Idade

Tempo de docência e tempo de docência na inclusão

Em qual regional trabalhou

Formação (graduação e continuada)

b) Pergunta geral: Por que você se tornou professor (a)?

Perguntas específicas sobre inclusão:

O começo - Qual e quando foi a sua primeira experiência com aluno com deficiência intelectual incluído?

Nesta época, quando você se deparou com o primeiro aluno com desenvolvimento peculiar, você participava de algum debate sobre o tema? Tinha feito algum curso, palestra, workshop? Quais?

Se positivo, como esses cursos te ajudaram? Quais conceitos eles ensinaram que foram marcantes para você?

Quais desafios pedagógicos esses alunos traziam para você? Como você fazia para ensiná-lo? Quais estratégias pedagógicas você teve que desenvolver?

c) As políticas de inclusão -o meio

Quando o debate sobre inclusão começou a ocorrer na rede?

Como ele ocorreu?

Tinha cursos, palestras etc.? Ou você procurava por iniciativa própria? 
Quais eram os conteúdos e conceitos mais difundidos nestas atividades de formação continuada?

O que esses conteúdos afetaram na sua dinâmica profissional?

Conte-nos um exemplo ou uma situação.

Quais foram as políticas implementadas pela rede, no que tange à inclusão?

De que maneira elas afetaram o cotidiano escolar? E a sua prática pedagógica? (Permaneceu a mesma ou foi alterada)?

d) Inclusão - as reflexões finais.

Fazendo uma avaliação da sua trajetória profissional, qual é a sua posição sobre a inclusão?

Quais aspectos são positivos? Quais negativos?

Você acredita que a inclusão dá certo?

Atinge aos objetivos educacionais?

Se você pudesse mudar algo na política de inclusão, o que você faria? 


\section{Universidade de Brasília}

Instituto de Psicologia/IP

Programa de Pós-Graduação em Processos de Desenvolvimento Humano e Saúde

Área de Concentração: Desenvolvimento Humano e Educação

Linha de Pesquisa: Processos Educativos e Psicologia Escolar

\section{Termo de Consentimento Livre e Esclarecido}

\section{Termo de Consentimento Livre e Esclarecido aos Professores}

Você está sendo convidado (a) a participar da pesquisa "Análises docentes e o processo histórico de inclusão do aluno com deficiência intelectual na rede pública de ensino do Distrito Federal - os últimos vinte anos", sob a responsabilidade de Soraya Carvalho Pereira Rocha, aluna de mestrado da Universidade de Brasília. O objetivo principal desta pesquisa é analisar as narrativas de professores da rede pública de ensino no Distrito Federal sobre o processo de inclusão dos alunos com deficiência intelectual (implementado nos últimos vinte anos) e os desafios pedagógicos dele decorrentes. Sua participação é voluntária e livre de qualquer remuneração. Você é livre para recusar-se a participar, retirar seu consentimento ou interromper sua participação a qualquer momento. A recusa em participar não irá acarretar qualquer penalidade ou perda de benefícios. Sua participação na pesquisa não traz nenhum risco, porém a entrevista será áudio-gravada e seu conteúdo será integralmente transcrito para posterior análise. Sua participação nesta pesquisa consistirá de entrevistas semiestruturadas, individuais, contendo perguntas amplas e gerais sobre questões da inclusão, deficiência intelectual, políticas públicas sobre inclusão, de modo a enfatizar as concepções docentes sobre o processo inclusivo. A partir das respostas poderão ser adicionadas novas perguntas permitindo que possam narrar suas ideias de forma livre, para possibilitar ao pesquisador um melhor entendimento sobre a temática abordada. O material gravado e transcrito ficará sob a guarda da pesquisadora, que se comprometerá a não divulgá-lo em outros meios. Ele somente será usado para a referida pesquisa. É garantido o sigilo e privacidade das informações obtidas, tanto por meio das entrevistas, como as gravações e de possíveis divulgações ou publicações futuras. Esta pesquisa trará benefícios para os participantes, pois estes contribuirão para trazer e ampliar, no 
campo da psicologia e educação, esclarecimentos e bases de dados para pesquisas sobre a inclusão escolar de alunos com deficiência intelectual. Se você tiver qualquer dúvida em relação à pesquisa, pode me contatar por meio do telefone (61) 98495-4226 ou pelo e-mail sorayacprocha@gmail.com. A equipe de pesquisa garante que os resultados do estudo serão devolvidos aos participantes por meio de um relatório ao (à) professor (a) sobre a temática estudada com base nos resultados construídos, podendo ser publicados posteriormente na comunidade científica. Este projeto foi aprovado pelo Comitê de Ética em Pesquisa da Faculdade de Medicina da Universidade de Brasília. As dúvidas com relação à assinatura do TCLE ou os direitos do sujeito da pesquisa podem ser obtidos através do telefone: (61) 31071918 ou do e-mail cepfm@unb.br.

Este documento foi elaborado em duas vias, sendo a primeira página rubricada e a segunda assinada por mim (pesquisadora) e por você. Uma das vias ficará com o(a) pesquisador(a) responsável pela pesquisa $\mathrm{e}$ a outra com $\mathrm{o}$ senhor(a). de de 2016. 
Anexo B: Parecer consubstanciado CEP

\section{DADOS DO PROJETO DE PESQUISA}

Título da Pesquisa: NARRATIVAS DOCENTES E O PROCESSO HISTÓRICO DE INCLUSÃO DO ALUNO COM DEFICIÊNCIA INTELECTUAL NA REDE PÚBLICA DO DISTRITO FEDERAL ¿ OS ÚLTIMOS VINTE ANOS

Pesquisador: Soraya Carvalho Pereira Rocha

Área Temática:

Versão: 3

CAAE: 56701116.4 .0000 .5558

Instituição Proponente: Instituto de Psicologia -UNB

Patrocinador Principal: Financiamento Próprio

\section{DADOS DO PARECER}

Número do Parecer: 1.793 .971

\section{Apresentação do Projeto:}

Vide parecer anterior.

\section{Objetivo da Pesquisa:}

Vide parecer anterior.

\section{Avaliação dos Riscos e Benefícios:}

Vide parecer anterior.

\section{Comentários e Considerações sobre a Pesquisa:}

Foi anexado pela pesquisadora responsável uma carta em papel não timbrado do gestor da Escola Classe 64 da Ceilândia-DF, senhor Hudson Barbosa Campos, em que refere estar de acordo a realização da pesquisa em suas dependências. Também foi anexado o TCLE corrigido que se encontra adequado.

\section{Considerações sobre os Termos de apresentação obrigatória:}

Foram incluídos no processo o TCLE; o projeto preenchido na Plataforma Brasil e carta do gestor da Escola Classe 64 da Ceilândia-DF.

\section{Conclusões ou Pendências e Lista de Inadequações:}

Considero que todas as pendências foram resolvidas e o projeto poderá ser aprovado, salvo melhor juízo dos membros do CEP-FM.

\section{Considerações Finais a critério do CEP:}

O presente projeto foi apresentado na 9a Reunião Ordinária do CEP-FM.

Após discussão do parecer emitido pelo relator (a), o projeto foi aprovado por unanimidade. 
Este parecer foi elaborado baseado nos documentos abaixo relacionados:

\begin{tabular}{|c|c|c|c|c|}
\hline Tipo Documento & Arquivo & Postagem & Autor & Situaçã \\
\hline $\begin{array}{l}\text { Informações } \\
\text { do Proieto }\end{array}$ & $\begin{array}{l}\text { PB INFORMACCÕES BÁSICAS DO P } \\
\text { ROJETO 719678.0df }\end{array}$ & $\begin{array}{l}02 / 09 / 2016 \\
17: 03: 53\end{array}$ & & Aceito \\
\hline $\begin{array}{l}\text { TCLE / Termos de } \\
\text { Assentimento / } \\
\text { Justificativa de } \\
\text { Ausência }\end{array}$ & termo livre e esclarecido.pdf & $\begin{array}{l}\text { 02/09/2016 } \\
17: 02: 10\end{array}$ & $\begin{array}{l}\text { Soraya Carvalho } \\
\text { Pereira Rocha }\end{array}$ & Aceito \\
\hline Outros & carta aceite instituicao pesquisa.pdf & $\begin{array}{l}02 / 09 / 2016 \\
15: 49: 52\end{array}$ & $\begin{array}{l}\text { Sorava Carvalho } \\
\text { Pereira Rocha }\end{array}$ & Aceito \\
\hline Outros & Roteiro entrevistas.pdf & $\begin{array}{l}08 / 08 / 2016 \\
18: 41: 18\end{array}$ & $\begin{array}{l}\text { Sorava Carvalho } \\
\text { Pereira Rocha }\end{array}$ & Aceito \\
\hline Outros & $\begin{array}{l}\text { Curriculo Lattes Daniele Nunes Henr } \\
\text { ue Silva.pdf }\end{array}$ & $\begin{array}{l}08 / 08 / 2016 \\
18: 40: 26\end{array}$ & $\begin{array}{l}\text { Soraya Carvalho } \\
\text { Pereira Rocha }\end{array}$ & Aceito \\
\hline Outros & $\begin{array}{l}\text { Curriculo Lattes Soraya Carvalho Per } \\
\text { eira Rocha.pdf }\end{array}$ & $\begin{array}{l}08 / 08 / 2016 \\
18: 39: 33\end{array}$ & $\begin{array}{l}\text { Soraya Carvalho } \\
\text { Pereira Rocha }\end{array}$ & Aceito \\
\hline Outros & $\begin{array}{l}\text { Encaminhamento de projeto Soraya } \\
\text { ocha.pdf }\end{array}$ & $\begin{array}{l}\text { 18/05/2016 } \\
18: 01: 53\end{array}$ & $\begin{array}{l}\text { Soraya Carvalho } \\
\text { Pereira Rocha }\end{array}$ & Aceito \\
\hline $\begin{array}{l}\text { Declaração de } \\
\text { Pesquisadores }\end{array}$ & $\begin{array}{l}\text { Declaracao de responsabilidade Sora } \\
\text { a Rocha.pdf }\end{array}$ & $\begin{array}{l}18 / 05 / 2016 \\
16: 45: 45\end{array}$ & $\begin{array}{l}\text { Soraya Carvalho } \\
\text { Pereira Rocha }\end{array}$ & Aceito \\
\hline $\begin{array}{l}\text { Declaração de } \\
\text { Instituição e } \\
\text { Infraestrutura }\end{array}$ & $\begin{array}{l}\text { Termo de concordancia Institucional } \\
\text { oraya_Rocha.pdf }\end{array}$ & $\begin{array}{l}18 / 05 / 2016 \\
16: 43: 39\end{array}$ & $\begin{array}{l}\text { Soraya Carvalho } \\
\text { Pereira Rocha }\end{array}$ & Aceito \\
\hline Folha de Rosto & Folha de rosto Soraya Rocha.pdf & $\begin{array}{l}\text { 18/05/2016 } \\
16: 40: 14\end{array}$ & $\begin{array}{l}\text { Soraya Carvalho } \\
\text { Pereira Rocha }\end{array}$ & Aceito \\
\hline $\begin{array}{l}\text { Proieto Detalhado } \\
\text { Brochura } \\
\text { Investigador }\end{array}$ & $\begin{array}{l}\text { Proieto de pesquisa Sorava Rocha.p } \\
f\end{array}$ & $\begin{array}{l}16 / 05 / 2016 \\
13: 57: 38\end{array}$ & $\begin{array}{l}\text { Sorava Carvalho } \\
\text { Pereira Rocha }\end{array}$ & Aceito \\
\hline
\end{tabular}

\section{Situação do Parecer:}

Aprovado

\section{Necessita Apreciação da CONEP:}

Não

BRASILIA, 26 de Outubro de 2016

\section{Assinado por:}

Florêncio Figueiredo Cavalcanti Neto (Coordenador) 